\title{
FLORÍSTICA E FITOSSOCIOLOGIA DE DUAS UNIDADES DO MOSAICO FLORESTAL DA ESTAÇÃO ECOLÓGICA DOS CAETETUS-FLORESTA ESTACIONAL SEMIDECIDUAL, GÁLIA-SP
}

Geraldo Antônio Daher Corrêa Franco

Biólogo

Orientador: Prof. Dr. RICARDO RIBEIRO RODRIGUES

Dissertação apresentada à Escola Superior de

Agricultura "Luiz de Queiroz", Universidade de São

Paulo, para obtenção do Título de Mestre em Ciências, Área de Concentração: Ciências Florestais.

PIRACICABA

Estado de São Paulo - Brasil

Fevereiro - 2002 
FRANCO, Geraldo Antonio Daher Corrêa. Florística e fitossociologia de duas unidades do mosaico florestal da Estação Ecológica dos Caetetus - Floresta Estacional Semidecidual, Gália - SP.

\section{CORRIGENDA}

Incluir na página 40 , itens 91 b. e $92 a$. e b.:

\begin{tabular}{|l|l|l|l|l|}
\hline & b. & $\begin{array}{l}\text { Folhas ovais, de 3 a } 5 \mathrm{~cm} \text { de } \\
\text { comprimento, ápice agudo, } \\
\text { peciolo menor que 1 cm } \\
\text { (geralmente } 5 \mathrm{~mm} \text { ) }\end{array}$ & Eugenia sp 2 & \\
\hline 92 & a. & Bordo ondulado & $\begin{array}{l}\text { Campomanesia rhombea } \\
\text { Campomanesia } \\
\text { xanthocarpa }\end{array}$ & \\
\hline & b. & Bordo plano &
\end{tabular}

Incluir na página 41 , item 103b.:

\begin{tabular}{|l|l|l|l|l|}
\hline b. & $\begin{array}{l}\text { Limbo com 6 a } 9 \mathrm{~cm} \text { de } \\
\text { comprimento por } 2 \text { a } 4 \mathrm{~cm} \text { de } \\
\text { largura }\end{array}$ & Myrtaceae sp 1 &
\end{tabular}

Incluir na página 42 , itens $104 a$. e b.:

\begin{tabular}{|l|l|l|l|l|}
\hline 104 & a. & $\begin{array}{l}\text { Folhas de } 5 \text { a } 15 \mathrm{~cm} \mathrm{de} \\
\text { comprimento por } 2 \text { a } 6 \mathrm{~cm} \text { de } \\
\text { largura }\end{array}$ & Eugenia florida \\
\hline b. & $\begin{array}{l}\text { Folhas de } 3 \text { a } 7 \mathrm{~cm} \mathrm{de} \\
\text { comprimento por } 0,5 \text { a } 1,5 \mathrm{~cm} \\
\text { de largura }\end{array}$ & Eugenia ramboi \\
\hline
\end{tabular}

Incluir na página 44, item 131b.:

\begin{tabular}{|l|l|l|l|}
\hline b. & $\begin{array}{l}\text { Ramos jovens cilíndricos, folhas } \\
\text { elíptico-lanceoladas, ápice } \\
\text { agudo, base aguda, 10 a } 20 \mathrm{~cm} \\
\text { de comprimento, } 5 \text { a } 8 \mathrm{~cm} \text { de } \\
\text { largura }\end{array}$ & Colubrina glandulosa &
\end{tabular} \mid


Anular página 47.

Incluir na página 48 , itens $149 \mathrm{~b}$. a $158 \mathrm{~b}$.:

\begin{tabular}{|c|c|c|c|c|}
\hline & b. & Ramos glabros & & 150 \\
\hline \multirow[t]{2}{*}{150} & a. & $\begin{array}{l}\text { Presença de estrias escuras na } \\
\text { face inferior do limbo }\end{array}$ & & 151 \\
\hline & b. & $\begin{array}{l}\text { Presença de pontuações na face } \\
\text { inferior do limbo }\end{array}$ & & 152 \\
\hline \multirow[t]{2}{*}{151} & a. & $\begin{array}{l}\text { Estrias enegrecidas na face } \\
\text { inferior do limbo }\end{array}$ & Ardisia sp & \\
\hline & b. & $\begin{array}{l}\text { Estrias pardas na face inferior do } \\
\text { limbo }\end{array}$ & Dendropanax cuneatum & \\
\hline \multirow[t]{2}{*}{152} & a. & Base reflexa & Rapanea umbelata & \\
\hline & b. & Base não reflexa & Rapanea sp & \\
\hline \multirow[t]{2}{*}{153} & a. & $\begin{array}{l}\text { Ramos jovens nitidamente } \\
\text { pilosos }\end{array}$ & & 154 \\
\hline & b. & Ramos jovens glabros & & 155 \\
\hline \multirow[t]{2}{*}{154} & a. & $\begin{array}{l}\text { Pilosidade ferrugínea, } 10 \text { a } 20 \\
\mathrm{~cm} \text { comprimento das folhas, } 5 \text { a } \\
9 \mathrm{~cm} \text { largura das folhas }\end{array}$ & Ficus $s p 2$ & \\
\hline & b. & $\begin{array}{l}\text { Pilosidade esbranquiçada, } 4 \text { a } 10 \\
\mathrm{~cm} \text { comprimento das folhas, } 2,5 \\
\mathrm{a} 4 \mathrm{~cm} \text { largura das folhas }\end{array}$ & Ficus sp 1 & \\
\hline \multirow[t]{2}{*}{155} & a. & Base cordada & Ficus guaranitica & \\
\hline & b. & Base não cordada & & 156 \\
\hline \multirow[t]{2}{*}{156} & a. & $\begin{array}{l}\text { Ápice agudo, estípulas com } 4 \text { a } 8 \\
\text { cm de comprimento }\end{array}$ & Ficus insipida & \\
\hline & b. & $\begin{array}{l}\text { Ápice obtuso a arredondado, } \\
\text { com } 1 \text { a } 2 \mathrm{~cm} \text { de comprimento }\end{array}$ & & 157 \\
\hline \multirow[t]{2}{*}{157} & a. & $\begin{array}{l}\text { Folhas obovadas a elípticas, } \\
\text { ápice arredondado, base } \\
\text { arredondada, ramos terminais } \\
\text { com cerca de } 1 \mathrm{~cm} \text { de diâmetro, } \\
\text { peciolos achatados, } 15 \text { a } 25 \mathrm{~cm} \\
\text { de comprimento, } 5 \text { a } 10 \mathrm{~cm} \text { de } \\
\text { largura }\end{array}$ & Ficus obtusifolia & \\
\hline & b. & $\begin{array}{l}\text { Folhas elipticas, ápice obtuso, } \\
\text { base arredondada, } 10 \text { a } 20 \mathrm{~cm} \\
\text { de comprimento, } 3 \text { a } 8 \mathrm{~cm} \text { de } \\
\text { larqura }\end{array}$ & Ficus enormis & \\
\hline \multirow[t]{2}{*}{158} & a. & $\begin{array}{l}\begin{array}{l}\text { Margem não inteira (serreada, } \\
\text { denteada, etc) }\end{array} \\
\end{array}$ & & 159 \\
\hline & b. & Margem inteira (lisa) & & 185 \\
\hline
\end{tabular}




\section{Dados Internacionais de Catalogação na Publicação (CIP) DIVISÃO DE BIBLIOTECA E DOCUMENTAÇÃO - ESALQ/USP}

\section{Franco, Geraldo Antônio Daher Corrêa}

Florística e fitossociologia de duas unidades do mosaico florestal da estação ecológica dos caetetus-floresta estacional semidecidual, Gália-SP / Geraldo Antônio Daher Corrêa Franco. - - Piracicaba, 2002.

$95 \mathrm{p}$. : il.

Dissertação (mestrado) - - Escola Superior de Agricultura Luiz de Queiroz, 2002. Bibliografia.

1. Comunidade vegetais 2. Flora 3. Floresta 4. Plantas (Identificação) I. Título

$\operatorname{CDD} 634.9$ 
Dedico à minha esposa Cristina este trabalho. 


\section{AGRADECIMENTOS}

Ao Ricardo, pela orientação e a amizade de sempre.

À Giselda, à Marinez e ao Furlan, pela amizade e ajuda em todos os momentos e pelo prazer de trabalhar com uma super-equipe.

Ao Baitello, pelo apoio ao longo deste trabalho e pela identificação das Lauraceae.

À Ivete e ao Ciro, pela indispensável ajuda desde o início deste trabalho. Ao Kronka e ao Marquinhos, pelo fornecimento dos dados cartográficos. Ao João Aurélio e ao Osny, pela identificação das Meliaceae e Myrtaceae, respectivamente.

À Isabel Mattos e ao Dimas, pelas dicas na classificação dos tipos vegetacionais e pela caracterização geomorfológica da área. Ao Márcio Rossi, ao Rui Pfeiffer, ao Hugo de Souza Dias, ao Nabo, pela indispensável ajuda nos dados pedológicos.

À Rejane, à Rosangela, ao Alcebíades, pela ajuda nos trabalhos com os dados. À Median e à Regma, pela amizade e acolhida.

Ao Frederico, ao Marcio Sztutman, ao Corgo, à Adriana Rozza e ao Vicente, pelo importantíssimo auxílio nas análises fitossociológicas.

Ao Gnomo, Alessanda e à Neném, pela amizade e disposição de sempre ajudar.

Ao Sergius Gandolfi, pela leitura e importantes contribuições para este trabalho. À Célia, ao Teodoro, ao Beto e ao Aparecido, pelo apoio no dia a dia dos trabalhos. 
À Sandra e ao Demétrio pela ajuda na hora certa.

Ao Wilson Contieri, pelo apoio indispensável para a execução deste trabalho.

Ao Carlos, meu amigo e cunhado, pelos papos e estímulo.

Aos meus pais, in memoriam, que sempre me deram o apoio necessário.

À minha esposa Cristina, por tudo. 


\section{SUMÁRIO}

Página

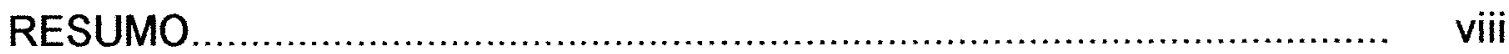

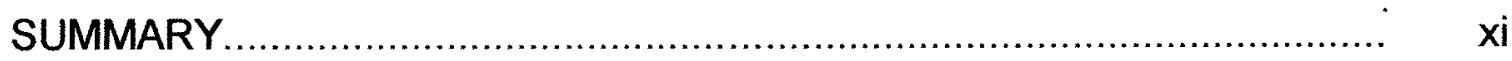

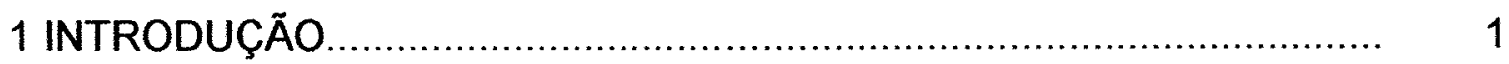

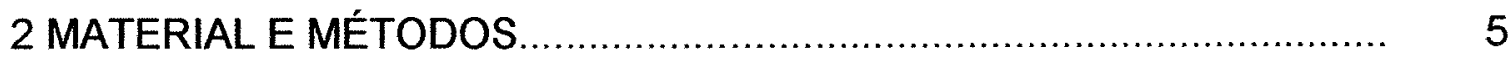

2.1 Descrição geral da área................................................................ 5

2.2 Descrição geral da vegetação...................................................... 7

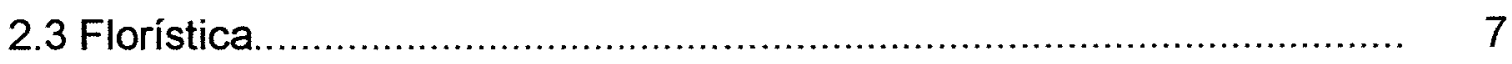

2.4 Chave baseada em caracteres vegetativos ......................................... 8

2.5 Fitossociologia de duas unidades do mosaico ambiental da E. E. dos

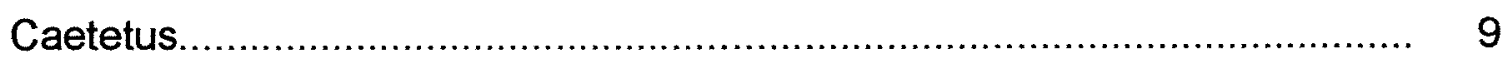

2.5.1 Escolha dos trechos para caracterização fitossociológica.................... 9

2.5.2 Método de amostragem de vegetação........................................... 11

2.5.3 Análise dos dados.................................................................... 11

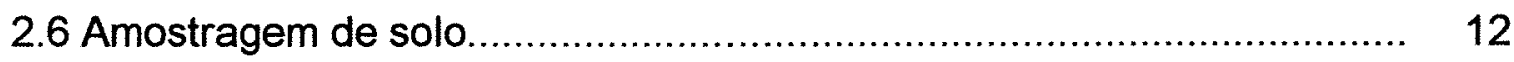

2.6.1 Fórmulas e definições dos parâmetros químicos do solo.................... 13

3 RESULTADOS E DISCUSSÄO ........................................................ 14

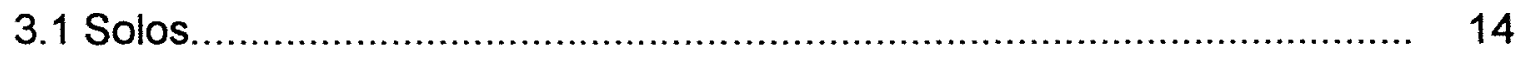

3.1.1 Caracterização da área A....................................................... 14

3.1.2 Caracterização da área B........................................................... 14

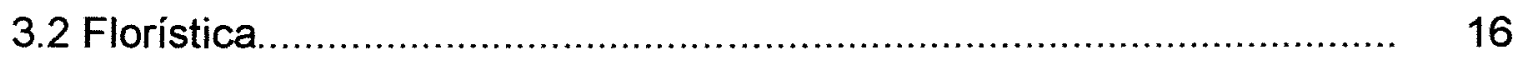

3.3 Chave dicotômica baseada em caracteres vegetativos........................ 30

3.4 Observações e recomendações para o uso da chave........................... 58

3.5 Fitossociologia de dois trechos de floresta da E. E. dos Caetetus....... 59 


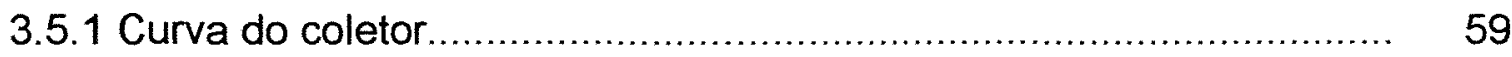

3.5.2 Distribuição diamétrica da comunidade.......................................... 60

3.5.3 Parâmetros fitossociológicos .................................................. 61

3.6 Similaridade e estratificação entre os trechos de floresta................... 76

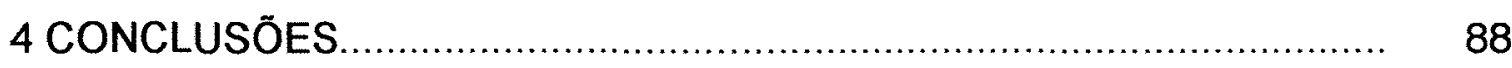

REFERÊNCIAS BIBLIOGRÁFICAS................................................. 90 


\title{
FLORISTICA E FITOSSOCIOLOGIA DE DUAS UNIDADES DO MOSAICO FLORESTAL DA ESTAÇÃO ECOLÓGICA DOS CAETETUS- FLORESTA ESTACIONAL SEMIDECIDUAL, GÁLIA-SP
}

\author{
Autor: GERALDO ANTONIO DAHER CORREAA FRANCO \\ Orientador: Prof. Dr. RICARDO RIBEIRO RODRIGUES
}

\section{RESUMO}

A Estação Ecológica dos Caetetus é um dos últimos remanescentes significativos de floresta estacional semidecidual no planalto ocidental paulista e contém uma amostra representativa da flora original da região. Neste trabalho apresentamos a relação das espécies arbóreas encontradas no interior da Estação, cujo material foi coletado em excursões que abrangeram todas as fitofisionomias do mosaico ambiental e sucessional da floresta. Além da relação das espécies identificadas, elaborou-se também uma chave para identificação das espécies com base em caracteres vegetativos. Foram analisados fitossociologicamente dois trechos de floresta madura correspondente às duas principais unidades do mosaico ambiental, sendo, a primeira, no topo (área A), com solo do tipo Podzólico Vermelho-Amarelo Argiloso Distrófico e a segunda, no baixio (área B), com solo Podzólico Vermelho-Amarelo Arenoso Eutrófico. $\mathrm{Na}$ análise florística foram identificadas 234 espécies arbustivo-arbóreas em 152 gêneros, pertencentes a 57 familias, 
sendo que 133 espécies estão distribuídas em apenas 10 famílias, restando 101 espécies distribuídas em outras 47 familias. $\mathrm{Na}$ análise fitossociológica, as espécies com maior IVI foram: para Área A: Savia dyctiocarpa $(63,94 \%)$; Actinostemon concepcionis (25,02\%); Astronium graveolens (17,39\%); Piptadenia gonoacantha (13,73\%); Croton floribundus (13,39\%); Aspidosperma polyneuron (10,71\%); para Área B: Metrodorea nigra (69,36\%); Savia dyctiocarpa $(57,10 \%)$; Ocotea indecora (21,66\%); Aspidosperma polyneuron (17,65\%); Trichilia catigua $(12,00 \%)$. Destes dados destaca-se que Savia dyctiocarpa possui alto IVI em ambas as áreas. Metrodorea nigra supera Savia dyctiocarpa na área B, devido a suas maiores densidade e freqüência relativas; por outro lado, Metrodorea nigra não está representada na área A. Actinostemon concepcionis, $2^{a}$ classificada na área $A$, ocupa a $37^{\mathrm{a}}$ posição na área $B$, que é ocupada predominantemente neste nicho espacial por Metrodorea nigra. Na área A ocorreram duas espécies pioneiras entre as 10 de maior IVI, Piptadenia gonoacantha e Croton floribundus, (4 $4^{\mathrm{a}}$ e $5^{\mathrm{a}}$ posições respectivamente); na área $B$ a única espécie pioneira entre as 10 mais importantes é Croton floribundus na $8^{a}$ posição. Gallesia integrifólia, com apenas dois indivíduos, possui a $6^{\mathrm{a}}$ maior dominância relativa $(4,80 \%)$ na área $\mathrm{B}$. A amostragem fitossociológica de dois hectares corresponde a 0,09\% da área total da reserva, no entanto amostrou $52,17 \%$ das espécies arbustivo-arbóreas amostradas no levantamento floristico. As espécies dominantes do dossel também estão presentes nos estratos inferiores, mascarando as diferenças florísticas entre os estratos. $O$ índice de Jaccard entre os dois trechos de 1 ha cada foi de $33 \%$, para o dossel foi de $30 \%$, para o subosque foi de $27 \%$; excluindo-se do subosque as espécies de dossel cujos indivíduos jovens estavam presentes, o mesmo índice foi de $18 \%$. Usando também parâmetros quantitativos através da análise de BrayCurtis além do índice de Jaccard, demonstramos que o dossel é qualitativa e quantitativamente mais homogêneo que o subosque. Estas mesmas análises concluem que o subosque das áreas $\mathrm{A}$ e $\mathrm{B}$ são nitidamente diferentes. $\mathrm{Na}$ análise 
geral, tal fato é suficiente para determinar que as florestas das duas áreas apresentam diferenças significativas, apesar de muito próximas espacialmente.

Palavras-chaves: floresta estacional semidecidual, florística, chave de identificação, fitossociologia. 


\title{
FLORISTIC AND PHYTOSSOCIOLOGY OF TWO UNITIES OF THE FORESTAL MOSAIC OF "ESTAÇÃO ECOLÓGICA DOS CAETETUS" - SEMIDECIDUOUS SEASONAL FOREST, GÁLIA, SP.
}

\author{
Author: GERALDO ANTONIO DAHER CORREA FRANCO \\ Adviser: Prof. Dr. RICARDO RIBEIRO RODRIGUES
}

\section{SUMMARY}

Caetetus Ecological Station is one of the last significant remaining areas of Semi-deciduous Seasonal Forest on the Western tableland in the state of São Paulo and contains a representative sample of the original flora of that region. The present paper shows the list of arboreal species found inside the "Estação", whose material was collected on excursions that comprised all phytophysiognomies of the forest's environmental and successional mosaic. Besides the list of identified species, a key to the species' identification was also elaborated based on vegetative characteristics. Two intervals of mature forest, corresponding to the two main unities of the environmental mosaic, were phytosociologically examined, the first of them, on the tableland (area A), with red-yellow podzolic clayey dystrophyc soil and the second one, on the lowland (area B), with red-yellow podzolic clayey euthrophic soil. The floristic analysis identified 234 species in 152 genera, belonging to 57 families; 133 species are distributed in only 10 families, remaining 
101 species distributed in other 47 families. The species with greatest IVI in the phytosociological analysis are: for area A: Savia dyctiocarpa $(63,94 \%)$; Actinostemon concepcionis (25,02\%); Astronium graveolens (17,39\%); Piptadenia gonoacantha (13,73\%); Croton floribundus (13,39\%); Aspidosperma polyneuron $(10,71 \%)$. For area B: Metrodorea nigra $(69,36 \%)$; Savia dyctiocarpa $(57,10 \%)$; Ocotea indecora (21,66\%); Aspidosperma polyneuron (17,65\%); Trichilia catigua $(12,00 \%)$. These data stand out that Savia dyctiocarpa has high IVI in both areas. Metrodorea nigra exceeds Savia dyctiocarpa in area B because of its greater relative density and frequency; on the other hand Metrodorea nigra is not represented in area A. Actinostemon concepcionis, second classification in area A, occupies the $37^{\text {th }}$ position in area $B$, which is preponderantly occupied in this spatial niche by Metrodorea nigra. In area $A$ there are two pioneer species among the ten species with greater IVI, Piptadenia gonoacantha and Croton floribundus ( $4^{\text {th }}$ and $5^{\text {th }}$ position respectively); in area $B$ the only one pioneer species among the 10 most important is Croton floribundus in $8^{\text {th }}$ position. We also emphasize that Gallesia integrifolia, has the $6^{\text {th }}$ greater relative dominance $(4,80 \%)$ in area $B$. The sample of two hectare for the phytosociological survey corresponds to $0,09 \%$ of the whole reservation's area, yet it showed $52,17 \%$ of the reservation's bush-arboreal species indicated by the floristic survey. The canopy's dominant species are also present in the lower strata, disguising the floristic differences between the strata. Jaccard's Index between both intervals of 1 ha each one was of 33\%; the same Index was of $30 \%$ for the canopy and of $27 \%$ for the lower stratum; if we exclude from the lower stratum the young individuals of the canopy's species, the same Index was of $18 \%$. Also using quantitative parameters through the Bray-Curtis analysis besides Jaccard's Index, we demonstrate that the canopy is qualitatively and quantitatively more homogeneous than the lower stratum. These same analyses conclude that the lower stratum of both areas A and B are clearly different. In the general analysis this fact is sufficient to determine that the forests of both areas show significant differences although they are spatially very close. 
Key-words: Semi-deciduous Seasonal Forest, floristic, identification key, phytossociology. 


\section{INTRODUÇÃO}

O estado de São Paulo apresentava originalmente cerca de $82 \%$ de sua área cobertos por formações florestais nativas. A partir do século XIX a expansão da cultura cafeeira, a abertura de ferrovias, a pecuária e, atualmente, a urbanização e a industrialização crescentes contribuíram para a redução deste valor para apenas 5\% em 1973 (Vitor, 1975).

A vegetação nativa remanescente no estado de São Paulo constitui-se atualmente de fragmentos com elevado grau de isolamento, a maioria mantida na forma de reservas, estações ecológicas e parques, que estão sob o domínio do poder público, adicionados de pequenas áreas particulares, cuja preservação foi conseqüência das dificuldades para práticas agrícolas (Castanho Filho \& Feijó, 1987).

O interior do estado de São Paulo, bem como parte de Minas Gerais, do Mato Grosso do Sul e de Goiás, oeste do Paraná e de Santa Catarina, estendendo-se até o Rio Grande do Sul, na Bacia do Rio Turvo, era originalmente ocupado por florestas com características fisionômicas semelhantes. Esta floresta, caracterizada pela ausência de coníferas e pela perda parcial das folhas no inverno, recebeu diferentes denominações por diferentes autores, tais como: floresta latifoliada da bacia do Paraná-Uruguai (Veloso, 1962), mata atlântica de interior (Rizzini, 1979), floresta latifoliada semicaducifólia (Leitão Filho, 1982), floresta tropical latifoliada mesofítica perenifólia de terra firme (Eiten, 1983), floresta mesófila semidecídua, adaptado de (Rizzini, 1963) e floresta estacional semidecidual (IBGE, 1993). 
Esta vegetação, juntamente com a floresta ombrófila densa (da encosta atlântica) e a floresta ombrófila mista (mata de araucária), compõe o denominado domínio da mata atlântica, que, no território nacional, tem a área delimitada e protegida pelo Decreto 750 , de 10 de fevereiro de 1993, que proibe o corte, a exploração e a supressão da Mata Atlântica.

Os estudos da flora e estrutura destas florestas são relativamente recentes e concentrados nas duas últimas décadas (Schlitter et al., 1995).

A primeira publicação da aplicação de métodos fitossociológicos em formações florestais no estado foi feita por Gibbs \& Leitão Filho (1978), quando da avaliação da estrutura de uma floresta de galeria no município de Mogi-Guaçu. Em 1979 Martins (1991) avaliou a estrutura de floresta residual no município de Santa Rita do Passa Quatro.

Em função do histórico antigo e agressivo de devastação no estado de São Paulo, poucos são os grandes remanescentes florestais neste estado que ainda abrigam a vegetação original. Estes remanescentes, na maioria das vezes, encontram-se protegidos na forma de Unidades de Conservação e grande parte deles já foi objeto de levantamento florístico e/ou fitossociológico, como: Parque Estadual do Morro do Diabo, em Teodoro Sampaio (Baitello et al., 1988, e Schlitter et al., 1995), Parque Estadual Vaçununga, em Santa Rita do Passa Quatro (Martins, 1991), Estação Ecológica de Paulo de Faria (Stranghetti \& Taroda-Ranga, 1998), Estação Ecológica de Mogi-Guaçu (Gibbs et al., 1978), Estação Ecológica de Bauru (Cavassan et al., 1984), Estação Experimental de Marília (Durigan \& Leitão Filho, 1995).

Alguns remanescentes dessa unidade fitogeográfica preservados em propriedades particulares têm sido alvo de estudo, destacandose, pelo grande porte, a Mata da Virgínia, no município de Matão (Rozza, 1997), com mais de dois mil hectares.

Os métodos utilizados foram muito variáveis entre esses trabalhos, especialmente número de unidades amostrais, área das parcelas e 
classes de tamanho para estratificação da comunidade ou formas de vida amostradas. Essa falta de padrão acabou por dificultar a comparação dos resultados obtidos neste diferentes remanescentes florestais.

Ainda assim, apesar das limitações metodológicas, trabalhos recentes têm demonstrado que, embora fisionomicamente semelhantes, a composição florística e a estrutura destes remanescentes de Floresta Estacional Semidecidual são muito variáveis, dependentes do histórico de perturbação das características do ambiente.

As diferenças de solo, umidade, macro e microclima e perturbações têm sido apontadas como principais responsáveis pelas diferenças na composição e estrutura de remanescentes florestais, constituindo, assim, comunidades diferenciadas às vezes em áreas muito próximas, definindo 0 mosaico florestal (Rodrigues \& Nave, 2000). Além disso, a dinâmica da silvigênese confere à floresta uma estrutura em forma de mosaicos menores, ou eco-unidades em diferentes fases de desenvolvimento, decorrentes, principalmente, da formação de clareiras, definindo mosaico sucessional (Gandolfi, 2000).

$\mathrm{Na}$ comparação florística entre 19 áreas remanescentes de Floresta Mesófila e Floresta Ripária, (Salis et al., 1995) concluem que estes fragmentos formam grupos muito heterogêneos. Baixo nível de similaridade entre e dentro das florestas do interior do estado foi constatado também por (Torres, 1989) e (Bertani, et al., 2001) estudando gradiente edáfico e vetecional ciliar contínua, estes concluiram que essas florestas consistem de um mosaico de partes floristicamente distintas, em função da interação complexa de diferentes fatores ambientais.

Na regiāo administrativa de Marilia, onde está situada a Estação Ecológica dos Caetetus, a cobertura florestal remanescente, segundo (Kronka et al., 1993), é inferior a 3\%. A Estação, localizada nos municípios de Gália e Alvinlândia, constitui-se em uma das maiores áreas contínuas representativas da Floresta Estacional Semidecidual que revestia o Planalto Ocidental Paulista. 
Trata-se de uma floresta com trechos em excelente estado de preservação, reunindo espécies arbóreas ameaçadas de extinção pela agressividade do extrativismo nos últimos anos, como o guarantã (Esenbeckia leiocarpa), a peróba-rosa (Aspidosperma polyneuron) e a cabreúva (Myroxylon peruiferum), dentre outras.

Por ser relativamente extensa, com $2.178,84$ ha, e bem preservada, a floresta da Estação Ecológica é capaz de abrigar também muitas espécies de animais, alguns inclusive em processo de extinção, destacando-se o mico-leão-preto (Leonthopithecus chrysopygus).

Dessa forma, o objetivo deste trabalho foi caracterizar a flora da Estação Ecológica dos Caetetus, elaborar chave para identificação das espécies arbustivo-arbórea, assim como a caracterização fitossociológica de dois trechos das principais unidades do mosaico florestal. Conhecer florística e estruturalmente este ecossistema florestal é fundamental para todo e qualquer programa que envolva os objetivos de conservação, manejo e restauração da própria área, de florestas da região e do próprio estado de São Paulo. Os conhecimentos serão também definitivos para subsidiar o Plano de Manejo da E.E. dos Caetetus, que está em fase de elaboração, consubstanciando programas de uso público, de educação ambiental e novos projetos de pesquisa. 


\section{MATERIAL E MÉTODOS}

\subsection{Descrição geral da área}

A Estação Ecológica dos Caetetus possui uma área contínua de 2178,84 ha, situada nos municípios de Gália e Alvinlândia, estado de São Paulo, entre as coordenadas geográficas: $22^{\circ} 41^{\prime}$ e $22^{\circ} 46^{\prime}$ de latitude sul e $49^{\circ} 10^{\prime}$ e $49^{\circ} 16^{\prime}$ de longitude Oeste Gr., dentro da Bacia Hidrográfica do Médio Paranapanema, compreendendo terras entre altitudes de 500 e $680 \mathrm{~m}$ (Figura 1). 

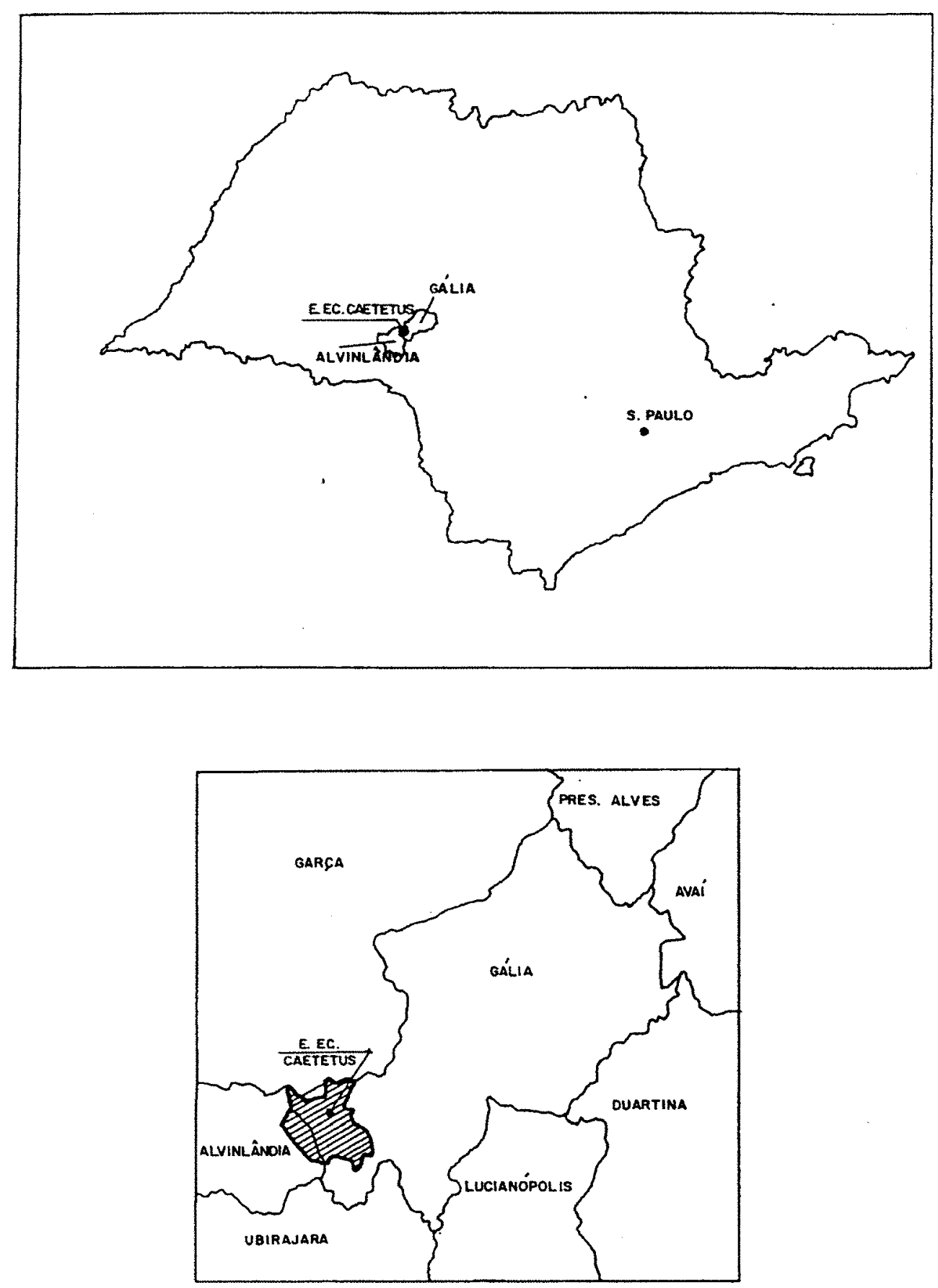

Figura 1 - Localização da Estação Ecológica dos Caetetus 
Predominam na Estação os latossolos de textura média nos topos e os podzólicos abruptos nas vertentes (Mattos et al., 1996). O clima local, segundo a classificação de (Koeppen, 1948), é do tipo Cwa, mesotérmico de inverno seco.

\subsection{Descrição geral da vegetação}

A vegetação da Estação é classificada como Floresta Estacional Semidecidual (IBGE 1993), com grande variação ambiental, compreendendo, por exemplo, remanescentes na condição ribeirinha nas áreas de nascentes, nas encostas íngremes, nas áreas de interflúvio, cada qual com particularidades na caracterização fisiográfica; ocorrem, ainda, variações em função dos estádios sucessionais decorrentes de niveis de perturbação, geralmente associadas à intensidade do efeito de borda.

Este remanescente florestal foi mantido como reserva quando da ocupação agrícola da Fazenda Paraíso, tendo passado a ser propriedade do Estado apenas em 1976. Apesar dos relatos de funcionários de que esta área não sofreu perturbações intensas nas últimas décadas, nossas observações de campo indicam que houve algum tipo de exploração seletiva no passado, dada a expressiva ocorrência de espécies pioneiras, principalmente nos topos. Por outro lado, os baixios apresentam-se mais conservados dadas as dificuldades de acesso nestas áreas. Podemos ainda considerar que há maior efeito de borda nos topos, dada a maior proximidade destes com os limites da Estação.

\subsection{Florística}

A caracterização da flora arbustivo-arbórea ocorrente na $E$. E. dos Caetetus foi feita através de excursões de coleta abrangendo todas as fisionomias da vegetação ao longo de um ano, sendo coletas de cinco dias a cada mês, através da malha de picadas já existente, estradas internas e 
contornando a borda, tendo sido coletado material vegetativo e/ou reprodutivo de todas as espécies arbóreas observadas, para identificação.

O material coletado foi incorporado às coleções dos herbários SPSF, do Instituto Florestal de São Paulo, e ESA, da Escola Superior de Agronomia Luis de Queiroz, e foi processado segundo as técnicas usuais recomendadas por (Fidalgo \& Bononi, 1989).

A identificação das espécies foi feita segundo o sistema de (Cronquist, 1981), com a utilização de chaves analiticas, comparação com material botânico depositado em herbários do Estado de São Paulo e consulta a especialistas.

\subsection{Chave baseada em caracteres vegetativos}

Elaborou-se chave dicotômica, baseada apenas em caracteres vegetativos, priorizando-se ramos e folhas e, eventualmente, acrescentando-se detalhes de tronco, como tipo de casca ou presença de látex, espinhos e odor caracteristico. Os caracteres vegetativos foram elaborados a partir de descrições morfológicas contidas em Floras tais como: Flora Brasiliensis, Flora Neotrópica, Flora Catarinensis, assim como textos de taxonomia geral e morfologia externa de fanerógamas. 
2.5 Fitossociologia de duas unidades do mosaico ambiental da E. E. dos Caetetus

\subsubsection{Escolha dos trechos para caracterização fitossociológica}

Considerando-se os resultados do levantamento de solos e fotografias aéreas verticais da E. E. dos Caetetus, em colorido natural, na escala aproximada de 1:5000, produzidas pela Photon-Imageamento Aéreo em 1994, e informações contidas no Plano de Manejo (Tabanez \& Durigan)' ${ }^{1}$, onde os autores identificam doze tipos vegetacionais, e, após checagens de campo, foram escolhidos dois locais de amostragem mais representativos da floresta classificada como "Vegetação arbórea de porte alto e denso". Estão localizados em diferentes unidades do mosaico ambiental. As duas áreas de amostragem inserem-se no mosaico fitofisionômico na mesma classificação, correspondente aos trechos melhor preservados da floresta. Pelas fotografias aéreas, apesar de estarem em condições fisiográficas distintas (solo e relevo), as duas áreas não apresentam diferenças fitofisionômicas marcantes.

A formação geológica da região é o Arenito Marilia, que vem sendo esculpido pela ação dos rios e da chuva, formando, nas menores cotas altitudinais, vales e baixios e, nas cotas maiores, os topos.

A área (A) localiza-se a uma altitude média de $660 \mathrm{~m}$, sobre solos do Tipo Podzólico Vermelho-Amarelo Argiloso Distrófico e a área (B) localiza-se a uma altitude média de $580 \mathrm{~m}$, sobre solos do Tipo Podzólico Vermelho-Amarelo Arenoso Eutrófico (Tabanez \& Durigan)'.

As áreas de amostragem distam, em linha reta, cerca de $3 \mathrm{~km}$ uma da outra; ambas não apresentam declividade acentuada, $6^{\circ}$ aproximadamente, e não estão em área de influência de cursos d'água e as trilhas de acesso são mínimas, somente para localização das áreas (Figura 2).

'TABANEZ, M.F.; DURIGAN, G. Plano de manejo da Estação Ecológica dos Caetetus. (Não publicado) 


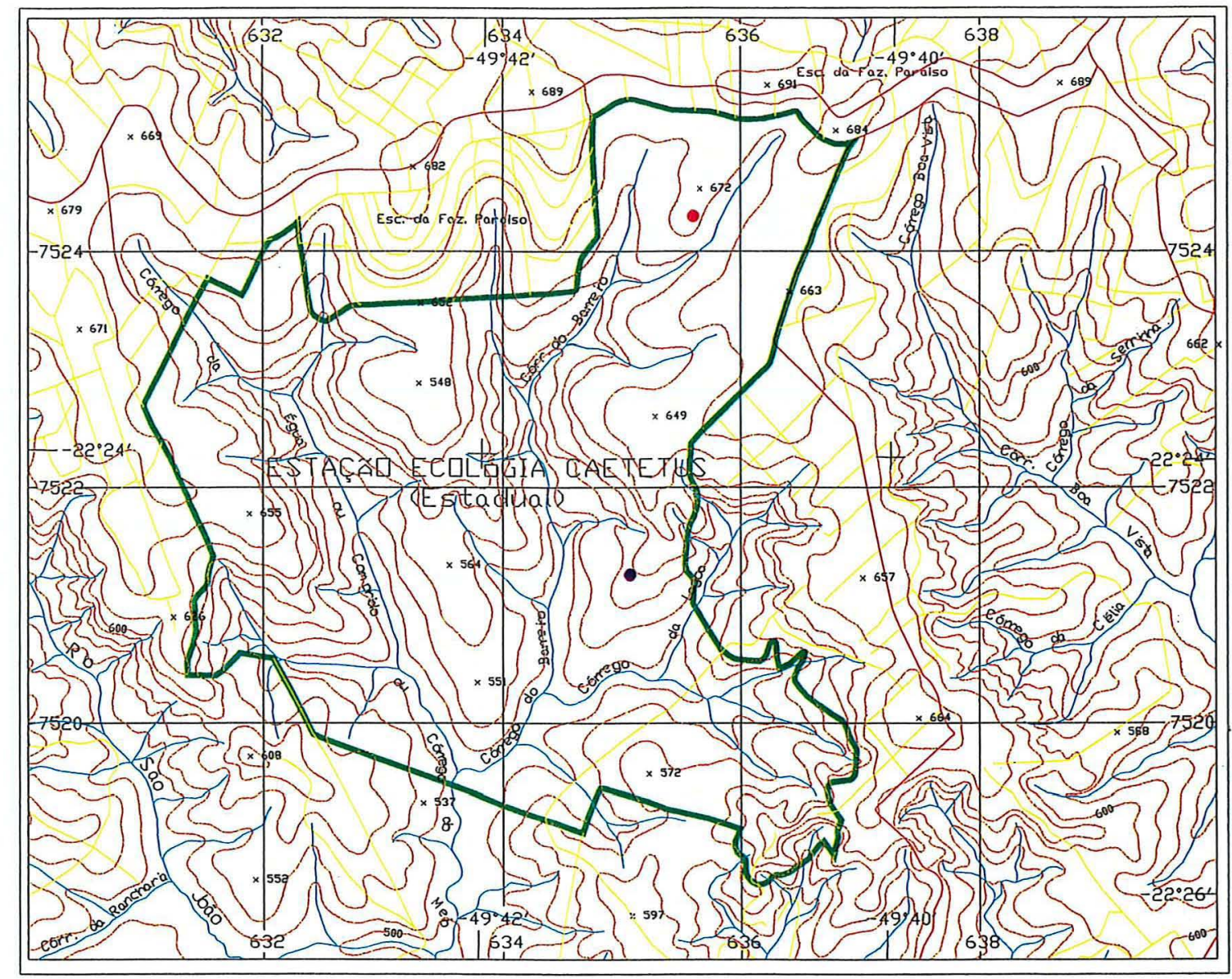

- área a

- áreA b

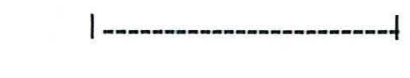

escala: $\quad 2 \mathrm{~km}$

Figura 2 - Mapa detalhado da Estação Ecológica dos Caetetus, Gália, SP. Localização das áreas de amostragem fitossociológica: área $\mathrm{A}$ (topo) e área $\mathrm{B}$ (baixio). Fonte: Folha Cartográfica do IBGE, mapa digitalizado pelo Instituto Florestal, Seção de Manejo e Inventário Florestal 


\subsubsection{Método de amostragem de vegetação}

O método escolhido para a caracterização fitossociológica da floresta nos dois trechos foi o de parcelas contíguas, com um bloco quadrático de 1 ha $(100 \times 100 \mathrm{~m})$ em cada local, subdividido em 100 parcelas de $10 \times 10 \mathrm{~m}$ $\left(100 \mathrm{~m}^{2}\right)$, totalizando $20.000 \mathrm{~m}^{2}$ de área amostral.

Nessas parcelas foram amostrados todos os indivíduos de espécies arbóreas com DAP (diâmetro à altura do peito, medido a 1,30m acima do nivel do solo) maior ou igual a $5 \mathrm{~cm}$; todos os indivíduos foram etiquetados com plaquetas de alumínio numeradas, medidos o DAP, estimada a altura total e colhido o material botânico para identificação.

\subsubsection{Análise dos dados}

A partir dos dados obtidos, foram determinados os parâmetros normalmente calculados em estudos dessa natureza (Müller-Dombois \& Ellemberg 1974), como densidade, freqüência e dominância absolutas e relativas, diversidade e indices compostos (IVI e IVC). Os cálculos e a construção dos dendrogramas foram efetuados através do programa FITOPAC (Shepherd 1995). Para verificar a similaridade florística entre os locais amostrados, foi utilizado o método de classificação, através da utilização dos índices de Jaccard e Bray-Curtis e da construção de dendrogramas baseados na média de grupo (UPGMA). Nas análises de classificação foram utilizados os programas "Coef" e "Cluster" presentes no FITOPAC (Shepherd 1995). Para a construção de dendrogramas, tanto de Jaccard, quanto de Bray-Curtis, as parcelas de $10 \times 10 \mathrm{~m}$ foram agrupadas de $4 \mathrm{em} 4$ para que o número de indivíduos fosse suficiente para uma maior consistência para as análises, assim como para melhorar a visualização didática dos dendrogramas. 
As fórmulas dos índices utilizados na construção dos dendrogramas de similaridade são:

Jaccard

ISJ $=c / a+b+c$

(c) corresponde ao número de espécies comuns às áreas (a) e (b)

(a)corresponde ao número de espécies da área (a)

(b)corresponde ao número de espécies da área (b)

Bray-Curtis

$D(A$ e $B)=\Sigma|X a i-X b i| / \Sigma|X a i+X b i|$

(Xai) corresponde ao número de indivíduos da espécie( $\mathrm{i}$ ) na área ( a )

(Xbi) corresponde ao número de indivíduos da espécie( $\mathrm{i}$ ) na área ( $\mathrm{b}$ )

\subsection{Amostragem de solo}

Em cada hectare dos trechos de floresta para caracterização fitossociológica das áreas $A$ e $B$ foram sorteadas 30 das 100 parcelas para as coletas de solo, nas profundidades $0-5 \mathrm{~cm}, 5-20 \mathrm{~cm}$ e $40-60 \mathrm{~cm}$. Na coleta das amostras foram utilizados pazinha para a primeira profundidade e trado para as duas últimas profundidades. Para a profundidade de $0-5 \mathrm{~cm}$, foram feitas 10 subamostras, das quais, após homogeneizadas no próprio local, foi subtraída uma alíquota para análise. As demais profundidades foram amostradas no centro de cada parcela com o uso de trado pedológico. As análises de solo foram efetuadas no Departamento de Solos da Escola Superior de Agricultura Luiz de Queiroz.

Para a comparação entre os parâmetros edáficos das duas áreas foi realizado o teste $F$ (análise de variância) para os parâmetros físicos (areia, silte e argila) e químicos dos solos estudados (pH, M.O., P, K, Ca, Mg, H, 
$\mathrm{SB}, \mathrm{T}$ e V\%) nas profundidades de $0-5,5-20$ e de 40-60. Essa análise foi feita com o auxilio do software SAS (Statistical Analysis System).

\subsubsection{Fórmulas e Definições dos Parâmetros Químicos do Solo:}

Soma de bases (SB): É a soma do K, Ca e do Mg no solo.

$S B=K+C a+M g$; Complexo de troca de cátions (CTC): É a soma de todos os cátions presentes no solo $(\mathrm{K}+\mathrm{Ca}+\mathrm{Mg}+\mathrm{H}+\mathrm{Al}+\mathrm{Na})$;

$C T C=K+C a+M g+H+A l$; Saturação de bases $(\mathrm{V} \%)$ : É a relação existente entre a soma de bases e a CTC do solo;

$V \%=\frac{S B}{C T C} \times 100 ;$

Quando V\% > 50, então o horizonte é classificado como eutrófico;

Quando V\% < 50, então o horizonte é classificado como distrófico;

Quando $\mathrm{m} \%$ > 50, então o horizonte é classificado como álico;

Saturação de alumínio (m\%): É a relação existente entre o teor de $\mathrm{Al}$ e a $\mathrm{SB}+\mathrm{Al}$ $m \%=\frac{A l}{A l+S B}$ 


\section{RESULTADOS E DISCUSSÃO}

\subsection{Solos}

A análise destes parâmetros confirmou apenas a diferença existente entre estes solos, sendo o solo A um Argilossolo Vermelho - Amarelo distrófico $(\mathrm{V} \%<50)$ e o solo B um Arenoso Vermelho - Amarelo eutrófico $(\mathrm{V} \%>50)$. Verifica-se, também, que os teores de $\mathrm{Ca}$ e $\mathrm{Mg}$ no solo, principalmente nos horizontes superficiais, são bastante distintos entre as áreas estudadas.

\subsubsection{Caracterização da área $A$}

$\mathrm{O}$ solo apresenta uma elevada acidez devido ao baixo $\mathrm{pH}$ e a baixa $\mathrm{V} \%$ do mesmo. $O$ teor de matéria orgânica é relativamente alto, os teores de $P$ são médios e os teores de $\mathrm{K}, \mathrm{Ca}$ e $\mathrm{Mg}$ são bastante elevados. A CTC deste solo é maior que aquela encontrada no solo da área $B$, devido, provavelmente, ao maior teor de argila.

\subsubsection{Caracterização da área B}

$\mathrm{O}$ solo apresenta média acidez devido aos médios valores de $\mathrm{pH}$ e $\mathrm{V} \%$ encontrados neste solo. Os teores de M.O. e P são médios. Os teores de K são baixos e os de $\mathrm{Ca}$ e $\mathrm{Mg}$, muito elevados. $\mathrm{A}$ V\% deste solo é maior que do solo da área $\mathrm{A}$ devido à menor CTC do mesmo. A saturação do complexo catiônico (CTC) pelas bases $\mathrm{K}, \mathrm{Ca}$ e $\mathrm{Mg}$ é mais fácil de ser conseguida. 
Tabela 1. Análise comparativa dos parâmetros físicos e químicos dos solos, nas áreas $A$ e $B$.

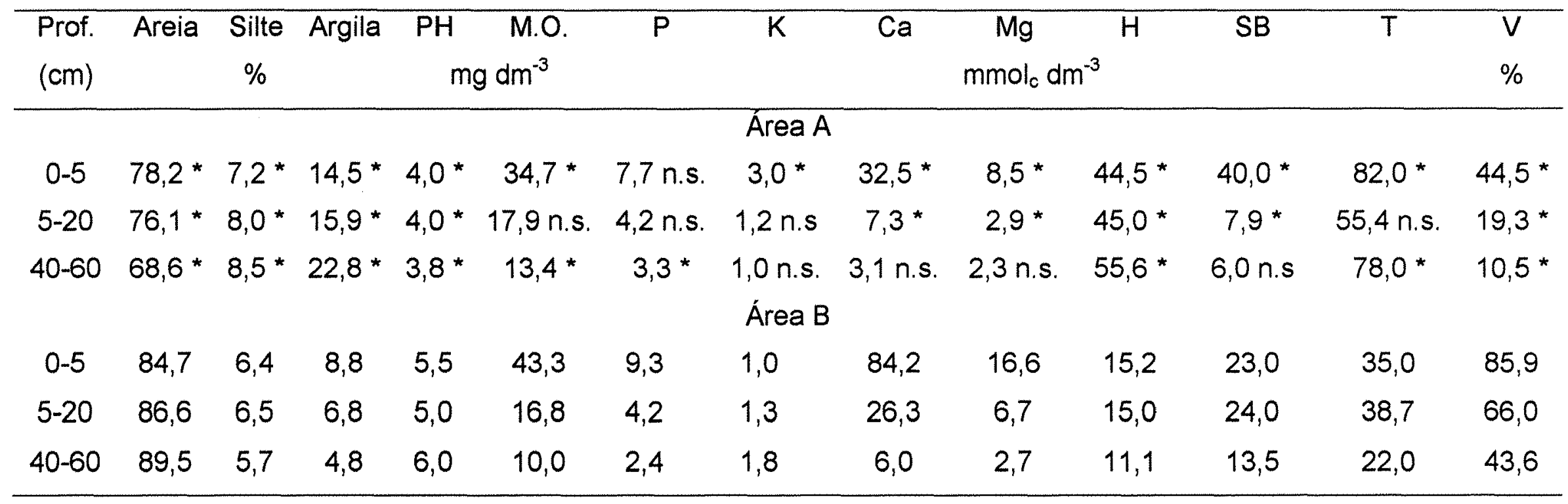

* significativo ao nível de $5 \%$ de probabilidade (as médias entre áreas são diferentes entre si ao nível de $5 \%$ de probabilidade, ou seja, existe $95 \%$ de chance desta hipótese ser verdadeira);

n.s. não significativo. 


\subsection{Florística}

Na caracterização florística da Estação Ecológica dos Caetetus foram identificadas 234 espécies arbustivo-arbóreas (Quadro 1), agrupadas em 152 gêneros, pertencentes a 57 famílias, sendo que 133 espécies estão distribuídas em apenas 10 famílias da seguinte forma: Myrtaceae (28), Euphorbiaceae (17), Rutaceae (17), Fabaceae (12), Lauraceae (12), Melastomataceae (10), Mimosaceae (9), Moraceae (10), Caesalpiniaceae (9) e Meliaceae (9); as outras 101 espécies distribuem-se em outras 47 famílias. O número encontrado de espécies arbóreas superou a todos os levantamentos já efetuados em florestas do oeste paulista, o segundo maior foi o de (Stella et al.)2, com 193 espécies arbustivo-arbóreas no Parque Estadual do Morro do Diabo, utilizando método semelhante a este levantamento. Em trabalho anterior, (Baitello et al., 1988) encontraram 113 espécies arbustivo-arbóreas também no Parque Estadual do Morro do Diabo utilizando-se o método de quadrantes.

A grande riqueza encontrada na Estação Ecológica dos Caetetus deveu-se provavelmente à alta diversidade beta (diversidade de habitats) observada na Estação, assim como topos, baixios, encostas, áreas ciliares, brejos e bordas de mata. O método utilizado permitiu amostrar eficientemente a área, considerando que a diversidade alfa encontrada por (Durigan et al., 2000) em 1 ha de floresta bem preservada no interior da Estação foi inferior à maioria das áreas já estudadas de floresta estacional semidecidual no estado de São Paulo, com $\mathrm{H}^{\circ}$ (índice de diversidade de Shannon) igual a 2,405 para o estrato superior ( $D A P \geq 5 \mathrm{~cm}$ ).

\footnotetext{
${ }^{2}$ STELLA, A.; DURIGAN, G; FRANCO, G.A.D.C. Critérios para seleção de espécies arbóreas prioritárias para conservação na Floresta Estacional Semidecidual. (Não publicado).
} 
O levantamento florístico confirma a classificação da vegetação da Estação como Floresta Estacional Semidecidual, pois verificou-se uma grande coincidência de espécies com outros levantamentos, especialmente para espécies de distribuição geográfica ampla, como Aspidosperma polyneuron, Cedrela fissilis, Parapiptadenia rigida, Chorisia speciosa, Centrolobium tomentosum e muitas outras, características da floresta estacional semidecidual. Por outro lado, verifica-se a ocorrência de espécies mais comuns em outras formações vegetais, como Euterpe edulis (da floresta ombrófila densa), Styrax camporum (do cerrado) e Talauma ovata (floresta paludosa), geralmente associadas a condições particulares de umidade e fertilidade dos solos.

Variaçōes ambientais podem definir diferenças florísticas em localidades com vegetação fisionomicamente semelhante (Baitello et al., 1988). Em vista disso, recomenda-se cautela durante análises comparativas entre fitocenoses envolvendo o número de espécies e a heterogeneidade florística devido às diferenças nos métodos e critérios adotados, devendo ser ressaltadas diferenças quanto ao critério de inclusão, a esforços amostrais, a métodos de amostragem e a históricos de perturbação (César, 1988).

Em uma análise de similaridade florística de remanescentes florestais do estado de São Paulo, (Pinheiro, 2000) indicou uma extensa região no centro do estado, abrangendo parte do planalto ocidental e Cuestas Basalticas onde os remanescentes florestais apresentam uma composição florística muito similar entre si. Estes remanescentes localizam-se nos municípios de Bofete, Botucatu, Jaú, Marilia, Tarumã e Gália (Gabriel, 1990; Nicolini, 1990; Durigan \& Leitão Filho, 1995; Durigan et al., 2000) e correspondem ao chamado grupo florístico mesófilo de baixa altitude mencionado por (Torres et al., 1997), ocupando regiões abaixo de $700 \mathrm{~m}$ de altitude.

Os altos valores de similaridade entre os remanescentes florestais dessa região do estado, constatados por (Pinheiro, 2000), resultaram da proximidade entre as áreas e do uso de métodos amostrais semelhantes, 
atingindo $44,88 \%$ de similaridade entre as fazendas Berrante e São Luís, ambas no município de Tarumã (nestes deve-se dar especial atenção pelo fato de ambos se situarem em áreas ciliares).

Pinheiro (2000) notou também alto grau de similaridade florística entre remanescentes florestais situados em províncias geomorfológicas distintas, como os trabalhos de (Gabriel, 1990) e (Nicolini, 1990) nas matas das Fazendas São João e Santo Antônio nos municípios de Botucatu e Jaú, respectivamente, sendo o primeiro no planalto ocidental paulista e o segundo nas Cuestas Basálticas. Estes apresentam valor do Índice de Similaridade de Jaccard de $60 \%$. No entanto, comparando os trabalhos da Fazenda Oito Pontas (Bofete) com as matas da Fazenda Tarumã, da Estação Experimental de Marília e da Estação Ecológica dos Caetetus (Gália), ele obteve, respectivamente, 27\%, $22 \%, 29 \%$ e $26,7 \%$ do índice de Similaridade de Jaccard, concluindo que a proximidade entre as áreas é o principal determinante na definição da similaridade.

Efetuando-se a análise de similaridade florística entre dois trechos de floresta contínua da Estação Ecológica dos Caetetus, obteve-se para Jaccard o valor de $33 \%$, apesar das diferenças fisiográficas entre as áreas, novamente a proximidade espacial foi determinante na similaridade florística entre trechos florestais. Porém, quando comparamos as espécies amostradas em toda a extensão da E. E. dos Caetetus com os dados obtidos por (Stella et al.) $)^{2}$, no P. E. do Morro do Diabo, utilizando método semelhante de amostragem, obteve-se $50 \%$ de similaridade, apesar da distância de aproximadamente 300 $\mathrm{km}$.

\footnotetext{
2 STELLA, A.; DURIGAN, G; FRANCO, G.A.D.C. Critérios para seleção de espécies arbóreas prioritárias para conservação na Floresta Estacional Semidecidual. (Não publicado).
} 


\begin{tabular}{|c|c|c|}
\hline Familias e espécies & Área A & Área B \\
\hline \multicolumn{3}{|l|}{ Anacardiaceae 2} \\
\hline 1 Astronium graveolens Jacq. & $\mathrm{X}$ & $\mathrm{X}$ \\
\hline 2 Tapirira guianensis Aubl. & $\mathrm{x}$ & \\
\hline \multicolumn{3}{|l|}{ Annonaceae 4} \\
\hline 3 Annona cacans Warm. & $\mathrm{X}$ & \\
\hline 4 Duguetia lanceolata A.St.-Hil. & $\mathrm{X}$ & \\
\hline 5 Rollinia exalbida (Vell.) Mart. & $\mathrm{X}$ & \\
\hline 6 Xylopia brasiliensis (L.) Spreng. & $\mathrm{X}$ & \\
\hline \multicolumn{3}{|l|}{ Apocynaceae 5} \\
\hline 7 Aspidosperna cylindrocarpon Müll.Arg. & & $\mathrm{X}$ \\
\hline \multicolumn{3}{|l|}{8 Aspidosperna parvifolium A.DC. } \\
\hline 9 Aspidosperna polyneuron Müll.Arg. & $\mathrm{x}$ & $\mathrm{x}$ \\
\hline \multicolumn{3}{|l|}{10 Rauvolfia sellowii Müll.Arg. } \\
\hline \multicolumn{3}{|l|}{11 Tabernaemontana hystrix Steud. } \\
\hline \multicolumn{3}{|l|}{ Araliaceae 4} \\
\hline \multicolumn{3}{|l|}{12 Dendropanax cuneatum (DC.) Decne. \& Planch. } \\
\hline 13 Didymopanax calvum (Cham.) Decne. \& Planch. & $x$ & \\
\hline $\begin{array}{l}14 \text { Didymopanax morototoni (Aubl.) Decne. \& } \\
\text { Planch. }\end{array}$ & $x$ & \\
\hline 15 Sciadodendron excelsum Griseb. & & $\mathrm{x}$ \\
\hline \multicolumn{3}{|l|}{ Arecaceae 3} \\
\hline \multicolumn{3}{|l|}{16 Euterpe edulis Mart. } \\
\hline 17 Syagrus oleracea (Mart.) Becc. & & $\mathrm{X}$ \\
\hline 18 Syagrus romanzoffiana (Cham.) Glassm. & $\mathrm{x}$ & $\mathrm{X}$ \\
\hline \multicolumn{3}{|l|}{ Asteraceae 4} \\
\hline \multicolumn{3}{|l|}{19 Gochnatia polymorpha (Less.) Cabrera } \\
\hline 20 Piptocarpha axillaris (Less.) Baker & & $\mathrm{x}$ \\
\hline 21 Piptocarpha sellowii (Sch.Bip.) Baker & $\mathrm{x}$ & $\mathrm{x}$ \\
\hline 22 Vernonia diffusa Less. & & \\
\hline
\end{tabular}

Quadro 1 - Lista das espécies arbustivo-arbóreas da E. E. dos Caetetus com as famílias e respectivos $n^{\circ}$ de espécies assinaladas nas colunas $A$ e $B$ representam as espécies que ocorrem respectivamente nos topos, (área $A$ ) e nos baixios (área $B$ ) e as não assinaladas correspondem às espécies amostradas no levantamento florístico. 


\begin{tabular}{|l|c|c|}
\hline Familias e espécies & Área A & Área B \\
\hline Bignoniaceae 5 & $\mathrm{X}$ & \\
\hline 23 Jacaranda micrantha Cham. & & \\
\hline 24 Tabebuia chrysotricha (Mart. ex DC.) Standl. & & \\
\hline 25 Tabebuia heptaphylla (Vell.) Toledo & & \\
\hline 26 Tabebuia ochracea (Cham.) Standl. & $\mathrm{X}$ & $\mathrm{X}$ \\
\hline 27 Zeyheria tuberculosa (Vell.) Bureau & & \\
\hline Bombacaceae 2 & $\mathrm{X}$ & $\mathrm{X}$ \\
\hline 28 Chorisia speciosa A.St.-Hil. & & \\
\hline 29 Pseudobombax grandiflorum (Cav.) A.Robyns & & \\
\hline Boraginaceae 5 & $\mathrm{X}$ & $\mathrm{X}$ \\
\hline 30 Cordia ecalyculata Vell. & $\mathrm{X}$ & \\
\hline 31 Cordia sellowiana Cham. & & \\
\hline 32 Cordia superba Cham. & & \\
\hline 33 Cordia trichotoma (Vell.) Arrab. ex Steud. & & $\mathrm{X}$ \\
\hline 34 Patagonula americana L. & & \\
\hline Burseraceae 1 & & \\
\hline 35 Protium heptaphyllum (Aubl.) Marchand & & \\
\hline Caesalpiniaceae 9 & & \\
\hline 36 Bauhinia longifolia (Bong.) Steud. & $\mathrm{X}$ & $\mathrm{X}$ \\
\hline 37 Cassia ferruginea Schrad. ex DC. & $\mathrm{X}$ & \\
\hline 38 Copaifera langsdorffii Desf. & $\mathrm{X}$ & \\
\hline 39 Holocalyx balansae Micheli & & $\mathrm{X}$ \\
\hline 40 Hymaneae courbaril L. & & \\
\hline 41 Peltophorum dubium (Spreng.) Taub. & \\
\hline 42 Pterogyne nitens Tul. & & \\
\hline 43 Senna biflora L. & & \\
\hline 44 Senna pendula (Willd.) H. S. Irwin \& Barneby & & \\
\hline Caricaceae 1 & & \\
\hline 45 Jacaratia spinosa A.DC. & & \\
\hline Cecropiaceae 2 & & \\
\hline
\end{tabular}

Quadro 1 - Lista das espécies arbustivo-arbóreas da E. E. dos Caetetus com as famílias e respectivos $n^{\circ}$ de espécies assinaladas nas colunas $A$ e $B$ representam as espécies que ocorrem respectivamente nos topos, (área $A$ ) e nos baixios (área $B$ ) e as não assinaladas correspondem às espécies amostradas no levantamento florístico. 


\begin{tabular}{|l|c|c|}
\hline Familias e espécies & Área A & Área B \\
\hline 46 Cecropia glaziouii Snethl. & & \\
\hline 47 Cecropia pachystachya Trécul & & \\
\hline Celastraceae 3 & & \\
\hline 48 Maytenus aquifolium Mart. & & \\
\hline 49 Maytenus robusta Reiss. & & \\
\hline 50 Maytenus sp. & & \\
\hline Chloranthaceae 1 & & \\
\hline 51 Hedyosmum brasiliense Mart. ex Miq. & & \\
\hline Clusiaceae 1 & & \\
\hline 52 Calophyllum brasiliensis Cambess. & & \\
\hline Combretaceae 1 & & \\
\hline 53 Terminalia brasiliensis (Cambess.) Eichler & $\mathrm{X}$ & $\mathrm{X}$ \\
\hline Elaeocarpaceae 1 & & \\
\hline 54 Sloanea monosperma Vell. & & \\
\hline Erythoxylaceae 1 & & \\
\hline 55 Erythroxylum deciduum A.St.-Hil. & $\mathrm{X}$ & $\mathrm{X}$ \\
\hline Euphorbiaceae 17 & $\mathrm{X}$ & $\mathrm{X}$ \\
\hline 56 Actinostemon concepcionis (Chodat \& Hassl.) & $\mathrm{X}$ & $\mathrm{X}$ \\
\hline Pa \& K.Hoffm. & $\mathrm{X}$ & \\
\hline 57 Actinostemon concolor (Spreng.) Müll.Arg. & $\mathrm{X}$ & \\
\hline 58 Alchornea glandulosa Poepp. & $\mathrm{X}$ & $\mathrm{X}$ \\
\hline 59 Alchornea triplinervia (Spreng.) Müll.Arg. & & \\
\hline 60 Aparistimum cordatum (A.Juss.) Baill. & $\mathrm{X}$ & \\
\hline 61 Croton floribundus (L.) Spreng. & $\mathrm{X}$ & \\
\hline 62 Croton urucurana Baill. & $\mathrm{X}$ & \\
\hline 63 Hyeronima alchorneoides Allemão & & \\
\hline 64 Mabea fistulifera Mart. & & \\
\hline 65 Maprounea guianensis Aubl. & & \\
\hline 66 Margaritalia nobilis L.f. & & \\
\hline 67 Micrandra elata (Didr.) Mull.Arg. & & \\
\hline
\end{tabular}

Quadro 1 - Lista das espécies arbustivo-arbóreas da E. E. dos Caetetus com as familias e respectivos $n^{\circ}$ de espécies assinaladas nas colunas $A$ e $B$ representam as espécies que ocorrem respectivamente nos topos, (área $A$ ) e nos baixios (área B) e as não assinaladas correspondem às espécies amostradas no levantamento florístico. 


\begin{tabular}{|l|c|c|}
\hline Famílias e espécies & Área A & Área B \\
\hline 68 Pachystroma longifolium (Nees) I.M. Johnston & & \\
\hline 69 Pera glabrata (Schott) Baill. & $\mathrm{X}$ & \\
\hline 70 Sapium glandulatum (Vell.) Pax & & \\
\hline 71 Savia dyctiocarpa M. Arg. & $\mathrm{X}$ & $\mathrm{X}$ \\
\hline 72 Sebastiania commersoniana (Baill.) Müll.Arg. & & \\
\hline Fabaceae 12 & $\mathrm{X}$ & $\mathrm{X}$ \\
\hline 73 Centrolobium tomentosum Guill. ex Benth. & & \\
\hline 74 Dalbergia frutescens (Vell.) Britton & $\mathrm{X}$ & $\mathrm{X}$ \\
\hline 75 Lonchocarpus cultratus (Tul.) Malme & $\mathrm{X}$ & $\mathrm{X}$ \\
\hline 76 Machaerium brasiliense Vogel & & \\
\hline 77 Machaerium hirtum Raddi & & $\mathrm{X}$ \\
\hline 78 Machaerium nyctitans (Vell.) Benth. & $\mathrm{X}$ & $\mathrm{X}$ \\
\hline 79 Machaerium stipitatum Vogel & & $\mathrm{X}$ \\
\hline 80 Myroxylon peruiferum L.f. & $\mathrm{X}$ & \\
\hline 81 Ormosia arborea (Vell.) Harms & $\mathrm{X}$ & \\
\hline 82 Platyciamus regnellii Benth. & & \\
\hline 83 Platypodium elegans Vogel & $\mathrm{X}$ & \\
\hline 84 Sweetia fruticosa (L.) Spreng. & & \\
\hline Flacourtiaceae 5 & $\mathrm{X}$ & $\mathrm{X}$ \\
\hline 85 Casearia gossypiosperma Briq. & $\mathrm{X}$ & \\
\hline 86 Casearia obliqua Spreng. & $\mathrm{X}$ & \\
\hline 87 Casearia sylvestris Sw. & & \\
\hline 88 Prockia crucis P. Browne ex L. & & \\
\hline 89 Xylosma pseudosalzmanii Sleumer & & \\
\hline Icacinaceae 2 & & \\
\hline 90 Citronella gongonha (Miers) Howard & & \\
\hline 91 Citronella paniculata (Mart.) Howard & & \\
\hline Lacistemataceae 1 & & \\
\hline 92 Lacistema hasslerianum Chodat. & & \\
\hline
\end{tabular}

Quadro 1- Lista das espécies arbustivo-arbóreas da E. E. dos Caetetus com as famílias e respectivos $n^{\circ}$ de espécies assinaladas nas colunas $A$ e $B$ representam as espécies que ocorrem respectivamente nos topos, (área $A$ ) e nos baixios (área B) e as não assinaladas correspondem às espécies amostradas no levantamento florístico. 


\begin{tabular}{|l|c|c|}
\hline Famílias e espécies & Área A & Área B \\
\hline Lauraceae 12 & & \\
\hline 93 Endlicheria paniculata (Spreng.) J.F.Macbr. & & \\
\hline 94 Nectandra cuspidata Nees & & \\
\hline 95 Nectandra lanceolata Nees & $\mathrm{X}$ & $\mathrm{X}$ \\
\hline 96 Nectandra megapotamica (Spreng.) Mez & $\mathrm{X}$ & \\
\hline 97 Nectandra oppositifolia Nees & $\mathrm{X}$ & \\
\hline 98 Ocotea corymbosa (Meisn.) Mez & $\mathrm{X}$ & \\
\hline 99 Ocotea dyospirifolia (Meisn.) Mez & $\mathrm{X}$ & $\mathrm{X}$ \\
\hline 100 Ocotea indecora Schott ex Meisn. & & \\
\hline 101 Ocotea silvestris Vattimo-Gil & & \\
\hline 102 Ocotea vellozziana (Meisn.) Mez & & \\
\hline 103 Ocotea velutina (Nees) Rohwer & & \\
\hline 104 Persea pyrifolia Nees ex Mart. ex Nees & & \\
\hline Lecythidaceae 1 & $\mathrm{X}$ & $\mathrm{X}$ \\
\hline 105 Cariniana estrellensis (Raddi) O.Kuntze & & \\
\hline Magnoliaceae 1 & & \\
\hline 106 Talauma ovata A.St.-Hil. & & \\
\hline Malpighiaceae 1 & & $\mathrm{X}$ \\
\hline 107 Bunchosia pallescens Scottsb. & & \\
\hline Malvaceae 1 & & \\
\hline 108 Bastardiopsis densiflora (Hook. \& Arn.) Hassl. & & \\
\hline Melastomataceae 7 & & \\
\hline 109 Leandra sp. & & \\
\hline 110 Miconia calvescens DC. & & \\
\hline 111 Miconia discolor DC. & & \\
\hline 112 Miconia hymenonervia Cogn. & & \\
\hline 113 Miconia latecrenata (DC.) Naud. & & \\
\hline 114 Miconia sp. 1 & & \\
\hline 115 Miconia sp. 2 & & \\
\hline
\end{tabular}

Quadro 1 - Lista das espécies arbustivo-arbóreas da E. E. dos Caetetus com as famílias e respectivos $n^{\circ}$ de espécies assinaladas nas colunas $A$ e $B$ representam as espécies que ocorrem respectivamente nos topos, (área $A$ ) e nos baixios (área B) e as não assinaladas correspondem às espécies amostradas no levantamento florístico. 


\begin{tabular}{|l|c|c|}
\hline Famílias e espécies & Área A & Área B \\
\hline Meliaceae 9 & & \\
\hline 116 Cabralea canjerana (Vell.) Mart. & $\mathrm{X}$ & $\mathrm{X}$ \\
\hline 117 Cedrela fissilis Vell. & & $\mathrm{X}$ \\
\hline 118 Guarea guidonia (L.) Sleumer & & $\mathrm{X}$ \\
\hline 119 Guarea kunthiana A.Juss. & $\mathrm{X}$ & \\
\hline 120 Trichilia casaretti C.DC. & $\mathrm{X}$ & $\mathrm{X}$ \\
\hline 121 Trichilia catigua A.Juss. & & $\mathrm{X}$ \\
\hline 122 Trichilia claussenii C.DC. & & \\
\hline 123 Trichilia elegans A.Juss. & $\mathrm{X}$ & $\mathrm{X}$ \\
\hline 124 Trichilia pallida Sw. & & \\
\hline Mimosaceae 9 & & $\mathrm{X}$ \\
\hline 125 Acacia polyphylla DC. & $\mathrm{X}$ & \\
\hline 126 Albizia hasslerii (Chodat) Burkart & & $\mathrm{X}$ \\
\hline 127 Albizia polycephala (Benth.) Killip & $\mathrm{X}$ & $\mathrm{X}$ \\
\hline 128 Calliandra foliolosa Benth. & & $\mathrm{X}$ \\
\hline 129 Enterolobium contortisiliquum (Vell.) Morong & & $\mathrm{X}$ \\
\hline 130 Inga marginata Willd. & $\mathrm{X}$ & $\mathrm{X}$ \\
\hline 131 Inga striata Benth. & & $\mathrm{X}$ \\
\hline 132 Parapiptadenia rigida (Benth.) Brenan & $\mathrm{X}$ & $\mathrm{X}$ \\
\hline 133 Piptadenia gonoacantha (Mart.) J.F.Macbr. & & \\
\hline Monimiaceae 2 & $\mathrm{X}$ & $\mathrm{X}$ \\
\hline 134 Mollinedia widgrenii A.DC. & & \\
\hline 135 Siparuna guianensis Aubl. & & \\
\hline Moraceae 8 & & \\
\hline 136 Ficus enormis (Mart. ex Miq.) Miq. & & \\
\hline 137 Ficus guaranitica Chodat & & \\
\hline 138 Ficus insipida Willd. & & \\
\hline 139 Ficus obtusifolia H.B.K. & & \\
\hline 140 Ficus sp. 1 & & \\
\hline
\end{tabular}

Quadro 1 - Lista das espécies arbustivo-arbóreas da E. E. dos Caetetus com as famílias e respectivos $n^{\circ}$ de espécies assinaladas nas colunas $A$ e $B$ representam as espécies que ocorrem respectivamente nos topos, (área $A$ ) e nos baixios (área B) e as não assinaladas correspondem às espécies amostradas no levantamento florístico. 


\begin{tabular}{|l|c|c|}
\hline Familias e espécies & Área A & Área B \\
\hline 141 Ficus sp. 2 & $\mathrm{X}$ & \\
\hline 142 Maclura tinctoria (L.) D.Don ex Steud. & & \\
\hline 143 Sorocea bonplandii (Baill.) Burger, Lanj. \& Boer & & $\mathrm{X}$ \\
\hline Myrsinaceae 4 & & \\
\hline 144 Ardisia sp. & & \\
\hline 145 Rapanea ferruginea (Ruiz \& Pav.) Mez & & \\
\hline 146 Rapanea sp. & $\mathrm{X}$ & \\
\hline 147 Rapanea umbellata (Mart.) Mez & & \\
\hline Myrtaceae 22 & & \\
\hline 148 Blepharocalyx salicifolius (H.B.K.) O.Berg & $\mathrm{X}$ & \\
\hline 149 Calypthranthes clusiaefolia (Miq.) O. Berg & & \\
\hline 150 Calypthranthes concinna DC. & & \\
\hline 151 Calypthranthes sp. 1 & & \\
\hline 152 Campomanesia guazumifolia (Cambess.) & \\
\hline O.Berg & & $\mathrm{X}$ \\
\hline 153 Campomanesia rhombea O.Berg & & $\mathrm{X}$ \\
\hline 154 Campomanesia xanthocarpa O.Berg & $\mathrm{X}$ & $\mathrm{X}$ \\
\hline 155 Eugenia blastantha (O.Berg) D.Legrand & $\mathrm{X}$ & $\mathrm{X}$ \\
\hline 156 Eugenia florida DC. & & \\
\hline 157 Eugenia moraviana O.Berg & & \\
\hline 158 Eugenia ramboi D.Legrand & $\mathrm{X}$ & \\
\hline 159 Eugenia sp. 1 & & \\
\hline 160 Eugenia sp. 2 & & \\
\hline 161 Myrcia bella Cambess. & & \\
\hline 162 Myrcia fallax (Rich.) DC. & & \\
\hline 163 Myrcianthes pungens (O.Berg) D.Legrand & & \\
\hline 164 Myrciaria ciliolata O.Berg & & \\
\hline 165 Myrciaria sp. 1 & & \\
\hline 166 Myrciaria sp. 2 & & \\
\hline
\end{tabular}

Quadro 1 - Lista das espécies arbustivo-arbóreas da E. E. dos Caetetus com as famílias e respectivos $n^{\circ}$ de espécies assinaladas nas colunas $A$ e $B$ representam as espécies que ocorrem respectivamente nos topos, (área $A$ ) e nos baixios (área $B$ ) e as não assinaladas correspondem às espécies amostradas no levantamento florístico. 


\begin{tabular}{|l|c|c|}
\hline Familias e espécies & Área A & Área B \\
\hline $\begin{array}{l}167 \text { Neomithranthes glomerata (D.Legrand) } \\
\text { D.Legrand }\end{array}$ & $\mathrm{X}$ & $\mathrm{X}$ \\
\hline 168 Plinia rivularis (Cambess.) Rotman & & \\
\hline 169 Syzygium cumini (L.) Skeels & & \\
\hline Nyctaginaceae 4 & & \\
\hline 170 Bouganvillea glabra Choisy & & \\
\hline 171 Guapira hirsuta (Choisy) Lundell & & \\
\hline 172 Guapira opposita (Vell.) Reitz & $\mathrm{X}$ & $\mathrm{X}$ \\
\hline 173 Pisonia ambigua Heimerl & & \\
\hline Opiliaceae 1 & $\mathrm{X}$ & $\mathrm{X}$ \\
\hline 174 Agonandra englerii Hoehne & & \\
\hline Phytolaccaceae 3 & & $\mathrm{X}$ \\
\hline 175 Gallesia integrifolia (Spreng.) Harms & & \\
\hline 176 Phytolacca dioica L. & & \\
\hline 177 Seguieria floribunda Benth. & & \\
\hline Piperaceae 1 & & $\mathrm{X}$ \\
\hline 178 Piper arboreum Aubl. & & \\
\hline Polygonaceae 1 & & \\
\hline 179 Ruprechtia sp. & & \\
\hline Proteaceae 1 & $\mathrm{X}$ & \\
\hline 180 Roupala brasiliensis Klotzsch & $\mathrm{X}$ & \\
\hline Rhamnaceae 2 & $\mathrm{X}$ & $\mathrm{X}$ \\
\hline 181 Colubrina glandulosa Perkins & \\
\hline 182 Rhamnidium elaeocarpum Reissek & \\
\hline Rosaceae 1 & & \\
\hline 183 Prunus myrtifolia (L.) Urb. & \\
\hline Rubiaceae 6 & & \\
\hline 184 Amaioua intermedia Mart. & & \\
\hline 185 Chomelia pohliana Muell. Arg. & & \\
\hline 186 Coutarea hexandra (Jacq.) K.Schum. & & \\
\hline
\end{tabular}

Quadro 1 - Lista das espécies arbustivo-arbóreas da E. E. dos Caetetus com as famílias e respectivos $n^{\circ}$ de espécies assinaladas nas colunas $A$ e $B$ representam as espécies que ocorrem respectivamente nos topos, (área $A$ ) e nos baixios (área B) e as não assinaladas correspondem às espécies amostradas no levantamento florístico. 


\begin{tabular}{|c|c|c|}
\hline Famílias e espécies & Área $\mathrm{A}$ & Área B \\
\hline 187 Ixora venulosa Benth. & & $\mathrm{x}$ \\
\hline \multicolumn{3}{|l|}{188 Randia armata (Sw.) DC. } \\
\hline \multicolumn{3}{|l|}{189 Rudgea jasminoides (Cham.) Müll.Arg. } \\
\hline \multicolumn{3}{|l|}{ Rutaceae 16} \\
\hline 190 Balfourodendron riedelianum (Engl.) Engl. & $x$ & $\mathrm{X}$ \\
\hline \multicolumn{3}{|l|}{$\begin{array}{l}191 \text { Esenbeckia febrifuga (A.St.-Hil.) A.Juss. ex } \\
\text { Mart. }\end{array}$} \\
\hline 192 Esenbeckia grandiflora Mart. & $x$ & \\
\hline 193 Esenbeckia leiocarpa Engl. & $\mathrm{X}$ & \\
\hline \multicolumn{3}{|l|}{194 Helietta apiculata Benth. } \\
\hline 195 Metrodorea nigra A.St.-Hil. & & $\mathrm{X}$ \\
\hline 196 Pilocarpus pauciflorus A.St.-Hil. & $\mathrm{x}$ & $\mathrm{X}$ \\
\hline 197 Pilocarpus pennatifolius Lem. & & $\mathrm{x}$ \\
\hline \multicolumn{3}{|l|}{198 Zanthoxylum caribaeum Lam. } \\
\hline 199 Zanthoxylum fagara (L.)Sarg. & & $\mathrm{x}$ \\
\hline \multicolumn{3}{|l|}{200 Zanthoxylum petiolare A.St.-Hil. \& Tul. } \\
\hline 201 Zanthoxylum pohlianum Engl. & $\mathrm{X}$ & \\
\hline \multicolumn{3}{|l|}{202 Zanthoxylum rhoifolium Lam. } \\
\hline 203 Zanthoxylum juniperinum Poeppig & $\mathrm{X}$ & $\mathrm{X}$ \\
\hline \multicolumn{3}{|l|}{204 Zanthoxylum rugosum A.St.-Hil. \& Tul. } \\
\hline \multicolumn{3}{|l|}{205 Zanthoxylum sp. 1} \\
\hline \multicolumn{3}{|l|}{ Sapindaceae 5} \\
\hline \multicolumn{3}{|l|}{206 Allophylus edulis (A.St.-Hil.) Radlk. } \\
\hline \multicolumn{3}{|l|}{207 Cupania vernalis Cambess. } \\
\hline 208 Cupania zanthoxyloides Cambess. & $\mathrm{X}$ & $x$ \\
\hline 209 Diatenopteryx sorbifolia Radlk. & & $\mathrm{X}$ \\
\hline \multicolumn{3}{|l|}{210 Matayba elaeagnoides Radlk. } \\
\hline \multicolumn{3}{|l|}{ Sapotaceae 3} \\
\hline $\begin{array}{l}211 \text { Chrysophyllum gonocarpum (Mart. \& Eichler) } \\
\text { Engl. }\end{array}$ & $\mathrm{X}$ & $x$ \\
\hline
\end{tabular}

Quadro 1 - Lista das espécies arbustivo-arbóreas da E. E. dos Caetetus com as famílias e respectivos $n^{\circ}$ de espécies assinaladas nas colunas $A$ e $B$ representam as espécies que ocorrem respectivamente nos topos, (área A) e nos baixios (área $B$ ) e as não assinaladas correspondem às espécies amostradas no levantamento floristico. 


\begin{tabular}{|l|c|c|}
\hline Familias e espécies & Área A & Área B \\
\hline 212 Chrysophyllum marginatum (Hook. \& Arn.) & & \\
Radlk. & $\mathrm{X}$ & \\
\hline 213 Pouteria ramiflora (Mart.) Radlk. & & \\
\hline Simaroubaceae 1 & & $\mathrm{X}$ \\
\hline 214 Picramnia warmigiana Engl. & & \\
\hline Solanaceae 4 & & $\mathrm{X}$ \\
\hline 215 Cestrum calycinum Willd. & & \\
\hline 216 Solanum argenteum Dunal & & $\mathrm{X}$ \\
\hline 217 Solanum mauritianum Scop. & & \\
\hline 218 Solanum pseudoquina A. St. Hill. & & \\
\hline Sterculiaceae 1 & & \\
\hline 219 Guazuma ulmifolia Lam. & & \\
\hline Styracaceae 3 & & \\
\hline 220 Styrax acuminatus Pohl & & \\
\hline 221 Styrax camporum Pohl & & \\
\hline 222 Styrax pohlli A. DC. & & \\
\hline Symplocaceae 2 & & \\
\hline 223 Symplocos sp. 1 & & \\
\hline 224 Symplocos sp. 2 & & \\
\hline Tiliaceae 4 & & \\
\hline 225 Cristiania macrodon Toledo & & \\
\hline 226 Heliocarpus americanus L. & & \\
\hline 227 Luehea candicans Mart. & & \\
\hline 228 Luehea divaricata Mart. & & \\
\hline Ulmaceae 1 & & \\
\hline 229 Trema micrantha (L.) Blume & & \\
\hline Urticaceae 1 & & \\
\hline 230 Urera baccifera (L.) Gaudich. & & \\
\hline Verbenaceae 4 & & \\
\hline 231 Aegiphila sellowiana Cham. & & \\
\hline
\end{tabular}

Quadro 1 - Lista das espécies arbustivo-arbóreas da E. E. dos Caetetus com as famílias e respectivos $n^{\circ}$ de espécies assinaladas nas colunas $A$ e $B$ representam as espécies que ocorrem respectivamente nos topos, (área $A$ ) e nos baixios (área B) e as não assinaladas correspondem às espécies amostradas no levantamento florístico. 


\begin{tabular}{|l|l|l|}
\hline Famílias e espécies & Área A & Área B \\
\hline 232 Aloysia virgata (Ruiz \& Pavon) Juss. & & \\
\hline 233 Cytharexylum myrianthum Cham. & & \\
\hline 234 Vitex montevidensis Cham. & & \\
\hline
\end{tabular}

Quadro 1 - Lista das espécies arbustivo-arbóreas da E. E. dos Caetetus com as famílias e respectivos $n^{\circ}$ de espécies assinaladas nas colunas $A$ e $B$ representam as espécies que ocorrem respectivamente nos topos, (área $A$ ) e nos baixios (área B) e as não assinaladas correspondem às espécies amostradas no levantamento florístico.

Desta forma, é possivel que os remanescentes florestais do estado de São Paulo apresentem similaridade maior que a obtida até então, corroborando a opinião de (Durigan \& Leitão Filho, 1995), que constataram que, quanto maior o número de espécies amostradas (somando-se as espécies da florística e as de fitossociologia), maior a similaridade entre as áreas.

Os levantamentos fitossociológicos são normalmente utilizados para amostrar a diversidade alfa (diversidade de um ambiente). Quando dados de fitossociologia são utilizados para análise de similaridade florística entre áreas distantes, tende-se a subestimar a similaridade, sendo aconselhável a utilização de métodos de amostragem ampla que contemplem os vários ambientes do mosaico, ou seja, que amostrem a diversidade beta. Outro fato a ser considerado sobre a grande similaridade entre a Estação Ecológica dos Caetetus e o Parque Estadual do Morro do Diabo é o de que ambas as áreas são unidades de conservação do governo do estado de São Paulo, sendo protegidas há vários anos, ao passo que as outras áreas alvo de estudo geralmente são fragmentos menores em áreas particulares mais sujeitos à degradação de vários tipos como fogo, efeito de borda e exploração seletiva de madeira. 


\subsection{Chave dicotômica baseada em caracteres vegetativos}

$\mathrm{Na}$ elaboração desta chave, o primeiro critério para que uma determinada espécie fosse incluída é o porte arbustivo-arbóreo. Durante as coletas, freqüentemente esta dúvida surgia ao depararmos com alguma espécie desconhecida. É provável que algumas espécies não tenham sido incluídas nesta chave devido ao desconhecimento de seu hábito. Foi o caso de Piper arboreum, que, apesar de ter sido incluído em uma das análises fitossociológicas, não foi incluído na chave por seu hábito freqüentemente entoucerado e aspecto herbáceo.

Foram incluídas na chave duas espécies exóticas, pois estas encontram-se em regeneração natural no interior da floresta, podendo gerar erros de identificação durante o processo de utilização da chave caso não fossem incluídas.

Iniciamos a construção da chave dicotômica pelas espécies de folhas compostas; este grupo possui uma grande quantidade de caracteres vegetativos distintivos, que facilitou em grande parte a separação das espécies. À medida que iamos avançando na chave, trabalhando com as espécies de folhas simples, notamos que íamos esgotando os caracteres nítidos para distinção dos grupos e no final da chave tínhamos uma mescla de várias famílias de difícil distinção entre suas espécies, tais como: Lauraceae, Solanaceae, Opiliaceae, Euphorbiaceae, Apocinaceae e Boraginaceae. Além disso, muitos grupos de fácil reconhecimento a princípio, tais como Rubiaceae, Melastomataceae e Myrtaceae, foram de difícil separação entre suas espécies (Quadro 2). 


\begin{tabular}{|c|c|c|c|c|}
\hline 1 & a. & Folhas compostas & & 2 \\
\hline & b. & Folhas simples & & 82 \\
\hline 2 & a. & $\begin{array}{l}\text { Palmeiras (nervuras paralelas } \\
\text { - Monocotiledôneas) }\end{array}$ & & 3 \\
\hline & b. & $\begin{array}{l}\text { Nervuras reticuladas - } \\
\text { (Dicotiledôneas) }\end{array}$ & & 5 \\
\hline 3 & a. & $\begin{array}{l}\text { Folíolos eqüidistantes e } \\
\text { dísticos }\end{array}$ & Euterpe edulis & \\
\hline & b. & $\begin{array}{l}\text { Folíolos em feixes e em vários } \\
\text { planos }\end{array}$ & & 4 \\
\hline 4 & a. & Folíolos flexuosos & Syagrus rommanzoffiana & \\
\hline & b. & Folíolos não flexuosos & Syagrus oleracea & \\
\hline 5 & a. & $\begin{array}{l}\text { Folhas digitadas ou } \\
\text { digitipinadas }\end{array}$ & & 6 \\
\hline & b. & $\begin{array}{l}\text { Outro tipo (bifoliolada, } \\
\text { ternadas, pinadas, bipinadas) }\end{array}$ & & 16 \\
\hline 6 & a. & Folhas digitipinadas & Sciadodendron excelsum & \\
\hline & b. & Folhas digitadas & & 7 \\
\hline 7 & a. & Folhas opostas & & 8 \\
\hline & b. & Folhas alternas & & 12 \\
\hline 8 & a. & $\begin{array}{l}\text { Folhas discolores, nervuras } \\
\text { impressas na face superior do } \\
\text { limbo, planta densamente } \\
\text { pilosa }\end{array}$ & Zeyhera tuberculosa & \\
\hline & b. & $\begin{array}{l}\text { Folhas concolores, glabras a } \\
\text { pouco pilosas }\end{array}$ & & 9 \\
\hline 9 & a. & $\begin{array}{l}\text { Folólos de folhas adultas de } \\
\text { bordo liso, base aguda a } \\
\text { atenuada }\end{array}$ & Vitex montevidensis & \\
\hline & b. & Folíolos de bordo serreado & & 10 \\
\hline 10 & a. & $\begin{array}{l}\text { Folíolos oval-lanceolados, } \\
\text { bordo serreado da base ao } \\
\text { ápice, base arredondada, } \\
\text { planta totalmente glabra }\end{array}$ & Tabebuia heptaphylla & \\
\hline & b. & $\begin{array}{l}\text { Folíolos lanceolados a } \\
\text { obovados, bordo serreado nos } \\
2 / 3 \text { posteriores do limbo, base } \\
\text { aguda a truncada, folhas } \\
\text { pilosas }\end{array}$ & & 11 \\
\hline
\end{tabular}

Quadro 2 - Chave dicotômica para as espécies arbustivo-arbóreas da E. E. dos Caetetus. 


\begin{tabular}{|c|c|c|c|c|}
\hline 11 & a. & $\begin{array}{l}\text { Pêlos esbranquiçados nos } \\
\text { ramos jovens e na face } \\
\text { inferior do limbo }\end{array}$ & Tabebuia ochracea & \\
\hline & b. & $\begin{array}{l}\text { Pêlos ferrugíneos nos ramos } \\
\text { jovens e na face inferior do } \\
\text { limbo }\end{array}$ & Tabebuia chrysotricha & \\
\hline 12 & a. & $\begin{array}{l}\text { Folíolos discolores, pilosidade } \\
\text { ocrácea na face inferior }\end{array}$ & Didymopanax morototoni & \\
\hline & b. & Foliolos concolores & & 13 \\
\hline 13 & a. & Planta armada & & 14 \\
\hline & b. & Planta inerme & . & 15 \\
\hline 14 & a. & $\begin{array}{l}\text { Folíolos com bordo serreado, } \\
\text { geralmente em número de } 5\end{array}$ & Chorisia speciosa & \\
\hline & b. & $\begin{array}{l}\text { Folíolos com bordo liso, em } \\
\text { número maior que } 7\end{array}$ & Jacaratia spinosa & \\
\hline 15 & a. & Folíolos sub-sésseis glabros & $\begin{array}{l}\text { Pseudobombax } \\
\text { grandiflorum }\end{array}$ & \\
\hline & b. & $\begin{array}{l}\text { Folíolos longi-peciolados, } \\
\text { pecíolo amplexicaule }\end{array}$ & Didymopanax calvum & \\
\hline 16 & a. & Folhas com até 3 folíolos & & 17 \\
\hline & b. & Folhas com mais de 3 foliolos & & 25 \\
\hline 17 & a. & Folhas com 2 folíolos & & 18 \\
\hline & b. & Folhas com 3 folíolos & & 19 \\
\hline 18 & a. & Folíolos fundidos & Bauhinia longifolia & \\
\hline & b. & Folíolos livres & Hymenaea courbaril & \\
\hline 19 & a. & Folhas opostas & & 20 \\
\hline & b. & Folhas alternas & & 23 \\
\hline 20 & a. & $\begin{array}{l}\text { Pecíolo amplexicaule com } \\
\text { esporão }\end{array}$ & Metrodorea nigra & \\
\hline & b. & \begin{tabular}{|l} 
Pecíolo sem esta \\
característica
\end{tabular} & & 21 \\
\hline 21 & a. & $\begin{array}{l}\text { Presença de domácias na } \\
\text { base das nervuras } \\
\text { secundárias }\end{array}$ & $\begin{array}{l}\text { Balfourodendron } \\
\text { riedelianum }\end{array}$ & \\
\hline & b. & Ausência de domácias & & 22 \\
\hline 22 & a. & $\begin{array}{l}\text { Folíolos sésseis, estreitos, } \\
\text { lanceolados, ápice apiculado }\end{array}$ & Helietta longifoliolata & \\
\hline
\end{tabular}

Quadro 2 - Chave dicotômica para as espécies arbustivo-arbóreas da E. E. dos Caetetus. 


\begin{tabular}{|c|c|c|c|c|}
\hline & b. & $\begin{array}{l}\text { Folíolos peciolados, } \\
\text { lanceolados a oval- } \\
\text { lanceolados, ápice de obtuso } \\
\text { a agudo-rostrato }\end{array}$ & Esenbeckia febrifuga & \\
\hline \multirow[t]{2}{*}{23} & a. & Margem serreada & Alophyllus edulis & \\
\hline & b. & Margem lisa & & 25 \\
\hline \multirow{2}{*}{24} & a. & Folhas com estipulas & Platcyamus regneli & \\
\hline & b. & Folhas sem estipulas & Trichilia clausseni & \\
\hline \multirow[t]{2}{*}{25} & a. & Folhas pinadas & & 26 \\
\hline & b. & Folhas bipinadas & & 74 \\
\hline \multirow[t]{2}{*}{26} & a. & $\begin{array}{l}\text { Folhas terminando em } \\
\text { apêndices ou gemas de } \\
\text { crescimento }\end{array}$ & & 27 \\
\hline & b. & Folhas pari ou imparipinadas & & 32 \\
\hline \multirow[t]{2}{*}{27} & a. & $\begin{array}{l}\text { Ráquis terminando em } \\
\text { apêndices }\end{array}$ & & 28 \\
\hline & b. & $\begin{array}{l}\text { Ráquis terminando em gemas } \\
\text { de crescimento }\end{array}$ & & 31 \\
\hline \multirow[t]{2}{*}{28} & a. & Bordo liso & & 29 \\
\hline & b. & Bordo serreado & & 30 \\
\hline \multirow[t]{2}{*}{29} & a. & $\begin{array}{l}\text { Ápice arredondado, face } \\
\text { superior brilhante, folíolos } \\
\text { menores que } 5 \mathrm{~cm} \text { de } \\
\text { comprimento }\end{array}$ & Pterogyne nitens & \\
\hline & b. & $\begin{array}{l}\text { Ápice agudo, face superior } \\
\text { opaca, folíolos maiores que } 5 \\
\text { cm de comprimento }\end{array}$ & Matayba eleagnoides & \\
\hline \multirow[t]{2}{*}{30} & a. & $\begin{array}{l}\text { Folíolos de } 2 \text { a } 5 \mathrm{~cm} \text { de } \\
\text { comprimento }\end{array}$ & Cupania zanthoxylloides & \\
\hline & b. & $\begin{array}{l}\text { Folíolos de } 5 \text { a } 12 \mathrm{~cm} \text { de } \\
\text { comprimento }\end{array}$ & Cupania vernalis & \\
\hline \multirow[t]{2}{*}{31} & a. & $\begin{array}{l}\text { Face superior sub-lustrosa, } \\
\text { nervação terciária nítida, } \\
\text { folíolos elipitco-lanceolados a } \\
\text { oblongos }\end{array}$ & Guarea guidonea & \\
\hline & b. & $\begin{array}{l}\text { Face superior opaca a sub- } \\
\text { opaca, nervação terciária } \\
\text { inconspícua, folíolos elípticos }\end{array}$ & Guarea kunthiana & \\
\hline 32 & a. & $\begin{array}{l}\text { Folhas paripinadas (sem } \\
\text { folíolo terminal) }\end{array}$ & & 33 \\
\hline
\end{tabular}

Quadro 2 - Chave dicotômica para as espécies arbustivo-arbóreas da E. E. dos Caetetus. 


\begin{tabular}{|c|c|c|c|c|}
\hline & b. & $\begin{array}{l}\text { Folhas imparipinadas (com } \\
\text { foliolo terminal ou sub- } \\
\text { terminal) }\end{array}$ & & 44 \\
\hline \multirow[t]{2}{*}{33} & a. & $\begin{array}{l}\text { Presença de glândulas } \\
\text { translúcidas nos folíolos }\end{array}$ & & 34 \\
\hline & b. & $\begin{array}{l}\text { Glândulas translúcidas } \\
\text { ausentes ou outro tipo que } \\
\text { não translúcida }\end{array}$ & & 37 \\
\hline \multirow[t]{2}{*}{34} & a. & $\begin{array}{l}\text { Glândulas translúcidas em } \\
\text { todo o limbo }\end{array}$ & & 35 \\
\hline & b. & $\begin{array}{l}\text { Glândulas translúcidas } \\
\text { somente no bordo dos folíolos }\end{array}$ & & 36 \\
\hline \multirow[t]{2}{*}{35} & a. & $\begin{array}{l}\text { Folilos elípticos, base e ápice } \\
\text { arredondados }\end{array}$ & Copaifera langsdorffii & \\
\hline & b. & $\begin{array}{l}\text { Folílos lanceolados, base e } \\
\text { ápice agudos }\end{array}$ & Zanthoxyllum sp 1 & \\
\hline \multirow[t]{2}{*}{36} & a. & $\begin{array}{l}\text { Folíolos discolores, cartáceos } \\
\text { a coriáceos }\end{array}$ & $\begin{array}{l}\text { Zanthoxyllum } \\
\text { juniperinum }\end{array}$ & \\
\hline & b. & $\begin{array}{l}\text { Folíolos concolores, } \\
\text { membranáceos }\end{array}$ & Zanthoxyllum petiolare & \\
\hline \multirow[t]{2}{*}{37} & a. & $\begin{array}{l}\text { Ráqui alada, glândulas } \\
\text { (nectários) interpeciolares em } \\
\text { todos os pares de folíolos } \\
\text { (jugas) }\end{array}$ & & 38 \\
\hline & b. & $\begin{array}{l}\text { Ráqui não alada, sem } \\
\text { glândulas ou com glândulas } \\
\text { apenas entre o primeiro par } \\
\text { de folíolos }\end{array}$ & & 39 \\
\hline 38 & a. & $\begin{array}{l}\text { Folhas glabras, dois a três } \\
\text { pares de foliolos }\end{array}$ & Inga marginata & \\
\hline . & b. & $\begin{array}{l}\text { Folhas pilosas, quatro pares } \\
\text { de folíolos }\end{array}$ & Inga striata & \\
\hline \multirow[t]{2}{*}{39} & a. & $\begin{array}{l}\text { Com glândulas entre o } \\
\text { primeiro par de folíolos }\end{array}$ & & 40 \\
\hline & b. & Sem glândulas & & 41 \\
\hline 40 & a. & $\begin{array}{l}\text { Folíolos com ápice } \\
\text { mucronado, com } 7 \text { a } 10 \text { jugas, } \\
\text { estípulas aristadas } \\
\text { persistentes }\end{array}$ & Senna biflora & \\
\hline
\end{tabular}

Quadro 2 - Chave dicotômica para as espécies arbustivo-arbóreas da E. E. dos Caetetus. 


\begin{tabular}{|c|c|c|c|c|}
\hline & b. & $\begin{array}{l}\text { Folíolos com ápice } \\
\text { arredondado, com } 4 \text { a } 6 \text { jugas, } \\
\text { estípulas caducas }\end{array}$ & Senna pendula & \\
\hline \multirow[t]{2}{*}{41} & a. & Bordo serreado & Diatenopteryx sorbifolia & \\
\hline & b. & Bordo liso & & 42 \\
\hline \multirow[t]{2}{*}{42} & a. & $\begin{array}{l}\text { Folíolos oblongos, ápice } \\
\text { obtuso, cerca de } 20 \text { jugas, } \\
\text { menores que } 4 \mathrm{~cm} \text { de } \\
\text { comprimento }\end{array}$ & Cassia ferruginea & \\
\hline & b. & $\begin{array}{l}\text { Folíolos lanceolados, ápice } \\
\text { agudo, maiores que } 5 \mathrm{~cm} \text { de } \\
\text { comprimento }\end{array}$ & & 43 \\
\hline \multirow[t]{2}{*}{43} & a. & $\begin{array}{l}\text { Folíolos pilosos, de base } \\
\text { arredondada }\end{array}$ & Cedrella fissilis & \\
\hline & b. & $\begin{array}{l}\text { Folíolos glabros, fortemente } \\
\text { assimétricos, base aguda }\end{array}$ & Cabralea canjerana & \\
\hline \multirow[t]{2}{*}{44} & a. & Folíolo sub-terminal & & 45 \\
\hline & b. & Foliolo terminal & & 57 \\
\hline \multirow[t]{2}{*}{45} & a. & $\begin{array}{l}\text { Glândulas translúcidas } \\
\text { imersas no limbo }\end{array}$ & & 46 \\
\hline & b. & Sem esta característica & & 47 \\
\hline \multirow[t]{2}{*}{46} & a. & $\begin{array}{l}\text { Folíolos cartáceos, nervação } \\
\text { terciária nítida na face } \\
\text { superior, glândulas de } \\
\text { discódes à elípsoides e } \\
\text { poucas alongadas }\end{array}$ & Copaifera langsdorffii & \\
\hline & b. & $\begin{array}{l}\text { Folíolos membranáceos, } \\
\text { nervação terciária inconspícua } \\
\text { na face superior, glândulas } \\
\text { arredondadas e alongadas em } \\
\text { forma de traços }\end{array}$ & Myroxyllum peruiferum & \\
\hline \multirow[t]{2}{*}{47} & a. & $\begin{array}{l}\text { Bordos miudamente } \\
\text { serreados, nervuras } \\
\text { secundárias ascendentes até } \\
\text { próximo ao ápice } \\
\end{array}$ & Holocalyx balansae & \\
\hline & b. & Bordo liso & & 48 \\
\hline \multirow[t]{2}{*}{48} & a. & Folíolos elípticos a oblongos & & 49 \\
\hline & b. & Folíolos lanceolados & & 53 \\
\hline
\end{tabular}

Quadro 2 - Chave dicotômica para as espécies arbustivo-arbóreas da E. E. dos Caetetus. 


\begin{tabular}{|c|c|c|c|c|}
\hline 49 & a. & Folíolos lustrosos & & 50 \\
\hline & b. & Folíolos opacos & & 51 \\
\hline 50 & a. & Ráqui canaliculada & Platypodium elegans & \\
\hline & b. & Ráqui cilíndrica & Dalbergia frutescens & \\
\hline 51 & a. & Plantas inermes & Swetia fruticosa & \\
\hline & b. & Plantas armadas & & 52 \\
\hline 52 & a. & $\begin{array}{l}\text { Estípulas persistentes na } \\
\text { forma de espinhos curtos até } \\
0,5 \mathrm{~cm} \text { de comprimento. } \\
\text { Folíolos oblongos, } \\
\text { emarginados de } 1 \text { a } 2 \mathrm{~cm} \text { de } \\
\text { comprimento e } 0,4 \mathrm{~cm} \text { de } \\
\text { largura }\end{array}$ & Machaerium hirtum & \\
\hline & b. & $\begin{array}{l}\text { Estípulas persistentes na } \\
\text { forma de espinhos longos, } \\
\text { maiores que } 2 \mathrm{~cm} \text {, ou } \\
\text { ausentes. Folíolos oblongos- } \\
\text { elípticos, ápice arredondado, } \\
\text { raramente emarginados, de } 3 \\
\text { a } 5 \mathrm{~cm} \text { de comprimento e de } 1 \\
\text { a } 2,5 \mathrm{~cm} \text { de largura }\end{array}$ & Machaerium nictitans & \\
\hline 53 & a. & Folíolos simétricos & & 54 \\
\hline & b. & $\begin{array}{l}\text { Folíolos assimétricos ou } \\
\text { levemente assimétricos }\end{array}$ & & 55 \\
\hline 54 & a. & $\begin{array}{l}\text { Folíolos opacos, glabros, } \\
\text { ápice emarginado }\end{array}$ & Machaerium stipitatum & \\
\hline & b. & $\begin{array}{l}\text { Folíolos lustrosos, ápice } \\
\text { rostrado, com pilosidade } \\
\text { ocrácea e glabrescente }\end{array}$ & Machaerium brasiliensis & \\
\hline 55 & a. & $\begin{array}{l}\text { Folíolos brilhantes na face } \\
\text { superior, primeiro par de } \\
\text { folíolos com base } \\
\text { arredondada }\end{array}$ & & 56 \\
\hline & b. & $\begin{array}{l}\text { Folíolos opacos em ambas as } \\
\text { faces, primeiro par de folíolos } \\
\text { com base aguda }\end{array}$ & & 57 \\
\hline 56 & a. & $\begin{array}{l}\text { Folíolos pilosos na face } \\
\text { inferior, oval-lanceolados a } \\
\text { falciformes, base arredondada } \\
\text { a cordada em todos os } \\
\text { folíolos }\end{array}$ & Cedrella fissilis & \\
\hline
\end{tabular}

Quadro 2 - Chave dicotômica para as espécies arbustivo-arbóreas da E. E. dos Caetetus. 


\begin{tabular}{|c|c|c|c|c|}
\hline & b. & $\begin{array}{l}\text { Folíolos glabros em ambas as } \\
\text { faces, ovais a lanceolados, } \\
\text { base arredondada no primeiro } \\
\text { par de folíolos e aguda nos } \\
\text { demais }\end{array}$ & Picramnia warmigiana & \\
\hline \multirow[t]{2}{*}{57} & a. & $\begin{array}{l}\text { Folíolos fortemente } \\
\text { assimétricos, geralmente mais } \\
\text { de } 20 \text { folíolos, folíolo apical } \\
\text { lanceolado, menor ou igual } \\
\text { aos demais }\end{array}$ & Cabralea canjerana & \\
\hline & b. & $\begin{array}{l}\text { Folíolos levemente } \\
\text { assimétricos, geralmente } \\
\text { menos de } 20 \text { folíolos, folíolo } \\
\text { apical oblanceolado, maior } \\
\text { que os demais }\end{array}$ & Trichilia catigua & \\
\hline \multirow[t]{2}{*}{58} & a. & $\begin{array}{l}\text { Presença de glândulas } \\
\text { translúcidas imersas no limbo }\end{array}$ & & 59 \\
\hline & b. & $\begin{array}{l}\text { Ausência de glândulas } \\
\text { imersas no limbo }\end{array}$ & & 65 \\
\hline \multirow[t]{2}{*}{59} & a. & Bordo liso & & 60 \\
\hline & b. & Bordo serreado crenado & & 61 \\
\hline \multirow[t]{2}{*}{60} & a. & $\begin{array}{l}\text { Foliolos cartáceos a } \\
\text { coriáceos, elíptico- } \\
\text { lanceolados, ápice } \\
\text { arredondado e emarginado }\end{array}$ & Pilocarpus pennatifolius & \\
\hline & b. & $\begin{array}{l}\text { Folíolos membranáceos, } \\
\text { lanceolados, ápice agudo }\end{array}$ & Trichilia elegans & \\
\hline \multirow[t]{2}{*}{61} & a. & Ráqui alada & Zanthoxyllum fagara & \\
\hline & b. & Ráqui não alada & & 62 \\
\hline \multirow[t]{2}{*}{62} & a. & Folha com 5 a 9 folíolos & Zanthoxyllum pohlianum & \\
\hline & b. & Folha com mais de 9 folíolos & & 63 \\
\hline \multirow[t]{2}{*}{63} & a. & Folíolos glabros & & 64 \\
\hline & b. & Folíolos estrelado-pilosos & Zanthoxyllum rhoifolium & \\
\hline \multirow[t]{2}{*}{64} & a. & Folíolos com base reflexa & Zanthoxyllum caribaeum & \\
\hline & b. & Folíolos com base não reflexa & Zanthoxyllum rugosum & \\
\hline \multirow[t]{2}{*}{65} & a. & Bordo serreado & & 66 \\
\hline & b. & Bordo liso & & 68 \\
\hline
\end{tabular}

Quadro 2 - Chave dicotômica para as espécies arbustivo-arbóreas da E. E. dos Caetetus. 


\begin{tabular}{|c|c|c|c|c|}
\hline \multirow[t]{2}{*}{66} & a. & $\begin{array}{l}\text { Folíolos coriáceos, pilosos, } \\
\text { assimétricos, serreados } \\
\text { apenas na metade terminal }\end{array}$ & Roupala brasiliensis & \\
\hline & b. & $\begin{array}{l}\text { Folíolos membranáceos, } \\
\text { glabros ou esparsamente } \\
\text { pilosos ao longo da nervura } \\
\text { principal, serreados em todo o } \\
\text { bordo }\end{array}$ & & 67 \\
\hline \multirow[t]{2}{*}{67} & a. & $\begin{array}{l}\text { Folíolo oval a oblongo- } \\
\text { lanceolados, ápice rostrado, } \\
\text { base arredondada, de } 5 \text { a } 10 \\
\text { cm de comprimento }\end{array}$ & Astronium graveolens & \\
\hline & b. & $\begin{array}{l}\text { Folíolos lanceolados, ápice } \\
\text { agudo, base aguda, de } 1 \text { a } 6 \\
\text { cm de comprimento }\end{array}$ & Diatenopteryx sorbifolia & \\
\hline \multirow[t]{2}{*}{68} & a. & $\begin{array}{l}\text { Folíolos discolores, } \\
\text { densamente pilosos na face } \\
\text { inferior, base arredondada- } \\
\text { cordada, oblongos a elípticos }\end{array}$ & $\begin{array}{l}\text { Centrolobium } \\
\text { tomentosum }\end{array}$ & \\
\hline & b. & Folíolos concolores & & 69 \\
\hline \multirow[t]{2}{*}{69} & a. & Presença de domácias & Trichilia casaretti & \\
\hline & b. & Ausência de domácias & & 70 \\
\hline \multirow[t]{2}{*}{70} & a. & $\begin{array}{l}\text { Folíolos oblongo-elípticos, } \\
\text { ápice obtuso a arredondado, } \\
\text { nervuras secundárias } \\
\text { paralelas numerosas, } \\
\text { salientes na face inferior do } \\
\text { limbo }\end{array}$ & Ormosia arborea & \\
\hline & b. & $\begin{array}{l}\text { Folíolos lanceolados ou ovais- } \\
\text { lanceolados, ápice agudo }\end{array}$ & & 71 \\
\hline \multirow[t]{2}{*}{71} & a. & $\begin{array}{l}\text { Nervação secundária } \\
\text { inconspícua }\end{array}$ & Tapirira guianensis & \\
\hline & b. & Nervação secundária evidente & & 72 \\
\hline \multirow[t]{2}{*}{72} & a. & $\begin{array}{l}\text { Pilosidade presente ao longo } \\
\text { das nervuras na face inferior } \\
\text { do limbo, foliolos com } 3 \text { a } 8 \\
\text { cm de comprimento }\end{array}$ & Lonchocarpus cultratus & \\
\hline & b. & $\begin{array}{l}\text { Pilosidade ausente nos } \\
\text { folíolos }\end{array}$ & & 73 \\
\hline
\end{tabular}

Quadro 2 - Chave dicotômica para as espécies arbustivo-arbóreas da E. E. dos Caetetus. 


\begin{tabular}{|c|c|c|c|c|}
\hline \multirow[t]{2}{*}{73} & a. & $\begin{array}{l}\text { Folíolos cartáceos, } \\
\text { desprendendo odor de } \\
\text { terebintina quando macerados }\end{array}$ & Protium heptaphyllum & \\
\hline & b. & $\begin{array}{l}\text { Folíolos membranáceos, sem } \\
\text { odor característico }\end{array}$ & Trichilia palida & \\
\hline \multirow[t]{2}{*}{74} & a. & Folhas opostas & Jacaranda micrantha & \\
\hline & b. & Folhas alternas & & 75 \\
\hline \multirow[t]{2}{*}{75} & a. & $\begin{array}{l}\text { Ausência de glândulas na } \\
\text { ráqui }\end{array}$ & & 76 \\
\hline & b. & $\begin{array}{l}\text { Presença de glândulas na } \\
\text { ráqui }\end{array}$ & & 77 \\
\hline \multirow[t]{2}{*}{76} & a. & $\begin{array}{l}\text { Pilosidade ferugínea na ráqui } \\
\text { e ramos jovens, estípulas } \\
\text { filiformes caducas }\end{array}$ & Peltophorum dubium & \\
\hline & b. & $\begin{array}{l}\text { Pilosidade esbranquiçada nos } \\
\text { ramos e na folha, estípulas } \\
\text { foliáceas }\end{array}$ & Calliandra foliolosa & \\
\hline \multirow[t]{2}{*}{77} & a. & $\begin{array}{l}\text { Presença de glândulas no } \\
\text { pecíolo comum }\end{array}$ & & 78 \\
\hline & b. & $\begin{array}{l}\text { Ausência de glândulas no } \\
\text { pecíolo comum }\end{array}$ & $\begin{array}{l}\text { Enterolobium } \\
\text { contortisiliquum }\end{array}$ & \\
\hline \multirow[t]{2}{*}{78} & a. & $\begin{array}{l}\text { Glândula elíptica no pecíolo } \\
\text { comum }\end{array}$ & Parapiptadenia rigida & \\
\hline & b. & $\begin{array}{l}\text { Glândula discóide no pecíolo } \\
\text { comum }\end{array}$ & & 79 \\
\hline \multirow[t]{2}{*}{79} & a. & $\begin{array}{l}\text { Ráqui da pina sem } \\
\text { prolongamento após o último } \\
\text { par de folíolos }\end{array}$ & Acacia polyphylla & \\
\hline & b. & $\begin{array}{l}\text { Ráqui da pina prolongando-se } \\
\text { além do último par de folíolos }\end{array}$ & & 80 \\
\hline \multirow[t]{2}{*}{80} & a. & Planta armada & Piptadenia gonoacantha & \\
\hline & b. & Planta inerme & & 81 \\
\hline \multirow[t]{2}{*}{81} & a. & $\begin{array}{l}\text { Folhas com } 5 \text { a } 7 \text { pares de } \\
\text { pinas }\end{array}$ & Albizia hassleri & \\
\hline & b. & $\begin{array}{l}\text { Folhas com } 8 \text { a } 10 \text { pares de } \\
\text { pinas }\end{array}$ & Albizia polycephala & \\
\hline \multirow[t]{2}{*}{82} & a. & $\begin{array}{l}\text { Folhas opostas, sub-opostas } \\
\text { ou verticiladas }\end{array}$ & & 83 \\
\hline & b. & $\begin{array}{l}\text { Folhas alternas espiraladas } \\
\text { ou dísticas }\end{array}$ & & 136 \\
\hline
\end{tabular}

Quadro 2 - Chave dicotômica para as espécies arbustivo-arbóreas da E. E. dos Caetetus. 


\begin{tabular}{|c|c|c|c|c|}
\hline \multirow[t]{2}{*}{83} & a. & $\begin{array}{l}\text { Pecíolo articulado na conexão } \\
\text { com o limbo, estípulas } \\
\text { fimbriadas no ápice }\end{array}$ & Sloanea monosperma & \\
\hline & b. & Sem estes caracteres & & 84 \\
\hline \multirow[t]{2}{*}{84} & a.* & Folhas verticiladas & & 85 \\
\hline & b. ${ }^{*}$ & $\begin{array}{l}\text { Folhas opostas ou sub- } \\
\text { opostas }\end{array}$ & & 87 \\
\hline \multirow[t]{2}{*}{85} & a. & Folhas glabras, com látex & Rauvolfia sellowii M. Arg. & \\
\hline & b. & Folhas pilosas, sem látex & & 86 \\
\hline \multirow[t]{2}{*}{86} & a. & $\begin{array}{l}\text { Folhas discolores, com } \\
\text { glândulas translúcidas no } \\
\text { limbo }\end{array}$ & Eugenia $s p$ & \\
\hline & b. & $\begin{array}{l}\text { Folhas concolores, sem } \\
\text { glândulas }\end{array}$ & Amaioua intermedia & \\
\hline \multirow[t]{2}{*}{87} & $\begin{array}{l}a_{*}^{* *} \\
{ }^{*}\end{array}$ & $\begin{array}{l}\text { Folhas opostas com glândulas } \\
\text { translúcidas no limbo }\end{array}$ & & 88 \\
\hline & b. & $\begin{array}{l}\text { Folhas opostas, sem } \\
\text { glândulas translúcidas no } \\
\text { limbo }\end{array}$ & & 108 \\
\hline \multirow[t]{2}{*}{88} & a. & $\begin{array}{l}\text { Nervuras secundárias } \\
\text { anastomosantes, não } \\
\text { terminando em nervura } \\
\text { coletora }\end{array}$ & & 89 \\
\hline & b. & $\begin{array}{l}\text { Nervura secundárias } \\
\text { terminando em nervura } \\
\text { coletora }\end{array}$ & & 93 \\
\hline \multirow[t]{2}{*}{89} & a. & $\begin{array}{l}\text { Folhas pilosas, com nervação } \\
\text { saliente na face inferior }\end{array}$ & $\begin{array}{l}\text { Campomanesia } \\
\text { guazumaefolia }\end{array}$ & \\
\hline & b. & $\begin{array}{l}\text { Folhas glabras, sem nervuras } \\
\text { salientes na face inferior }\end{array}$ & & 90 \\
\hline \multirow[t]{2}{*}{90} & a. & $\begin{array}{l}\text { Folhas cartáceas a sub- } \\
\text { coriáceas }\end{array}$ & & 91 \\
\hline & b. & Folhas membranáceas & & 92 \\
\hline 91 & a. & $\begin{array}{l}\text { Folhas de elípticas a } \\
\text { espatuladas, } 8 \text { a } 20 \mathrm{~cm} \text { de } \\
\text { comprimento, ápice de obtuso } \\
\text { a arredondado, pecíolo maior } \\
\text { que } 10 \mathrm{~mm}\end{array}$ & Pilocarpus pauciflorus & \\
\hline \multirow[t]{2}{*}{93} & a. & Folhas com ápice apiculado & Myrcianthes pungens & \\
\hline & b. & $\begin{array}{l}\text { Folhas com ápice não } \\
\text { apiculado }\end{array}$ & & 94 \\
\hline
\end{tabular}

Quadro 2 - Chave dicotômica para as espécies arbustivo-arbóreas da E. E. dos Caetetus. 


\begin{tabular}{|c|c|c|c|c|}
\hline \multirow[t]{2}{*}{94} & a. & $\begin{array}{l}\text { Folhas curto-pecioladas, base } \\
\text { cordada }\end{array}$ & Blepharocalyx salicifolius & \\
\hline & b. & $\begin{array}{l}\text { Folhas pecioladas, base } \\
\text { aguda a obtusa }\end{array}$ & & 95 \\
\hline \multirow[t]{2}{*}{95} & a. & $\begin{array}{l}\text { Pilosidade presente nos } \\
\text { ramos jovens }\end{array}$ & & 96 \\
\hline & b. & $\begin{array}{l}\text { Pilosidade ausente nos ramos } \\
\text { jovens }\end{array}$ & & 99 \\
\hline \multirow[t]{2}{*}{96} & a. & Folhas coriáceas ou cartáceas & & 97 \\
\hline & b. & Folhas membranáceas & & 98 \\
\hline \multirow[t]{2}{*}{97} & a. & $\begin{array}{l}\text { Folhas com glândulas } \\
\text { impressas na face superior do } \\
\text { limbo, comprimento inferior a } \\
4 \mathrm{~cm}\end{array}$ & Myrcia bella & \\
\hline & b. & $\begin{array}{l}\text { Folhas com glândulas não } \\
\text { impressas na face superior do } \\
\text { limbo, comprimento superior a } \\
4 \mathrm{~cm}\end{array}$ & Calypthranthes concinna & \\
\hline \multirow[t]{2}{*}{98} & a. & $\begin{array}{l}\text { Folhas rostradas, pilosidade } \\
\text { esbranquiçada }\end{array}$ & Myrcia fallax & \\
\hline & b. & $\begin{array}{l}\text { Folhas não rostradas, } \\
\text { pilosiodade ferrugínea }\end{array}$ & Myrciaria sp 2 & \\
\hline \multirow[t]{2}{*}{99} & a. & Folhas cartáceas & & 100 \\
\hline & b. & Folhas membranáceas & & 101 \\
\hline \multirow[t]{2}{*}{100} & a. & $\begin{array}{l}\text { Margem revoluta, } 4 \text { a } 8 \mathrm{~cm} \text { de } \\
\text { comprimento }\end{array}$ & Eugenia blastantha & \\
\hline & b. & $\begin{array}{l}\text { Margem não revoluta, } 8 \text { a } 14 \\
\mathrm{~cm} \text { de comprimento }\end{array}$ & Syzygium cumini & \\
\hline \multirow[t]{2}{*}{101} & a. & Ápice rostrado & & 102 \\
\hline & b. & Apice agudo ou acuminado & & 105 \\
\hline \multirow[t]{2}{*}{102} & a. & $\begin{array}{l}\text { Uma única nervura coletora } \\
\text { na margem do limbo, } 2 \text { a } 4 \mathrm{~cm} \\
\text { de largura por } 6 \text { a } 9 \mathrm{~cm} \text { de } \\
\text { comprimento }\end{array}$ & & 103 \\
\hline & b. & $\begin{array}{l}\text { Duas nervuras coletoras, } \\
\text { sendo a externa menos nítida }\end{array}$ & & 104 \\
\hline 103 & a. & $\begin{array}{l}\text { Limbo com } 2 \text { a } 5 \mathrm{~cm} \text { de } \\
\text { comprimento por } 1 \text { a } 2 \mathrm{~cm} \text { de } \\
\text { largura }\end{array}$ & Eugenia sp 3 & \\
\hline
\end{tabular}

Quadro 2 - Chave dicotômica para as espécies arbustivo-arbóreas da E. E. dos Caetetus. 


\begin{tabular}{|c|c|c|c|c|}
\hline 105 & a. & Bordo ondulado & Myrciaria sp 1 & \\
\hline & b. & Bordo plano & & 106 \\
\hline 106 & a. & $\begin{array}{l}\text { Nervação secundária } \\
\text { congesta (mais de } 10 \\
\text { nervuras/cm), árvore de casca } \\
\text { lisa }\end{array}$ & & 107 \\
\hline & b. & $\begin{array}{l}\text { Nervação secundária laxa } \\
\text { (menos de } 10 \text { nervuras/cm), } \\
\text { ramos jovens avermelhados, } \\
\text { árvore de casca sulcada }\end{array}$ & Eugenia moraviana & \\
\hline 107 & a. & $\begin{array}{l}\text { Comprimento das folhas } \\
\text { geralmente inferior a } 3 \mathrm{~cm}\end{array}$ & Myrciaria ciliolata & \\
\hline & b. & $\begin{array}{l}\text { Comprimento das folhas } \\
\text { superior a } 3 \mathrm{~cm}\end{array}$ & $\begin{array}{l}\text { Neomythranthes } \\
\text { glomerata }\end{array}$ & \\
\hline 108 & a. & $\begin{array}{l}\text { Pecíolos fundidos em bainha } \\
\text { ocreiforme }\end{array}$ & Hedyosmum brasiliense & \\
\hline & b. & Pecíolos não fundidos & & 109 \\
\hline 109 & a. & Com estípulas interpeciolares & & 110 \\
\hline & b. & Sem estípulas interpeciolares & & 114 \\
\hline 110 & a. & Planta armada & & 111 \\
\hline & b. & Planta inerme & & 112 \\
\hline 111 & a. & $\begin{array}{l}\text { Espinhos em ângulo agudo } \\
\text { em relação ao ramo, nervação } \\
\text { secundária arqueada }\end{array}$ & Chomelia pohliana & \\
\hline & b. & $\begin{array}{l}\text { Espinhos em ângulo reto em } \\
\text { relação ao ramo, nervação } \\
\text { secundária não arqueada }\end{array}$ & Randia armata & \\
\hline 112 & a. & Folhas pilosas & Coutarea hexandra & \\
\hline & b. & Folhas glabras & & 113 \\
\hline 113 & a. & $\begin{array}{l}\text { Nervação secundária } \\
\text { peniparalelinérvea }\end{array}$ & Ixora venulosa & \\
\hline & b. & $\begin{array}{l}\text { Nervação secundária não } \\
\text { peniparalelinérvea, presença } \\
\text { de domácias }\end{array}$ & Rudgea jasminoides & \\
\hline 114 & a. & $\begin{array}{l}\text { Nervuras secundárias } \\
\text { curvinérvias, paralelas ao } \\
\text { bordo, estendendo-se até o } \\
\text { ápice }\end{array}$ & & 115 \\
\hline & b. & $\begin{array}{l}\text { Nervuras secundárias não } \\
\text { curvinérveas, direcionadas } \\
\text { para a margem }\end{array}$ & & 121 \\
\hline
\end{tabular}

Quadro 2 - Chave dicotômica para as espécies arbustivo-arbóreas da E. E. dos Caetetus. 


\begin{tabular}{|c|c|c|c|c|}
\hline 115 & a. & Limbo decorrente no pecíolo & Miconia discolor & \\
\hline & b. & $\begin{array}{l}\text { Limbo não decorrente no } \\
\text { pecíolo }\end{array}$ & & 116 \\
\hline \multirow[t]{2}{*}{116} & a. & $\begin{array}{l}\text { Presença de domácias na } \\
\text { base das nervuras } \\
\text { secundárias }\end{array}$ & Miconia hymenonervia & \\
\hline & b. & Ausência de domácias & & 117 \\
\hline \multirow[t]{2}{*}{117} & a. & Margem inteira a sub-inteira & & 118 \\
\hline & b. & Margem crenada a dentada & & 119 \\
\hline \multirow[t]{2}{*}{118} & a. & $\begin{array}{l}\text { Ápice agudo, pilosidade } \\
\text { ocrácea nos ramos jovens, } \\
\text { comprimento } 15 \text { a } 20 \mathrm{~cm} \text {, } \\
\text { largura } 6 \text { a } 12 \mathrm{~cm}\end{array}$ & Miconia calvescens & \\
\hline & b. & $\begin{array}{l}\text { Ápice agudo-atenuado a } \\
\text { rostrado, ramos } \\
\text { glabrescentes, } 7 \text { a } 12 \mathrm{~cm} \text { de } \\
\text { comprimento, } 2 \text { a } 3 \mathrm{~cm} \text { de } \\
\text { largura }\end{array}$ & Miconia sp 1 & \\
\hline \multirow[t]{2}{*}{119} & a. & $\begin{array}{l}\text { Ramos e folhas pilosos em } \\
\text { ambas as faces }\end{array}$ & Leandra sp & \\
\hline & b. & $\begin{array}{l}\text { Ramos e folhas glabros a } \\
\text { glabrescentes }\end{array}$ & & 120 \\
\hline \multirow[t]{2}{*}{120} & a. & $\begin{array}{l}\text { Bordo laxo-serreado, dentes } \\
\text { curvos, cerca de } 3 \mathrm{~mm} \text { de } \\
\text { comprimento, } 13 \text { a } 20 \mathrm{~cm} \text { de } \\
\text { comprimento, } 2 \text { a } 3 \mathrm{~cm} \text { de } \\
\text { largura }\end{array}$ & Miconia sp 2 & \\
\hline & b. & $\begin{array}{l}\text { Bordo crenado, } 20 \text { a } 25 \mathrm{~cm} \text { de } \\
\text { comprimento, } 6 \text { a } 7 \mathrm{~cm} \text { de } \\
\text { largura }\end{array}$ & Miconia latecrenata & \\
\hline \multirow[t]{2}{*}{121} & a. & $\begin{array}{l}\text { Presença de glândulas } \\
\text { côncavas, elípticas, na base } \\
\text { do limbo }\end{array}$ & $\begin{array}{l}\text { Cytharexyllum } \\
\text { myrianthum }\end{array}$ & \\
\hline & b. & $\begin{array}{l}\text { Ausência de glândulas deste } \\
\text { tipo }\end{array}$ & & 122 \\
\hline \multirow[t]{2}{*}{122} & a. & $\begin{array}{l}\text { Ramos quadrangulares ou } \\
\text { achatado }\end{array}$ & Aegiphylla sellowiana & \\
\hline & b. & Ramos não quadrangulares & & 123 \\
\hline \multirow[t]{2}{*}{123} & a. & Ramificação dicotômica & & 124 \\
\hline & b. & Ramificação não dicotômica & & 128 \\
\hline
\end{tabular}

Quadro 2 - Chave dicotômica para as espécies arbustivo-arbóreas da E. E. dos Caetetus. 


\begin{tabular}{|c|c|c|c|c|}
\hline \multirow[t]{2}{*}{124} & $a$. & $\begin{array}{l}\text { Folhas elípticas, base } \\
\text { arredondada, } 15 \text { a } 25 \mathrm{~cm} \text { de } \\
\text { comprimento, } 5 \text { a } 8 \text { de } \\
\text { largura, com pilosidade flava } \\
\text { nas folhas e ramos jovens }\end{array}$ & $\begin{array}{l}\text { Calypthranthes } \\
\text { clusiaefolia }\end{array}$ & \\
\hline & b. & $\begin{array}{l}\text { Folhas elíptico-lanceoladas a } \\
\text { lanceoladas, base aguda a } \\
\text { cuneada de menores } \\
\text { dimensões }\end{array}$ & & 125 \\
\hline \multirow[t]{2}{*}{125} & a. & $\begin{array}{l}\text { Ramos ou gemas com } \\
\text { pilosidade ferrugínea }\end{array}$ & & 126 \\
\hline & b. & Sem pilosidade ferrugínea & & 127 \\
\hline \multirow[t]{2}{*}{126} & a. & $\begin{array}{l}\text { Pilosidade somente nas } \\
\text { gemas }\end{array}$ & Guapira opposita & \\
\hline & b. & $\begin{array}{l}\text { Pilosidade nos ramos, nas } \\
\text { gemas e no limbo }\end{array}$ & Guapira hirsuta & \\
\hline \multirow[t]{2}{*}{127} & a. & $\begin{array}{l}\text { Planta com látex abundante, } \\
\text { folha estreito-lanceolada, } 8 \text { a } \\
20 \mathrm{~cm} \text { de comprimento e } 1,5 \\
\text { a } 3 \mathrm{~cm} \text { de largura }\end{array}$ & $\begin{array}{l}\text { Tabernaemontana } \\
\text { hystrix }\end{array}$ & \\
\hline & b. & $\begin{array}{l}\text { Planta sem látex, folha } \\
\text { elíptico-lanceolada, } 6 \text { a } 10 \mathrm{~cm} \\
\text { de comprimento e } 2,5 \text { a } 3,5 \\
\text { cm de largura }\end{array}$ & Calyptrantes concinna & \\
\hline \multirow[t]{2}{*}{128} & a. & $\begin{array}{l}\text { Bordo serreado ou serreado- } \\
\text { crenado }\end{array}$ & & 129 \\
\hline & b. & Bordo liso & & 130 \\
\hline \multirow[t]{2}{*}{129} & a. & $\begin{array}{l}\text { Bordo serreado nos dois } \\
\text { terços posteriores do limbo, } \\
\text { ramos jovens ferrugíneos }\end{array}$ & Mollinedia widgrenii & \\
\hline & b. & $\begin{array}{l}\text { Bordo serreado-crenado, folha } \\
\text { squarrosa na face superior }\end{array}$ & Aloysia virgata & \\
\hline \multirow[t]{2}{*}{130} & a. & $\begin{array}{l}\text { Pilosidade ferrugínea na face } \\
\text { inferior do limbo }\end{array}$ & & 131 \\
\hline & b. & $\begin{array}{l}\text { Glabras ou com outro tipo de } \\
\text { pilosidade }\end{array}$ & & 132 \\
\hline 131 & a. & $\begin{array}{l}\text { Ramos jovens achatados, } \\
\text { folhas lanceoladas, tênue- } \\
\text { acuminadas, base cuneada, } \\
20 \text { a } 30 \mathrm{~cm} \text { de comprimento, } 4 \\
\text { a } 8 \mathrm{~cm} \text { de largura }\end{array}$ & Nectandra oppositifolia & \\
\hline
\end{tabular}

Quadro 2 - Chave dicotômica para as espécies arbustivo-arbóreas da E. E. dos Caetetus. 


\begin{tabular}{|c|c|c|c|c|}
\hline \multirow[t]{2}{*}{132} & a. & $\begin{array}{l}\text { Folhas coriáceas, } \\
\text { peniparalelinérveas, elíptico- } \\
\text { lanceoladas, com látex } \\
\text { amarelo }\end{array}$ & Callophyllum brasiliense & \\
\hline & b. & $\begin{array}{l}\text { Folhas não coriaceas, sem } \\
\text { látex }\end{array}$ & & 133 \\
\hline \multirow[t]{2}{*}{133} & a. & $\begin{array}{l}\text { Folhas com pontuações } \\
\text { negras dispersas na face } \\
\text { inferior do limbo }\end{array}$ & $\begin{array}{l}\text { Rhamnidium } \\
\text { elaeocarpum }\end{array}$ & \\
\hline & b. & $\begin{array}{l}\text { Folhas sem pontuações } \\
\text { negras }\end{array}$ & & 134 \\
\hline \multirow[t]{2}{*}{134} & a. & $\begin{array}{l}\text { Folhas com duas glândulas no } \\
\text { terço inferior do limbo, } \\
\text { próximas à nervura principal }\end{array}$ & Bunchosia pallescens & \\
\hline & b. & Folhas sem glândulas & & 135 \\
\hline \multirow[t]{2}{*}{135} & a. & $\begin{array}{l}\text { Folhas congestas, opostas } \\
\text { cruzadas, sem odor }\end{array}$ & Pisonia ambigua & \\
\hline & b. & $\begin{array}{l}\text { Folhas opostas dísticas, } \\
\text { laxas, com odor desagradável }\end{array}$ & Siparuna guianensis & \\
\hline \multirow[t]{2}{*}{136} & a. & Bordo espinhoso & & 137 \\
\hline & b. & $\begin{array}{l}\text { Bordo não espinhoso } \\
\text { (inclusive denteado, serreado, } \\
\text { etc.) }\end{array}$ & & 139 \\
\hline \multirow[t]{2}{*}{137} & a. & $\begin{array}{l}\text { Folha espatulada, ápice } \\
\text { arredondado, com látex } \\
\text { abundante, comprimento } 15 \text { a } \\
40 \mathrm{~cm} \text {, largura } 3 \text { a } 10 \mathrm{~cm}\end{array}$ & Pachystroma longifolium & \\
\hline & b. & $\begin{array}{l}\text { Folhas lanceoladas, ápice } \\
\text { agudo }\end{array}$ & & 138 \\
\hline \multirow[t]{2}{*}{138} & a. & $\begin{array}{l}\text { Nervuras secundárias } \\
\text { proeminentes, } \\
\text { anastomosantes, com a } \\
\text { nervação do espinho saindo } \\
\text { de cada par de nervuras, } \\
\text { planta com látex }\end{array}$ & Sorocea bonplandii & \\
\hline & b. & $\begin{array}{l}\text { Nervuras secundárias não } \\
\text { proeminentes, não } \\
\text { anastomosantes, sem látex, } \\
\text { nervação secundária } \\
\text { terminando diretamente no } \\
\text { espinho }\end{array}$ & Maytenus aquifolium & \\
\hline
\end{tabular}

Quadro 2 - Chave dicotômica para as espécies arbustivo-arbóreas da E. E. dos Caetetus. 


\begin{tabular}{|c|c|c|c|c|}
\hline 139 & a. & Ramos com ramentas & Erythroxyllum deciduum & \\
\hline & b. & Ramos sem ramentas & & 140 \\
\hline \multirow[t]{2}{*}{140} & a. & $\begin{array}{l}\text { Folhas com glândulas } \\
\text { translúcidas imersas no limbo }\end{array}$ & & 141 \\
\hline & b. & $\begin{array}{l}\text { Folhas sem glândulas } \\
\text { translúcidas no limbo ou com } \\
\text { outro tipo de glândulas (não } \\
\text { confundir com pontos } \\
\text { translúcidos do parênquima) }\end{array}$ & & 144 \\
\hline \multirow{2}{*}{141} & a. & Glândulas em forma de ponto & & 142 \\
\hline & b. & Glândulas em forma de traços & & 143 \\
\hline \multirow[t]{2}{*}{142} & a. & $\begin{array}{l}\text { Espessamento evidente na } \\
\text { ligação entre o pecíolo e o } \\
\text { limbo }\end{array}$ & Esenbeckia grandiflora & \\
\hline & b. & $\begin{array}{l}\text { Sem espessamento evidente } \\
\text { entre o peciolo e o limbo, } \\
\text { folhas frescas com forte odor }\end{array}$ & Pilocarpus pauciflorus & \\
\hline \multirow[t]{2}{*}{143} & a. & $\begin{array}{l}\text { Glândulas dispersas por todo } \\
\text { o limbo }\end{array}$ & Casearia sylvestris & \\
\hline & b. & $\begin{array}{l}\text { Glândulas somente no bordo } \\
\text { do limbo }\end{array}$ & Casearia obliqua & \\
\hline \multirow[t]{2}{*}{144} & a. & $\begin{array}{l}\text { Ramos com estípulas } \\
\text { envolvendo a gema apical (ex: } \\
\text { Ficus, Cecropia) }\end{array}$ & & 145 \\
\hline & b. & $\begin{array}{l}\text { Ramos com outro tipo de } \\
\text { estípula, geralmente em pare } \\
\text { na base dos pecíolos, ou sem } \\
\text { estípulas }\end{array}$ & & 158 \\
\hline \multirow[t]{2}{*}{145} & a. & Folhas palmatipartidas & & 146 \\
\hline & b. & Folhas inteiras & & 147 \\
\hline \multirow[t]{2}{*}{146} & a. & Estípulas avermelhadas & Cecropia glaziouii & \\
\hline & b. & Estípulas esbranquiçadas & Cecropia pachystachya & \\
\hline \multirow[t]{2}{*}{147} & a. & $\begin{array}{l}\text { Bordo serreado, látex } \\
\text { amarelado, planta geralmente } \\
\text { com espinhos }\end{array}$ & Maclura tinctoria & \\
\hline & b. & Bordo liso, sem látex & & 148 \\
\hline 148 & a. & $\begin{array}{l}\text { Presença de pontuações } \\
\text { pardas ou negras ou estrias } \\
\text { negras na face inferior do } \\
\text { limbo }\end{array}$ & & 149 \\
\hline
\end{tabular}

Quadro 2 - Chave dicotômica para as espécies arbustivo-arbóreas da E. E. dos Caetetus. 


\begin{tabular}{|c|c|c|c|c|}
\hline 139 & a. & Ramos com ramentas & Erythroxyllum deciduum & \\
\hline & b. & Ramos sem ramentas & & 140 \\
\hline \multirow[t]{2}{*}{140} & a. & $\begin{array}{l}\text { Folhas com glândulas } \\
\text { translúcidas imersas no limbo }\end{array}$ & & 141 \\
\hline & b. & $\begin{array}{l}\text { Folhas sem glândulas } \\
\text { translúcidas no limbo ou com } \\
\text { outro tipo de glândulas (não } \\
\text { confundir com pontos } \\
\text { translúcidos do parênquima) }\end{array}$ & & 144 \\
\hline \multirow[t]{2}{*}{141} & a. & Glândulas em forma de ponto & & 142 \\
\hline & b. & Glândulas em forma de traços & & 143 \\
\hline \multirow[t]{2}{*}{142} & a. & $\begin{array}{l}\text { Espessamento evidente na } \\
\text { ligação entre o peciolo e o } \\
\text { limbo }\end{array}$ & Esenbeckia grandiflora & \\
\hline & b. & $\begin{array}{l}\text { Sem espessamento evidente } \\
\text { entre o peciolo e o limbo, } \\
\text { folhas frescas com forte odor }\end{array}$ & Pilocarpus pauciflorus & \\
\hline \multirow[t]{2}{*}{143} & a. & $\begin{array}{l}\text { Glândulas dispersas por todo } \\
\text { o limbo }\end{array}$ & Casearia sy/vestris & \\
\hline & b. & $\begin{array}{l}\text { Glândulas somente no bordo } \\
\text { do limbo }\end{array}$ & Casearia obliqua & \\
\hline \multirow[t]{2}{*}{144} & a. & $\begin{array}{l}\text { Ramos com estípulas } \\
\text { envolvendo a gema apical (ex: } \\
\text { Ficus, Cecropia) }\end{array}$ & & 145 \\
\hline & b. & $\begin{array}{l}\text { Ramos com outro tipo de } \\
\text { estípula, geralmente em pare } \\
\text { na base dos peciolos, ou sem } \\
\text { estipulas }\end{array}$ & & 158 \\
\hline \multirow[t]{2}{*}{145} & a. & Folhas palmatipartidas & & 146 \\
\hline & b. & Folhas inteiras & & 147 \\
\hline \multirow[t]{2}{*}{146} & a. & Estípulas avermelhadas & Cecropia glaziouii & \\
\hline & b. & Estípulas esbranquiçadas & Cecropia pachystachya & \\
\hline \multirow[t]{2}{*}{147} & a. & $\begin{array}{l}\text { Bordo serreado, látex } \\
\text { amarelado, planta geralmente } \\
\text { com espinhos }\end{array}$ & Maclura tinctoria & \\
\hline & b. & Bordo liso, sem látex & & 148 \\
\hline 148 & a. & $\begin{array}{l}\text { Presença de pontuações } \\
\text { pardas ou negras ou estrias } \\
\text { negras na face inferior do } \\
\text { limbo }\end{array}$ & & 149 \\
\hline
\end{tabular}

Quadro 2 - Chave dicotômica para as espécies arbustivo-arbóreas da E. E. dos Caetetus. 


\begin{tabular}{|c|c|c|c|c|}
\hline & b. & $\begin{array}{l}\text { Ausência de pontuações ou } \\
\text { estrias na face inferior do } \\
\text { limbo }\end{array}$ & & 153 \\
\hline 149 & a. & $\begin{array}{l}\text { Ramos com pilosidade } \\
\text { ocrácea }\end{array}$ & Rapanea ferruginea & \\
\hline \multirow[t]{2}{*}{159} & a. & $\begin{array}{l}\text { Presença de faixa de } \\
\text { pilosidade ferrugínea ao longo } \\
\text { da nervura principal na face } \\
\text { inferior do limbo das folhas } \\
\text { jovens, látex abundante }\end{array}$ & Mabea fistulifera & \\
\hline & b. & Sem estas características & & 160 \\
\hline \multirow[t]{2}{*}{160} & a. & $\begin{array}{l}\text { Presença de glândulas na } \\
\text { folha }\end{array}$ & & 161 \\
\hline & b. & Sem glândulas na folha & & 166 \\
\hline \multirow[t]{2}{*}{161} & a. & $\begin{array}{l}\text { Presença de um par de } \\
\text { glândulas estipitadas na } \\
\text { junção do pecíolo com o limbo }\end{array}$ & & 162 \\
\hline & b. & $\begin{array}{l}\text { Folhas com outro tipo de } \\
\text { glândula }\end{array}$ & & 163 \\
\hline \multirow[t]{2}{*}{162} & a. & $\begin{array}{l}\text { Bordo finamente serreado, } \\
\text { folhas oblongas, } 13 \text { a } 20 \mathrm{~cm} \\
\text { de comprimento e } 3 \text { a } 5 \mathrm{~cm} \text { de } \\
\text { largura }\end{array}$ & Sapium glandulatum & \\
\hline & b. & $\begin{array}{l}\text { Bordo esparsamente } \\
\text { serreado, folhas ovais, } 25 \mathrm{a} \\
40 \mathrm{~cm} \text { de comprimento e } 15 \text { a } \\
20 \mathrm{~cm} \text { de largura }\end{array}$ & Aparistimum cordatum & \\
\hline \multirow[t]{2}{*}{163} & a. & $\begin{array}{l}\text { Folhas elípticas, nervação } \\
\text { simples }\end{array}$ & $\begin{array}{l}\text { Sebastiania } \\
\text { commersoniana }\end{array}$ & \\
\hline & b. & $\begin{array}{l}\text { Folhas ovais, três a cinco } \\
\text { nervuras partindo da base }\end{array}$ & & 164 \\
\hline \multirow[t]{2}{*}{164} & a. & $\begin{array}{l}\text { Limbo levemente lobado, } \\
\text { base arredondada com } \\
\text { glândulas no bordo, estípulas } \\
\text { lineares presentes nos ramos } \\
\text { jovens, cinco nervuras } \\
\text { partindo da base do limbo }\end{array}$ & Heliocarpus americanus & \\
\hline & b. & $\begin{array}{l}\text { Folhas ovais, sem estípulas, } \\
\text { três nervuras partindo da } \\
\text { base, glândulas nas axilas } \\
\text { das nervuras }\end{array}$ & & 165 \\
\hline
\end{tabular}

Quadro 2 - Chave dicotômica para as espécies arbustivo-arbóreas da E. E. dos Caetetus. 


\begin{tabular}{|c|c|c|c|c|}
\hline 165 & a. & Folha pilosa na face inferior & Alchornea glandulosa & \\
\hline & b. & Folhas glabras & Alchornea triplinervia & \\
\hline 166 & a. & $\begin{array}{l}\text { Presença de estípulas } \\
\text { foliáceas }\end{array}$ & Prockia crucis & \\
\hline & b. & Sem este tipo de estípulas & & 167 \\
\hline 167 & a. & Folhas discolores & & 168 \\
\hline & b. & Folhas concolores & & 171 \\
\hline 168 & a. & Folhas uninervadas & & 169 \\
\hline & b. & Folhas trinervadas & & 170 \\
\hline 169 & a. & Pilosidade prateada adpressa & Piptocarpha sellowii & \\
\hline & b. & $\begin{array}{l}\text { Pilosidade ocracea não } \\
\text { adpressa }\end{array}$ & Piptocarpha axillaris & \\
\hline 170 & a. & $\begin{array}{l}\text { Limbo com base aguda a } \\
\text { arredondada, margem } \\
\text { denteada, dentes nitidamente } \\
\text { irregulares, ápice tênue- } \\
\text { acuminado, face superior lisa } \\
\text { ao tato }\end{array}$ & Luehea candicans & \\
\hline & b. & $\begin{array}{l}\text { Limbo com base arredondada } \\
\text { a sub-cordada, margem } \\
\text { denteada, dentes regulares a } \\
\text { ligeiramente irregulares, face } \\
\text { superior áspera ao tato }\end{array}$ & Luehea divaricata & \\
\hline 171 & a. & $\begin{array}{l}\text { Folhas com } 3 \text { ou mais } \\
\text { nervuras partindo da base do } \\
\text { limbo }\end{array}$ & & 172 \\
\hline & b. & $\begin{array}{l}\text { Folhas com uma única } \\
\text { nervura partindo da base }\end{array}$ & & 175 \\
\hline 172 & a. & $\begin{array}{l}\text { Margem largo-serreada, } \\
\text { folhas largo-ovadas a } \\
\text { arredondadas }\end{array}$ & & 173 \\
\hline & b. & $\begin{array}{l}\text { Margem finamente serreada, } \\
\text { folhas oval-lanceoladas }\end{array}$ & & 174 \\
\hline 173 & a. & $\begin{array}{l}\text { Margem irregularmente } \\
\text { serreada, pelos estrelados } \\
\text { esparsos }\end{array}$ & Cristiania macrodon & \\
\hline & b. & $\begin{array}{l}\text { Margem regularmente } \\
\text { serreada, com pelos } \\
\text { urticantes em toda a folha }\end{array}$ & Urera baccifera & \\
\hline 174 & a. & Pelos simples no limbo & Trema micrantha & \\
\hline & b. & Pelos estrelados no limbo & Guazuma ulmifolia & \\
\hline
\end{tabular}

Quadro 2 - Chave dicotômica para as espécies arbustivo-arbóreas da E. E. dos Caetetus. 


\begin{tabular}{|c|c|c|c|c|}
\hline \multirow[t]{2}{*}{175} & a. & $\begin{array}{l}\text { Margem serreada em todo o } \\
\text { limbo (excepcionalmente não } \\
\text { serreada muito próximo à } \\
\text { base) } \\
\text { abaxial }{ }^{*} \text { observar pela face }\end{array}$ & & 176 \\
\hline & b. & $\begin{array}{l}\text { Margem não serreada no } \\
\text { terço inferior do limbo }\end{array}$ & & 179 \\
\hline \multirow[t]{2}{*}{176} & a. & $\begin{array}{l}\text { Folhas esquarrosas na face } \\
\text { superior }\end{array}$ & Cordia superba & \\
\hline & b. & Folhas lisas na face superior & & 177 \\
\hline \multirow[t]{2}{*}{177} & a. & Folhas congestas & Patagonula americana & \\
\hline & b. & Folhas laxas & & 178 \\
\hline \multirow[t]{2}{*}{178} & a. & Folhas cartáceas a coriáceas & & 180 \\
\hline & b. & Folhas membranáceas & Symplocos sp 2 & \\
\hline \multirow[t]{2}{*}{179} & a. & $\begin{array}{l}\text { Folhas longo-pecioladas, } \\
\text { ovais, com pulvino, } \\
\text { irregularmente serreadas, } \\
\text { ápice acuminado, nervação } \\
\text { fortemente oblíqua }\end{array}$ & Roupala brasiliensis & \\
\hline & b. & $\begin{array}{l}\text { Folhas curto pecioladas, } \\
\text { lanceoladas, regularmente } \\
\text { serreadas, ápice agudo }\end{array}$ & Symplocos sp 1 & \\
\hline \multirow[t]{2}{*}{180} & a. & $\begin{array}{l}\text { Folhas persistentes na base } \\
\text { dos ramos jovens }\end{array}$ & & 181 \\
\hline & b. & $\begin{array}{l}\text { Sem folhas persistentes na } \\
\text { base dos ramos }\end{array}$ & & 182 \\
\hline \multirow[t]{2}{*}{181} & a. & $\begin{array}{l}\text { Nervação secundária } \\
\text { inconspícua, ramos } \\
\text { avermelhados, folhas elíptico- } \\
\text { lanceoladas, ápice agudo } \\
\end{array}$ & Maytenus sp & \\
\hline & b. & $\begin{array}{l}\text { Nervação secundária } \\
\text { promínula, ramos jovens } \\
\text { verdes, folhas lanceoladas, } \\
\text { ápice atenuado }\end{array}$ & Maytenus robusta & \\
\hline \multirow[t]{2}{*}{182} & a. & $\begin{array}{l}\text { Ramos jovens com nítidas } \\
\text { cicatrizes das estípulas } \\
\text { caducas, transversais ao } \\
\text { ramo }\end{array}$ & Lacistema hasslerianum & \\
\hline & b. & $\begin{array}{l}\text { Sem cicatrizes nítidas das } \\
\text { estípulas }\end{array}$ & & 183 \\
\hline
\end{tabular}

Quadro 2 - Chave dicotômica para as espécies arbustivo-arbóreas da E. E. dos Caetetus. 


\begin{tabular}{|c|c|c|c|c|}
\hline \multirow[t]{2}{*}{183} & a. & $\begin{array}{l}\text { Folhas espiraladas, aqui as } \\
\text { folhas estão dispostas em } \\
\text { geratris, observar insersão } \\
\text { dos peciolos nos ramos }\end{array}$ & Cariniana estrellensis & \\
\hline & b. & $\begin{array}{l}\text { Folhas dísticas, aqui parte das } \\
\text { folhas estão dispostas de um } \\
\text { lado do ramo e outra parte } \\
\text { esta disposta do lado oposto }\end{array}$ & & 184 \\
\hline \multirow[t]{2}{*}{184} & a. & Planta armada & $\begin{array}{l}\text { Xylosma } \\
\text { pseudosalzmanii }\end{array}$ & \\
\hline & b. & Planta inerme & $\begin{array}{l}\text { Casearia } \\
\text { gossypiosperma }\end{array}$ & \\
\hline \multirow[t]{2}{*}{185} & a. & $\begin{array}{l}\text { Folhas multinervadas na } \\
\text { base, cordiformes, com } \\
\text { pilosidade esbranquiçada na } \\
\text { face inferior e ramos jovens }\end{array}$ & & 186 \\
\hline & b. & $\begin{array}{l}\text { Folhas com uma única } \\
\text { nervura partindo da base }\end{array}$ & & 187 \\
\hline \multirow[t]{2}{*}{186} & a. & $\begin{array}{l}\text { Três nervuras partindo da } \\
\text { base do limbo, pelos } \\
\text { estrelados }\end{array}$ & Croton urucurana & \\
\hline & b. & $\begin{array}{l}\text { Mais de três nervuras partindo } \\
\text { da base do limbo, pêlos } \\
\text { simples }\end{array}$ & Bastardiopsis densiflora & \\
\hline \multirow[t]{2}{*}{187} & a. & Plantas armadas & & 188 \\
\hline & b. & Plantas inermes & & 189 \\
\hline \multirow[t]{2}{*}{188} & a. & $\begin{array}{l}\text { Espinhos solitários, retos, } 1 \text { a } \\
3 \mathrm{~cm} \text { de comprimento }\end{array}$ & Bouganvillea glabra & \\
\hline & b. & $\begin{array}{l}\text { Espinhos em pares, curvos, } \\
\text { na base das folhas, } 3 \text { a } 4 \mathrm{~cm} \\
\text { de comprimento }\end{array}$ & Seguieria floribunda & \\
\hline \multirow[t]{2}{*}{189} & a. & $\begin{array}{l}\text { Presença de pelos radiados } \\
\text { ou estrelados no limbo }\end{array}$ & & 190 \\
\hline & b. & $\begin{array}{l}\text { Folhas glabras ou com pelos } \\
\text { simples }\end{array}$ & & 199 \\
\hline \multirow[t]{2}{*}{190} & $a^{* \star}$ & Pelos radiados no limbo & & 191 \\
\hline & b. ** & Pelos estrelados no limbo & & 195 \\
\hline 191 & a. & $\begin{array}{l}\text { Pelos radiados pedicelados, } \\
\text { folhas discolores, oval- } \\
\text { lanceoladas, base } \\
\text { arredondada, ápice agudo }\end{array}$ & Croton floribundus & \\
\hline
\end{tabular}

Quadro 2 - Chave dicotômica para as espécies arbustivo-arbóreas da E. E. dos Caetetus. 


\begin{tabular}{|c|c|c|c|c|}
\hline & b. & $\begin{array}{l}\text { Pelos radiados séseis na face } \\
\text { inferior do limbo }\end{array}$ & & 192 \\
\hline \multirow[t]{2}{*}{192} & a. & Folhas concolores & & 193 \\
\hline & b. & Folhas discolores & & 194 \\
\hline \multirow[t]{2}{*}{193} & a. & $\begin{array}{l}\text { Folhas obovadas, } \\
\text { lanceoladas, base reflexa, } \\
\text { ápice de obtuso a } \\
\text { arredondado }\end{array}$ & Pera glabrata & \\
\hline & b. & $\begin{array}{l}\text { Folhas lanceoladas, base } \\
\text { cuneada, ápice agudo }\end{array}$ & Duguetia lanceolata & \\
\hline \multirow[t]{2}{*}{194} & a. & $\begin{array}{l}\text { Folhas arredondadas, face } \\
\text { inferior do limbo dourada, } \\
\text { base de cordada a } \\
\text { arredondada }\end{array}$ & $\begin{array}{l}\text { Hyeronima } \\
\text { alchorneoides }\end{array}$ & \\
\hline & b. & $\begin{array}{l}\text { Folhas lanceoladas, face } \\
\text { inferior do limbo prateada, } \\
\text { base aguda }\end{array}$ & Solanum argenteum & \\
\hline \multirow[t]{2}{*}{195} & a. & $\begin{array}{l}\text { Presença de estípulas } \\
\text { foliáceas, folhas discolores, } \\
\text { lanceoladas, pilosas em } \\
\text { ambas as faces }\end{array}$ & Solanum mauritianum & \\
\hline & b. & Sem estípulas foliáceas & & 196 \\
\hline \multirow[t]{2}{*}{196} & a. & $\begin{array}{l}\text { Pêlos estrelados associados } \\
\text { com pelos simples na face } \\
\text { inferior do limbo }\end{array}$ & & 197 \\
\hline & b. & $\begin{array}{l}\text { Pêlos estrelados dispersos } \\
\text { homogeneamente em toda a } \\
\text { face inferior do limbo }\end{array}$ & & 200 \\
\hline \multirow[t]{2}{*}{197} & a. & $\begin{array}{l}\text { Pilosidade acinzentada, ápice } \\
\text { atenuado }\end{array}$ & Styrax acuminatus & \\
\hline & b. & $\begin{array}{l}\text { Pilosidade castanha ou } \\
\text { ferruginea, ápice não } \\
\text { atenuado }\end{array}$ & & 198 \\
\hline \multirow[t]{2}{*}{198} & a. & $\begin{array}{l}\text { Pilosidade ferrugínea nas } \\
\text { gemas e ramos apicais e ao } \\
\text { longo das nervuras na face } \\
\text { inferior do limbo }\end{array}$ & Styrax pohlii & \\
\hline & b. & $\begin{array}{l}\text { Pilosidade ocrácea clara nas } \\
\text { gemas apicais e nervuras da } \\
\text { face inferior do limbo }\end{array}$ & Styrax camporum & \\
\hline
\end{tabular}

Quadro 2 - Chave dicotômica para as espécies arbustivo-arbóreas da E. E. dos Caetetus. 


\begin{tabular}{|c|c|c|c|c|}
\hline 199 & a. & $\begin{array}{l}\text { Folhas em pares sub-iguais, } \\
\text { glabras }\end{array}$ & Solanum pseudoquina & \\
\hline & b. & $\begin{array}{l}\text { Folhas nunca em pares sub- } \\
\text { iguais glabras ou pilosas }\end{array}$ & & 201 \\
\hline \multirow[t]{2}{*}{200} & a. & $\begin{array}{l}\text { Face superior do limbo } \\
\text { áspera, } 10 \text { a } 15 \mathrm{~cm} \text { de } \\
\text { comprimento, } 4 \text { a } 6 \mathrm{~cm} \text { de } \\
\text { largura, peciolo maior que } 1 \\
\text { cm de comprimento, } \\
\text { frequentemente assimétrica }\end{array}$ & Cordia trichotoma & \\
\hline & b. & $\begin{array}{l}\text { Face superior do limbo glabra } \\
\text { nas folhas adultas e nas } \\
\text { folhas jovens desprendendo- } \\
\text { se os pêlos facilmente; } \\
\text { comprimento do limbo de } 6 \text { a } \\
10 \mathrm{~cm} \text {, largura de } 2 \text { a } 4 \mathrm{~cm}, \\
\text { pecíolo menor que } 1 \mathrm{~cm} \text { de } \\
\text { comprimento }\end{array}$ & Cestrum calycinum & \\
\hline \multirow[t]{2}{*}{201} & a. & $\begin{array}{l}\text { Presença de duas glândulas } \\
\text { discóides dispostas } \\
\text { lateralmente à nervura } \\
\text { principal, na base do limbo }\end{array}$ & Prunus myrtifolia & \\
\hline & b. & $\begin{array}{l}\text { Ausência de glândulas no } \\
\text { limbo }\end{array}$ & & 202 \\
\hline \multirow[t]{2}{*}{202} & a. & Folhas nitidamente discolores & & 203 \\
\hline & b. & $\begin{array}{l}\text { Folhas concolores (material } \\
\text { jovem densamente piloso, } \\
\text { pilosidade ocrácea na face } \\
\text { inferior sugerindo } \\
\text { discoloridade em Nectandra } \\
\text { oppositifolia) }\end{array}$ & & 204 \\
\hline \multirow[t]{2}{*}{203} & a. & Pêlos esbranquiçados & Gochnatia polymorpha & \\
\hline & b. & Pêlos ferrugíneos & Nectandra oppositifolia & \\
\hline \multirow[t]{2}{*}{204} & a. & $\begin{array}{l}\text { Presença de pilosidade } \\
\text { ocrácea a ferrugínea nas } \\
\text { gemas e ao longo das } \\
\text { nervuras na face inferior do } \\
\text { limbo }\end{array}$ & & 205 \\
\hline & b. & $\begin{array}{l}\text { Folhas glabras ou com } \\
\text { pilosidade de outra coloração }\end{array}$ & & 213 \\
\hline
\end{tabular}

Quadro 2 - Chave dicotômica para as espécies arbustivo-arbóreas da E. E. dos Caetetus. 


\begin{tabular}{|c|c|c|c|c|}
\hline \multirow[t]{2}{*}{205} & a. & $\begin{array}{l}\text { Ramificação dicotômica, com } \\
\text { folha isolada inserida na } \\
\text { forquilha, folhas curto- } \\
\text { pecioladas, oval-lanceoladas, } \\
\text { base otusa a arredondada }\end{array}$ & Cordia sellowiana & \\
\hline & b. & $\begin{array}{l}\text { Ramificação não dicotômica e } \\
\text { ausência de folha na inserção } \\
\text { dos ramos }\end{array}$ & & 206 \\
\hline \multirow[t]{2}{*}{206} & a. & $\begin{array}{l}\text { Folhas obovado-espatuladas, } \\
\text { congestas }\end{array}$ & Terminalia brasiliensis & \\
\hline & b. & Folhas elípticas a lanceoladas & & 207 \\
\hline \multirow[t]{2}{*}{207} & a. & $\begin{array}{l}\text { Nervação peniparalelinérvea, } \\
\text { folhas com látex }\end{array}$ & $\begin{array}{l}\text { Chrysophyllum } \\
\text { marginatum }\end{array}$ & \\
\hline & b. & $\begin{array}{l}\text { Nervação não } \\
\text { peniparalelinérvea }\end{array}$ & & 208 \\
\hline \multirow[t]{2}{*}{208} & a. & $\begin{array}{l}\text { Ápice do limbo acuminado a } \\
\text { tênue acuminado }\end{array}$ & & 209 \\
\hline & b. & Ápice do limbo agudo & & 210 \\
\hline \multirow[t]{2}{*}{209} & a. & $\begin{array}{l}\text { Ramos jovens achatados } \\
\text { densamente ferrugíneos }\end{array}$ & Nectandra oppositifolia & \\
\hline & b. & $\begin{array}{l}\text { Ramos jovens cilíndricos, } \\
\text { ocráceo-pubescentes }\end{array}$ & Endlicheria paniculata & \\
\hline \multirow[t]{2}{*}{210} & a. & $\begin{array}{l}\text { Folhas densamente pilosas na } \\
\text { face inferior do limbo }\end{array}$ & & 211 \\
\hline & b. & $\begin{array}{l}\text { Folhas glabrescentes a } \\
\text { esparsamente pilosas na face } \\
\text { inferior do limbo }\end{array}$ & & 212 \\
\hline \multirow[t]{2}{*}{211} & a. & $\begin{array}{l}\text { Pecíolo de } 2 \text { a } 7 \mathrm{~mm} \text { de } \\
\text { comprimento e de } 2 \text { a } 3 \mathrm{~mm} \\
\text { de diâmetro }\end{array}$ & Ocotea velutina & \\
\hline & b. & $\begin{array}{l}\text { Peciolo com mais de } 8 \mathrm{~mm} \text { de } \\
\text { comprimento }\end{array}$ & Ocotea vellozziana & \\
\hline \multirow[t]{2}{*}{212} & a. & $\begin{array}{l}\text { Nervuras secundárias } \\
\text { ascendentes, planta sem látex }\end{array}$ & Nectandra lanceolata & \\
\hline & b. & $\begin{array}{l}\text { Nervação peninérvea, planta } \\
\text { com látex }\end{array}$ & Pouteria ramiflora & \\
\hline \multirow[t]{2}{*}{213} & a. & $\begin{array}{l}\text { Folhas alternas dísticas e/ou } \\
\text { divaricadas }\end{array}$ & & 214 \\
\hline & b. & $\begin{array}{l}\text { Folhas alternas sem estes } \\
\text { caracteres }\end{array}$ & & 217 \\
\hline 214 & a. & Folhas geminadas & Solanum pseudoquina & \\
\hline
\end{tabular}

Quadro 2 - Chave dicotômica para as espécies arbustivo-arbóreas da E. E. dos Caetetus. 


\begin{tabular}{|c|c|c|c|c|}
\hline & b. & Folhas não geminadas & & 215 \\
\hline \multirow[t]{2}{*}{215} & a. & $\begin{array}{l}\text { Folhas com } 4 \text { a } 8 \mathrm{~cm} \mathrm{de} \\
\text { comprimento, } 1 \text { a } 1,5 \mathrm{~cm} \text { de } \\
\text { largura, ápice rostrado } \\
\text { mucronado }\end{array}$ & Xylopia brasiliensis & \\
\hline & b. & Folhas sem estes caracteres & & 216 \\
\hline \multirow[t]{2}{*}{216} & a. & $\begin{array}{l}\text { Folhas lustrosas, pecíolo e } \\
\text { nervura principal amarelados }\end{array}$ & Annona cacans & \\
\hline & b. & $\begin{array}{l}\text { Folhas opacas, nervação de } \\
\text { cor não distinta do limbo }\end{array}$ & Rollinia exalbida & \\
\hline \multirow[t]{2}{*}{217} & a. & $\begin{array}{l}\text { Folhas e ramos pilosos, com } \\
\text { pelos simples abundantes em } \\
\text { ambas as faces do limbo }\end{array}$ & Vernonia diffusa & \\
\hline & b. & $\begin{array}{l}\text { Folhas glabras ou } \\
\text { glabrescentes }\end{array}$ & & 218 \\
\hline \multirow[t]{2}{*}{218} & a. & $\begin{array}{l}\text { Pecíolo longo, maior que } 1 / 5 \\
\text { do comprimento do limbo }\end{array}$ & & 219 \\
\hline & b. & $\begin{array}{l}\text { Pecíolo menor que } 1 / 5 \text { do } \\
\text { comprimento do limbo }\end{array}$ & & 225 \\
\hline \multirow[t]{2}{*}{219} & a. & $\begin{array}{l}\text { Folhas coriáceas, ovais a } \\
\text { elíptico lanceoladas, } 10 \text { a } 25 \\
\text { cm de comprimento, } 6 \text { a } 12 \\
\mathrm{~cm} \text { de largura, nervação } \\
\text { terciária reticulada conspícua }\end{array}$ & Talauma ovata & \\
\hline & b. & $\begin{array}{l}\text { Folhas membranáceas a } \\
\text { cartáceas, lanceoladas ou } \\
\text { elipticas }\end{array}$ & & 220 \\
\hline \multirow[t]{2}{*}{220} & a. & $\begin{array}{l}\text { Base arredondada com duas } \\
\text { glândulas inconspícuas, com } \\
\text { látex }\end{array}$ & Micrandra elata & \\
\hline & b. & $\begin{array}{l}\text { Base aguda, sem glândulas e } \\
\text { sem látex }\end{array}$ & & 221 \\
\hline \multirow[t]{2}{*}{221} & a. & $\begin{array}{l}\text { Comprimento da folha inferior } \\
\text { a } 8 \mathrm{~cm}\end{array}$ & Maprounea guianensis & \\
\hline & b. & $\begin{array}{l}\text { Comprimento da folha } \\
\text { superior a } 8 \mathrm{~cm}\end{array}$ & & 222 \\
\hline \multirow[t]{2}{*}{222} & a. & $\begin{array}{l}\text { Folhas cartáceas, oblongo- } \\
\text { lanceoladas }\end{array}$ & Persea pyrifolia & \\
\hline & b. & Folhas membranáceas & & 223 \\
\hline 223 & a. & Folhas oblongo-lanceoladas & Aspidosperma pavifolium & \\
\hline
\end{tabular}

Quadro 2 - Chave dicotômica para as espécies arbustivo-arbóreas da E. E. dos Caetetus. 


\begin{tabular}{|c|c|c|c|c|}
\hline & b. & Folhas oval-lanceoladas & & 224 \\
\hline \multirow[t]{2}{*}{224} & $a$. & $\begin{array}{l}\text { Pecíolo amarelado, longo, } \\
\text { com mais da metade do } \\
\text { comprimento do limbo }\end{array}$ & Phytolacca dioica & \\
\hline & b. & $\begin{array}{l}\text { Peciolo menor que a metade } \\
\text { do limbo, forte aroma de alho } \\
\text { nas folhas frescas }\end{array}$ & Gallesia integrifolia & \\
\hline \multirow[t]{2}{*}{225} & a. & $\begin{array}{l}\text { Estípulas filiformes } \\
\text { principalmente no ápice dos } \\
\text { ramos, articulação na ligação } \\
\text { do limbo com o pecíolo, tufos } \\
\text { de pêlos na inserção das } \\
\text { nervuras na face inferior do } \\
\text { limbo }\end{array}$ & Sloanea monosperma & \\
\hline & b. & Sem esses caracteres & & 226 \\
\hline \multirow[t]{2}{*}{226} & a. & Base reflexa & & 227 \\
\hline & b. & Base não reflexa & & 228 \\
\hline \multirow[t]{2}{*}{227} & $a$. & $\begin{array}{l}\text { Pilosidade serícea ocrácea na } \\
\text { face inferior do limbo, } \\
\text { nervação curvinérvea } \\
\text { ascendente, ápice cuspidado }\end{array}$ & Nectandra cuspidata & \\
\hline & b. & $\begin{array}{l}\text { Folhas glabras, nervação } \\
\text { peninérvea, ápice agudo a } \\
\text { arredondado }\end{array}$ & Ocotea sylvestris & \\
\hline \multirow[t]{2}{*}{228} & a. & $\begin{array}{l}\text { Presença de ócrea } \\
\text { inconspícua }\end{array}$ & Ruprechtia sp & \\
\hline & b. & Ausência de ócrea & & 229 \\
\hline \multirow[t]{2}{*}{229} & a. & $\begin{array}{l}\text { Presença de folha inserida na } \\
\text { bifurcação dos ramos }\end{array}$ & Cordia ecalyculata & \\
\hline & b. & $\begin{array}{l}\text { Ausência de folha na } \\
\text { bifurcação }\end{array}$ & & 230 \\
\hline \multirow[t]{2}{*}{230} & a. & $\begin{array}{l}\text { Base do limbo estreito-sub- } \\
\text { cordada, presença de } \\
\text { catáfilos na gema apical }\end{array}$ & Actinostemon concolor & \\
\hline & b. & Base aguda a obtusa & & 231 \\
\hline \multirow[t]{2}{*}{231} & a. & Folhas peniparalelinérveas & & 232 \\
\hline & b. & $\begin{array}{l}\text { Folhas não } \\
\text { peniparalelinérveas }\end{array}$ & & 235 \\
\hline 232 & a. & $\begin{array}{l}\text { Nervuras secundárias } \\
\text { ramificadas no meio }\end{array}$ & & 233 \\
\hline
\end{tabular}

Quadro 2 - Chave dicotômica para as espécies arbustivo-arbóreas da E. E. dos Caetetus. 


\begin{tabular}{|c|c|c|c|c|}
\hline & b. & $\begin{array}{l}\text { Nervuras secundárias não } \\
\text { ramificadas }\end{array}$ & & 234 \\
\hline \multirow[t]{2}{*}{233} & a. & $\begin{array}{l}\text { Folhas oblongo elípticas, de } \\
12 \text { a } 22 \mathrm{~cm} \text { de comprimento } \\
\text { por } 4 \text { a } 6 \mathrm{~cm} \text { de largura }\end{array}$ & $\begin{array}{l}\text { Aspidosperma } \\
\text { cylindrocarpon }\end{array}$ & \\
\hline & b. & $\begin{array}{l}\text { Folhas lanceoladas, de } 5 \text { a } 12 \\
\text { cm de comprimento por } 2 \text { a } 4 \\
\mathrm{~cm} \text { de largura }\end{array}$ & $\begin{array}{l}\text { Aspidosperma } \\
\text { polyneuron }\end{array}$ & \\
\hline \multirow[t]{2}{*}{234} & a. & Folha espatulada, com látex & $\begin{array}{l}\text { Chrysophyllum } \\
\text { gonocarpum }\end{array}$ & \\
\hline & b. & Folha elíptica, sem látex & Esenbeckia leiocarpa & \\
\hline \multirow[t]{2}{*}{235} & a. & $\begin{array}{l}\text { Folhas coriáceas; com menos } \\
\text { de } 5 \mathrm{~cm} \text { de largura }\end{array}$ & Ocotea diospyrifolia & \\
\hline & b. & $\begin{array}{l}\text { Folhas coriáceas cartáceas ou } \\
\text { membranáceas, com mais de } \\
5 \mathrm{~cm} \text { de largura }\end{array}$ & & 236 \\
\hline \multirow[t]{2}{*}{236} & $a$ & Folhas coriáceas & & 237 \\
\hline & b. & $\begin{array}{l}\text { Folhas cartáceas ou } \\
\text { membranáceas }\end{array}$ & & 238 \\
\hline \multirow[t]{2}{*}{237} & a. & $\begin{array}{l}\text { Folhas obovadas, pecíolo e } \\
\text { ramos amarelados }\end{array}$ & Citronela gorgonha & \\
\hline & b. & $\begin{array}{l}\text { Folhas elípticas, pecíolos e } \\
\text { ramos verdes }\end{array}$ & Citronela paniculata & \\
\hline \multirow[t]{2}{*}{238} & a. & Folhas membranáceas & & 239 \\
\hline & b. & Folhas cartáceas & & 241 \\
\hline \multirow[t]{2}{*}{239} & a. & Pecíolo piloso & $\begin{array}{l}\text { Actinostemon } \\
\text { concepciones }\end{array}$ & \\
\hline & b. & Pecíolo glabro & & 240 \\
\hline \multirow[t]{2}{*}{240} & a. & $\begin{array}{l}\text { Face superior do limbo opaca, } \\
\text { casca lisa, descamante em } \\
\text { placas, clara }\end{array}$ & Savia dyctiocarpa & \\
\hline & b. & $\begin{array}{l}\text { Face superior do limbo } \\
\text { brilhante, casca rugosa, } \\
\text { escura }\end{array}$ & Margaritaria nobilis & \\
\hline \multirow[t]{2}{*}{241} & a. & Limbo decorrente no pecíolo & Agonandra engleri & \\
\hline & b. & $\begin{array}{l}\text { Limbo não decorrente no } \\
\text { pecíolo }\end{array}$ & & 242 \\
\hline \multirow[t]{2}{*}{242} & a. & $\begin{array}{l}\text { Tufos de pêlos nas axilas das } \\
\text { nervuras secundárias }\end{array}$ & Ocotea corymbosa & \\
\hline & b. & $\begin{array}{l}\text { Folhas completamente } \\
\text { glabras }\end{array}$ & & 243 \\
\hline
\end{tabular}

Quadro 2 - Chave dicotômica para as espécies arbustivo-arbóreas da E. E. dos Caetetus. 


\begin{tabular}{|l|l|l|l|}
\hline 243 & a. & $\begin{array}{l}\text { Ramificação congesta, folhas } \\
\text { com } 7 \text { a } 13 \mathrm{~cm} \text { de } \\
\text { comprimento por } 2,5 \text { a 3,5 de } \\
\text { largura, ápice rostrado }\end{array}$ & Ocotea indecora \\
\hline b. & $\begin{array}{l}\text { Ramificação laxa, folhas com } \\
8 \text { a } 12 \mathrm{~cm} \text { de comprimento por } \\
1,5 \text { a } 2,5 \mathrm{~cm} \text { de largura, ápice } \\
\text { acuminado }\end{array}$ & $\begin{array}{l}\text { Nectandra } \\
\text { megapotamica }\end{array}$ &
\end{tabular}

Quadro 2 - Chave dicotômica para as espécies arbustivo-arbóreas da E. E. dos Caetetus.

\subsection{Observações e recomendações para uso da chave}

$a^{*} / b^{*}$ Tabernaemontana hystrix pode apresentar folhas verticiladas nos ramos jovens. Porém, usualmente, apresenta folhas opostas.

a. * pêlos radiados: ramificações inseridas em raio, em um mesmo plano

b. ** pêlos estrelados: ramificaçōes inseridas em diversos planos

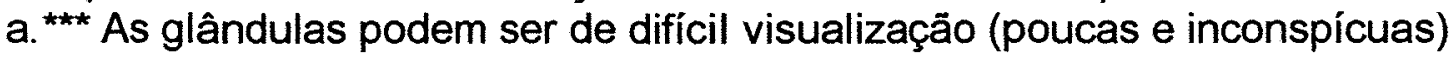

Equipamento mínimo: régua, lupa $10 \mathrm{X}$

Não utilizar material de plantas jovens 
3.5 Fitossociologia de dois trechos de floresta da Estação Ecológica dos Caetetus - Gália - SP

\subsubsection{Curvas do coletor}

As curvas do coletor representam o incremento de novas espécies à medida que foram acrescentadas novas unidades amostrais, para os dois trechos de floresta na Estação Ecológica dos Caetetus, este incremento foi feito na seqüêcia real das parcelas, para que fossem evidenciadas possíveis mudanças na comunidade. As curvas apresentaram forte tendência para estabilização, sendo que na área A verifica-se um maior incremento de espécies até a $33^{a}$ parcela. A partir daí, o incremento é semelhante nas duas áreas (Figura 3).

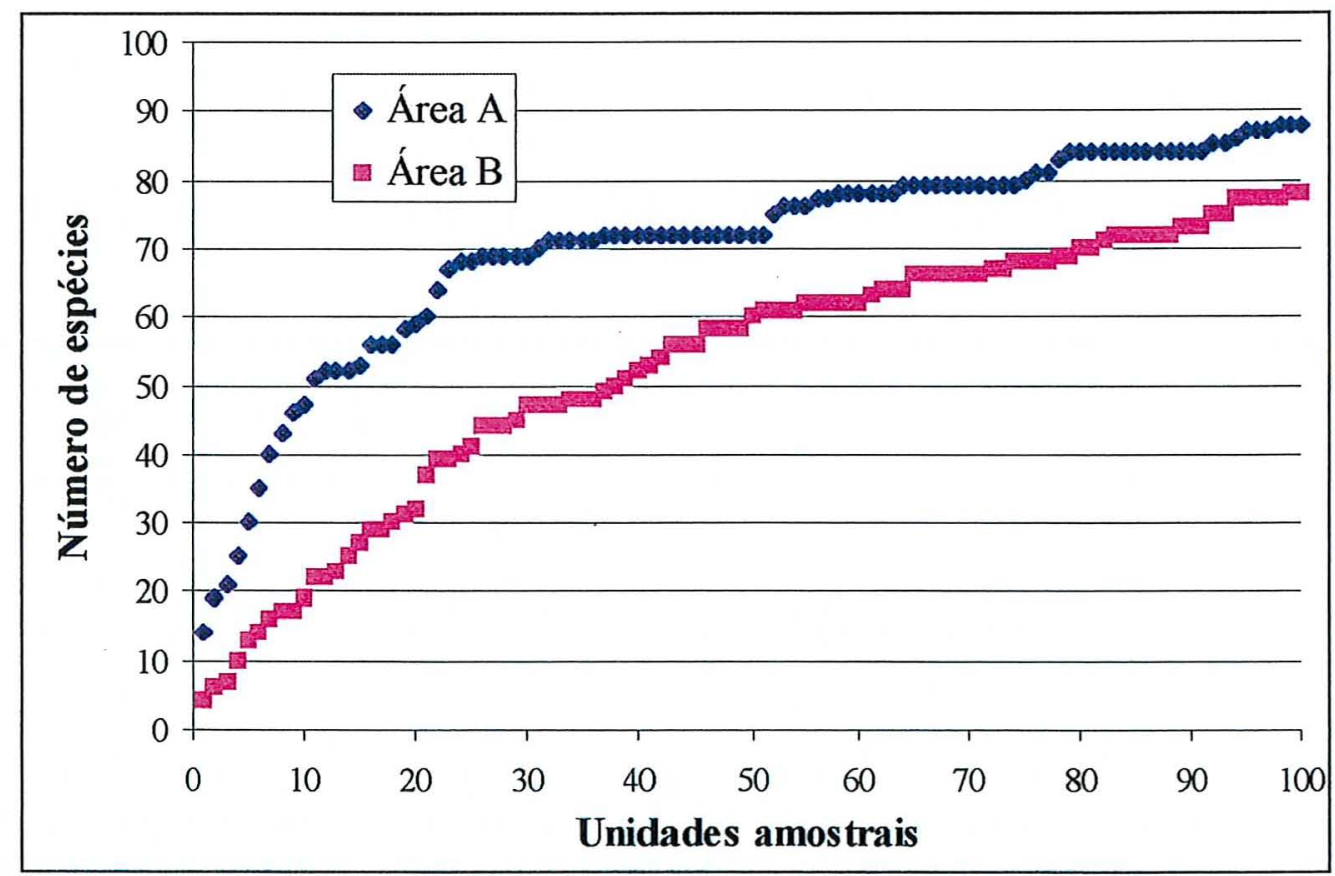

Figura 3 - Representação gráfica da curva do coletor para as áreas (A) e (B), estas mostram o incremento de novas espécies em função do aumento das unidades amostrais. 


\subsubsection{Distribuição diamétrica da comunidade}

Os gráficos apresentados para distribuição diamétrica das comunidades arbustivo-arbóreas dos trrechos $A$ e $B$ seguem o modelo esperado de $(\mathrm{J})$ invertido para ambas as áreas e mostram que a primeira (área $\mathrm{A}$ ) apresenta maior número de indivíduos nas três primeiras classes, até 10, 20 e $30 \mathrm{~cm}$ de diâmetro; invertendo tal comportamento nas classes seqüentes de 40 até $150 \mathrm{~cm}$ (Figura 4).

A área $\mathrm{A}$ tem como densidade 1282 ind./ha e área basal total de $23,77 \mathrm{~m}^{2} /$ há, ao passo que a área $B$ apresenta 1111 ind./ha e área basal total de 29,33 $\mathrm{m}^{2} /$ há. Apesar de A possuir maior densidade, os indivíduos das classes diamétricas $40-150 \mathrm{~cm}$ de $B$ conferem a esta maior área basal. Estes dados demonstram que solos mais férteis levam à menor densidade com árvores de grande porte $e$, portanto, maior área basal. Ainda devemos considerar um possível extrativismo seletivo, dado o fácil acesso da (área A), este teria um efeito semelhante, ou seja, aumento de indivíduos nas classes diamétricas menores e diminuição da área basal total. 


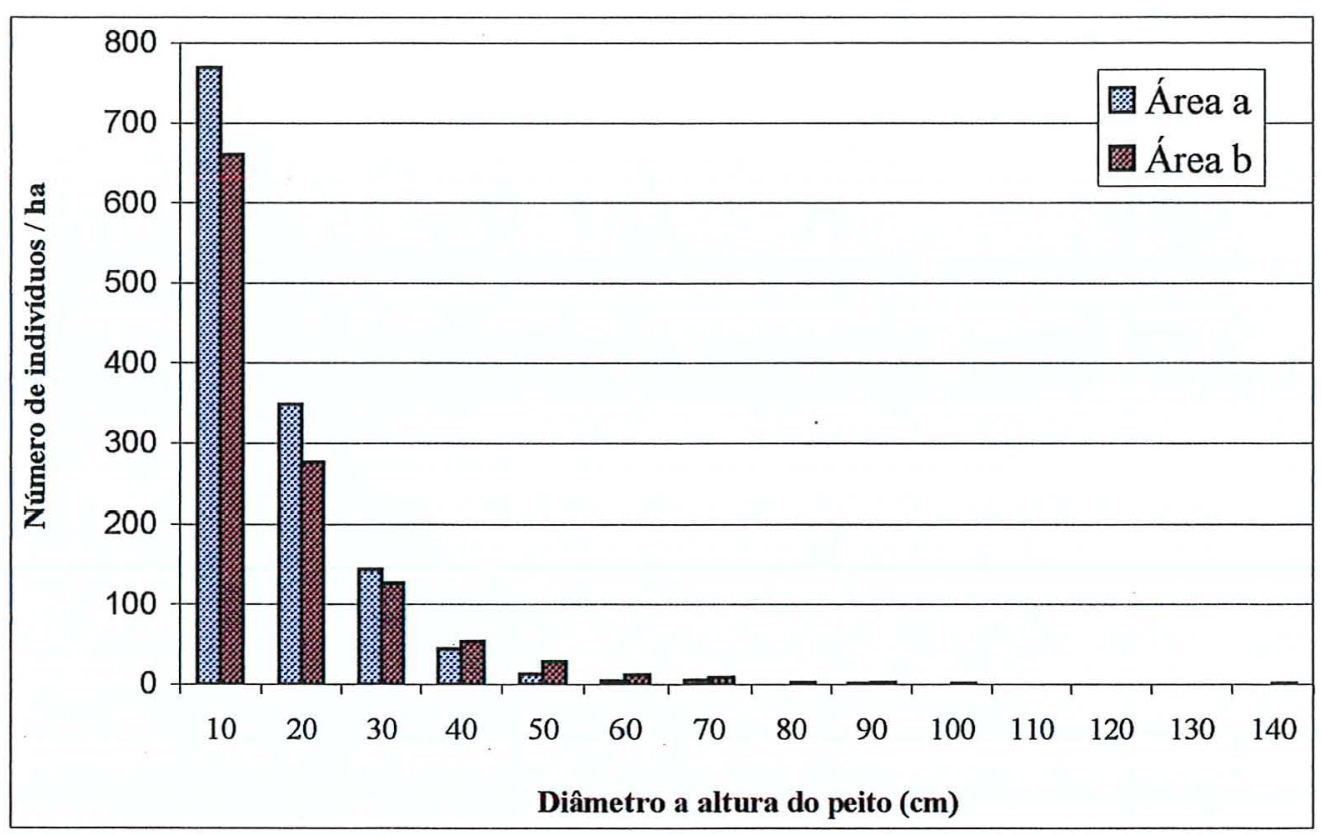

Figura 4 - Distribuição diamétrica das comunidades das áreas $\mathrm{A}$ e $\mathrm{B}$, representando o número de indivíduos por classe de diâmetro por hectare.

\subsubsection{Parâmetros fitossociológicos}

A Tabela 2 traz o resumo dos parâmetros fitossociológicos para as áreas $\mathrm{A}$ e $\mathrm{B}$. Os parâmetros fitossociológicos para as espécies estão apresentados na Tabela 3 para a área A e na Tabela 4 para a área $B$. 
Tabela 2. Parâmetros fitossociológicos para as áreas A e B.

\begin{tabular}{lcc}
\hline \multicolumn{1}{c}{ Parâmetros } & Área A & Área B \\
\hline No. de espécies(S) & 87 & 77 \\
Índice Shannon(H') & 3,17 & 2,42 \\
Equabilidade $\left(\mathrm{J}=\mathrm{H}^{\prime} / \mathrm{ln}(\mathrm{S})\right)$ & 0,711 & 0,56 \\
No. de familias & 33 & 34 \\
Densidade total/ha & 1282,00 & 1111,00 \\
Área basal total $\left(\mathrm{m}^{2} \mathrm{ha}^{-1}\right)$ & 23,77 & 29,33 \\
Diâmetro máximo & 80,50 & 133,50 \\
Diâmetro mínimo & 5,00 & 5,00 \\
Diâmetro médio & 12,29 & 13,67 \\
Altura máxima & 35,00 & 33,00 \\
Altura mínima & 1,70 & 1,30 \\
Altura média & 10,42 & 9,69 \\
Indivíduos mortos (\%) & 3,7 & 4,9 \\
\hline
\end{tabular}


Tabela 3. Parâmetros fitossociológicos para as espécies amostradas em Floresta Estacional Semidecidual em Gália, SP. (área A). Dens. Abs. Densidade Absoluta, Dens.Rel.- Densidade Relativa(\%), Dom.Rel.- Dominância Relativa(\%), Freq.Rel.- Freqüência Relativa(\%), IVI - Índice de Valor de Importância e IVC - Índice de Valor de Cobertura.

\begin{tabular}{|c|c|c|c|c|c|c|}
\hline Espécie & $\begin{array}{l}\text { Dens. } \\
\text { Abs. }\end{array}$ & $\begin{array}{l}\text { Dens. } \\
\text { Rel. }\end{array}$ & $\begin{array}{l}\text { Dom. } \\
\text { Rel. }\end{array}$ & $\begin{array}{l}\text { Freq. } \\
\text { Rel. }\end{array}$ & IVI & IVC \\
\hline Savia dyctiocarpa & 371,00 & 28,94 & 25,02 & 9,99 & 63,94 & 53,96 \\
\hline Actinostemon concepcionis & 170,00 & 13,26 & 1,91 & 9,85 & 25,02 & 15,17 \\
\hline Astronium graveolens. & 80,00 & 6,24 & 4,22 & 6,92 & 17,39 & 10,46 \\
\hline Piptadenia gonoacantha & 30,00 & 2,34 & 8,20 & 3,20 & 13,73 & 10,54 \\
\hline Croton floribundus & 35,00 & 2,73 & 6,66 & 3,99 & 13,39 & 9,40 \\
\hline Aspidosperma polyneuron & 15,00 & 1,17 & 7,68 & 1,86 & 10,71 & 8,85 \\
\hline Inga striata & 30,00 & 2,34 & 2,84 & 3,73 & 8,91 & 5,18 \\
\hline Ocotea indecora & 24,00 & 1,87 & 3,02 & 2,93 & 7,82 & 4,89 \\
\hline Myrcia fallax & 28,00 & 2,18 & 1,44 & 3,33 & 6,95 & 3,62 \\
\hline Margaritaria nobilis & 16,00 & 1,25 & 3,42 & 1,86 & 6,53 & 4,67 \\
\hline xyllum pohlianum & 26,00 & 2,03 & 0,99 & 3,06 & 6,08 & 3,02 \\
\hline Zanthoxyllum juniperinun & 28,00 & 2,18 & 1,15 & 2,26 & 5,60 & 3,34 \\
\hline Casearia gossypiosperma & 22,00 & 1,72 & 0,99 & 2,26 & 4,97 & 2,71 \\
\hline Pilocarpus pauciflorus & 32,00 & 2,50 & 0,55 & 1,73 & 4,78 & 3,05 \\
\hline a courbaril & 8,00 & 0,62 & 3,18 & 0,93 & 4,74 & 3,80 \\
\hline Alchornea triplinervia & 11,00 & 0,86 & 2,27 & 1,33 & 4,46 & 3,12 \\
\hline ea guianensi & 18,00 & 1,40 & 1,11 & 1,86 & 4,37 & 2,51 \\
\hline Trichilia pallida & 20,00 & 1,56 & 0,54 & 2,26 & 4,36 & 2,10 \\
\hline Calyptranthes clusiaefolia & 19,00 & 1,48 & 0,58 & 1,86 & 3,93 & 2,06 \\
\hline Mabea fistulifera & 11,00 & 0,86 & 2,09 & 0,80 & 3,74 & 2,94 \\
\hline rasiliensis & 16,00 & 1,25 & 0,57 & 1,60 & 3,41 & 1,81 \\
\hline Didymopanax $s p$ & 5,00 & 0,39 & 2,03 & 0,67 & 3,09 & 2,42 \\
\hline Syagrus rommanzoffiana & 9,00 & 0,70 & 1,07 & 1,20 & 2,97 & 1,77 \\
\hline Didymopanax morototoni & 8,00 & 0,62 & 1,23 & 1,07 & 2,92 & 1,85 \\
\hline Aparisthmium cordatum & 17,00 & 1,33 & 0,38 & 1,07 & 2,77 & 1,71 \\
\hline Zeyhera tuberculosa & 11,00 & 0,86 & 0,53 & 1,33 & 2,72 & 1,39 \\
\hline Colubrina glandulosa & 7,00 & 0,55 & 1,20 & 0,93 & 2,68 & 1,75 \\
\hline ioraviana & 11,00 & 0,86 & 0,43 & 1,33 & 2,62 & 1,29 \\
\hline orymbosa & 9,00 & 0,70 & 0,55 & 1,20 & 2,46 & 1,26 \\
\hline Sloanea monosperma & 9,00 & 0,70 & 0,40 & 1,20 & 2,30 & 1,11 \\
\hline Lonchocarpus cultratus & 7,00 & 0,55 & 0,76 & 0,93 & 2,24 & 1,31 \\
\hline Cordia ecalyculata & 10,00 & 0,78 & 0,36 & 1,07 & 2,20 & 1,14 \\
\hline ra oppositifolia & 5,00 & 0,39 & 1,00 & 0,67 & 2,05 & 1,39 \\
\hline rruginea & 3,00 & 0,23 & 1,41 & 0,40 & 2,04 & 1,64 \\
\hline Casearia obliqua & 6,00 & 0,47 & 0,83 & 0,67 & 1,96 & 1,29 \\
\hline
\end{tabular}


Tabela 3. Parâmetros fitossociológicos para as espécies amostradas em Floresta Estacional Semidecidual em Gália, SP. (área A). Dens. Abs. Densidade Absoluta, Dens.Rel.- Densidade Relativa(\%), Dom.Rel.- Dominância Relativa(\%), Freq.Rel.- Freqüência Relativa(\%), IVI - Índice de Valor de Importância e IVC - Índice de Valor de Cobertura.

\begin{tabular}{|c|c|c|c|c|c|c|}
\hline Espécie & $\begin{array}{l}\text { Dens. } \\
\text { Abs. }\end{array}$ & $\begin{array}{c}\text { Dens. } \\
\text { Rel. }\end{array}$ & $\begin{array}{l}\text { Dom. } \\
\text { Rel. }\end{array}$ & $\begin{array}{l}\text { Freq. } \\
\text { Rel. }\end{array}$ & IVI & IVC \\
\hline Cariniana estrellensis & 7,00 & 0,55 & 0,43 & 0,93 & 1,91 & 0,98 \\
\hline Machaerium stipitatum & 7,00 & 0,55 & 0,63 & 0,67 & 1,84 & 1,18 \\
\hline Esenbeckia grandiflora & 9,00 & 0,70 & 0,20 & 0,93 & 1,83 & 0,90 \\
\hline Duguetia lanceolata & 7,00 & 0,55 & 0,48 & 0,80 & 1,82 & 1,02 \\
\hline Balfourodendron riedelianum & 7,00 & 0,55 & 0,42 & 0,80 & 1,76 & 0,97 \\
\hline Pisonia ambígua & 6,00 & 0,47 & 0,40 & 0,80 & 1,66 & 0,87 \\
\hline Cabralea canjerana & 5,00 & 0,39 & 0,56 & 0,67 & 1,62 & 0,95 \\
\hline Agonandra englenii & 7,00 & 0,55 & 0,30 & 0,67 & 1,51 & 0,85 \\
\hline Piptocarpha sellowii & 5,00 & 0,39 & 0,86 & 0,27 & 1,51 & 1,25 \\
\hline Rapanea umbellata & 5,00 & 0,39 & 0,39 & 0,67 & 1,45 & 0,78 \\
\hline Annona cacans & 4,00 & 0,31 & 0,52 & 0,53 & 1,36 & 0,83 \\
\hline Swetia fruticosa & 7,00 & 0,55 & 0,13 & 0,67 & 1,34 & 0,67 \\
\hline Alchornea glandulosa & 3,00 & 0,23 & 0,82 & 0,27 & 1,32 & 1,06 \\
\hline Eugenia blastantha & 5,00 & 0,39 & 0,12 & 0,67 & 1,18 & 0,51 \\
\hline Ormosia arbórea & 4,00 & 0,31 & 0,29 & 0,53 & 1,14 & 0,60 \\
\hline Mollinedia widgrenii & 4,00 & 0,31 & 0,08 & 0,53 & 0,93 & 0,40 \\
\hline Calliandra foliolosa & 4,00 & 0,31 & 0,06 & 0,53 & 0,91 & 0,37 \\
\hline Chrysophyllum gonocarpum & 3,00 & 0,23 & 0,27 & 0,40 & 0,90 & 0,50 \\
\hline Cordia sellowiana & 3,00 & 0,23 & 0,33 & 0,27 & 0,84 & 0,57 \\
\hline Pouteria ramiflora & 1,00 & 0,08 & 0,53 & 0,13 & 0,74 & 0,61 \\
\hline Prunus myrtifolia & 3,00 & 0,23 & 0,10 & 0,40 & 0,73 & 0,33 \\
\hline Chomelia pohliana & 3,00 & 0,23 & 0,08 & 0,40 & 0,72 & 0,32 \\
\hline Holocalyx balansae & 3,00 & 0,23 & 0,04 & 0,40 & 0,68 & 0,28 \\
\hline Amaioua intermdia & 3,00 & 0,23 & 0,04 & 0,40 & 0,67 & 0,27 \\
\hline Roupala brasiliensis & 3,00 & 0,23 & 0,04 & 0,40 & 0,67 & 0,27 \\
\hline Myrciaria ciliolata & 3,00 & 0,23 & 0,03 & 0,40 & 0,67 & 0,27 \\
\hline Styrax acuminatus & 2,00 & 0,16 & 0,11 & 0,27 & 0,53 & 0,27 \\
\hline Ficus insipida & 2,00 & 0,16 & 0,10 & 0,27 & 0,52 & 0,26 \\
\hline Nectandra megapotamica & 2,00 & 0,16 & 0,09 & 0,27 & 0,51 & 0,24 \\
\hline Machaerium brasiliensis & 2,00 & 0,16 & 0,05 & 0,27 & 0,47 & 0,21 \\
\hline Rollinia exalbida & 2,00 & 0,16 & 0,04 & 0,27 & 0,46 & 0,19 \\
\hline Centrolobium tomentos & 2,00 & 0,16 & 0,04 & 0,27 & 0,46 & 0,19 \\
\hline Esenbeckia leiocarpa & 2,00 & 0,16 & 0,03 & 0,27 & 0,46 & 0,19 \\
\hline Actinostemon concolor & 2,00 & 0,16 & 0,02 & 0,27 & 0,44 & 0,17 \\
\hline
\end{tabular}


Tabela 3. Parâmetros fitossociológicos para as espécies amostradas em Floresta Estacional Semidecidual em Gália, SP. (área A). Dens. Abs. Densidade Absoluta, Dens.Rel.- Densidade Relativa(\%), Dom.Rel.- Dominância Relativa(\%), Freq.Rel.- Freqüência Relativa(\%), IVI - Índice de Valor de Importância e IVC - Índice de Valor de Cobertura.

\begin{tabular}{lcccccc}
\hline \multicolumn{1}{c}{ Espécie } & $\begin{array}{c}\text { Dens. } \\
\text { Abs. }\end{array}$ & $\begin{array}{c}\text { Dens. } \\
\text { Rel. }\end{array}$ & $\begin{array}{c}\text { Dom. } \\
\text { Rel. }\end{array}$ & $\begin{array}{c}\text { Freq. } \\
\text { Rel. }\end{array}$ & IVI & IVC \\
\hline Chorisia speciosa & 1,00 & 0,08 & 0,19 & 0,13 & 0,40 & 0,27 \\
Copaifera langsdorffii & 1,00 & 0,08 & 0,13 & 0,13 & 0,34 & 0,21 \\
Albizia hasslerii & 1,00 & 0,08 & 0,11 & 0,13 & 0,32 & 0,19 \\
Tapirira guianensis & 1,00 & 0,08 & 0,06 & 0,13 & 0,27 & 0,13 \\
Trichilia catigua. & 1,00 & 0,08 & 0,06 & 0,13 & 0,27 & 0,13 \\
Coutarea hexandra & 1,00 & 0,08 & 0,03 & 0,13 & 0,24 & 0,11 \\
Jacaranda micrantha & 1,00 & 0,08 & 0,03 & 0,13 & 0,24 & 0,10 \\
Trichilia casaretti & 1,00 & 0,08 & 0,03 & 0,13 & 0,24 & 0,10 \\
Prockia crucis & 1,00 & 0,08 & 0,02 & 0,13 & 0,23 & 0,10 \\
Rhamnidium elaeocarpum & 1,00 & 0,08 & 0,01 & 0,13 & 0,22 & 0,09 \\
Ficus sp & 1,00 & 0,08 & 0,01 & 0,13 & 0,22 & 0,09 \\
Pera glabrata & 1,00 & 0,08 & 0,01 & 0,13 & 0,22 & 0,09 \\
Ocotea dyospirifolia & 1,00 & 0,08 & 0,01 & 0,13 & 0,22 & 0,09 \\
Myrcia bella & 1,00 & 0,08 & 0,01 & 0,13 & 0,22 & 0,09 \\
Platyciamus regnellii & 1,00 & 0,08 & 0,01 & 0,13 & 0,22 & 0,09 \\
Neomytranthes glomerata & 1,00 & 0,08 & 0,01 & 0,13 & 0,22 & 0,09 \\
Cupania zanthoxyloides & 1,00 & 0,08 & 0,01 & 0,13 & 0,22 & 0,09 \\
Urera baccifera & 1,00 & 0,08 & 0,01 & 0,13 & 0,22 & 0,09 \\
\hline
\end{tabular}


Tabela 4. Parâmetros fitossociológicos para as espécies amostradas em Floresta Estacional Semidecidual em Gália, SP. (área B). Dens. Abs. Densidade Absoluta, Dens.Rel.- Densidade Relativa(\%), Dom.Rel.- Dominância Relativa(\%), Freq.Rel.- Freqüência Relativa(\%), IVI - Índice de Valor de Importância e IVC - Índice de Valor de Cobertura.

\begin{tabular}{|c|c|c|c|c|c|c|}
\hline Espécie & $\begin{array}{l}\text { Dens. } \\
\text { Abs. }\end{array}$ & $\begin{array}{c}\text { Dens. } \\
\text { Rel. }\end{array}$ & $\begin{array}{l}\text { Dom. } \\
\text { Rel. }\end{array}$ & $\begin{array}{c}\text { Freq. } \\
\text { Rel. }\end{array}$ & IVI & IVC \\
\hline Metrodorea nigra & 468,00 & 42,12 & 9,57 & 17,66 & 69,36 & 51,70 \\
\hline Savia dyctiocarpa & 215,00 & 19,35 & 25,86 & 11,89 & 57,10 & 45,21 \\
\hline $\begin{array}{l}\text { Ocotea indecora. } \\
\text { Aspidosperma }\end{array}$ & 52,00 & 4,68 & 9,23 & 7,75 & 21,66 & 13,91 \\
\hline polyneuron & 41,00 & 3,69 & 8,19 & 5,77 & 17,65 & 11,88 \\
\hline $\begin{array}{l}\text { Trichilia catigua } \\
\text { Chrysophyllum }\end{array}$ & 45,00 & 4,05 & 1,10 & 6,85 & 12,00 & 5,15 \\
\hline gonocarpum & 21,00 & 1,89 & 2,01 & 3,60 & 7,51 & 3,90 \\
\hline Syagrus rommanzoffiana & 17,00 & 1,53 & 2,22 & 2,88 & 6,64 & 3,75 \\
\hline Croton floribundus & 14,00 & 1,26 & 2,37 & 1,80 & 5,43 & 3,63 \\
\hline Gallesia integrifolia & 2,00 & 0,18 & 4,80 & 0,36 & 5,34 & 4,98 \\
\hline Cabralea canjerana & 9,00 & 0,81 & 2,55 & 1,62 & 4,98 & 3,36 \\
\hline Astronium graveolens & 11,00 & 0,99 & 1,93 & 1,98 & 4,90 & 2,92 \\
\hline Alchornea glandulosa & 8,00 & 0,72 & 2,85 & 1,26 & 4,83 & 3,57 \\
\hline Trichilia pallida & 16,00 & 1,44 & 0,42 & 2,88 & 4,74 & 1,86 \\
\hline Parapiptadenia rígida & 7,00 & 0,63 & 2,80 & 1,26 & 4,69 & 3,43 \\
\hline Cedrela fissilis & 3,00 & 0,27 & 3,71 & 0,54 & 4,52 & 3,98 \\
\hline Trichilia claussenii & 14,00 & 1,26 & 0,79 & 2,34 & 4,39 & 2,05 \\
\hline Sloanea monosperma & 9,00 & 0,81 & 0,98 & 1,62 & 3,41 & 1,79 \\
\hline Zanthoxyllum juniperinun & 12,00 & 1,08 & 0,34 & 1,98 & 3,40 & 1,42 \\
\hline Mollinedia widgrenii & 10,00 & 0,90 & 0,68 & 1,80 & 3,38 & 1,58 \\
\hline Patagonula americana & 7,00 & 0,63 & 1,44 & 1,26 & 3,33 & 2,07 \\
\hline Cariniana estrellensis & 1,00 & 0,09 & 2,47 & 0,18 & 2,74 & 2,56 \\
\hline Syagrus oleracea & 8,00 & 0,72 & 0,66 & 1,26 & 2,64 & 1,38 \\
\hline $\begin{array}{l}\text { Acacia polyphylla } \\
\text { Balfourodendron }\end{array}$ & 4,00 & 0,36 & 1,25 & 0,72 & 2,33 & 1,61 \\
\hline riedelianum & 6,00 & 0,54 & 0,65 & 1,08 & 2,27 & 1,19 \\
\hline Eugenia moraviana & 7,00 & 0,63 & 0,24 & 1,26 & 2,13 & 0,87 \\
\hline $\begin{array}{l}\text { Actinostemon concolor } \\
\text { Centrolobium }\end{array}$ & 7,00 & 0,63 & 0,09 & 1,26 & 1,98 & 0,72 \\
\hline tomentosum & 5,00 & 0,45 & 0,58 & 0,90 & 1,93 & 1,03 \\
\hline Holocalyx balansae & 4,00 & 0,36 & 0,65 & 0,72 & 1,73 & 1,01 \\
\hline Peltophorum dubium & 1,00 & 0,09 & 1,35 & 0,18 & 1,62 & 1,44 \\
\hline Jacaratia spinosa & 4,00 & 0,36 & 0,44 & 0,72 & 1,52 & 0,80 \\
\hline Guarea kunthiana & 4,00 & 0,36 & 0,28 & 0,72 & 1,36 & 0,64 \\
\hline
\end{tabular}


Tabela 4. Parâmetros fitossociológicos para as espécies amostradas em Floresta Estacional Semidecidual em Gália, SP. (área B). Dens. Abs. Densidade Absoluta, Dens.Rel.-Densidade Relativa(\%), Dom.Rel.- Dominância Relativa(\%), Freq.Rel.- Freqüência Relativa(\%), IVI - Índice de Valor de Importância e IVC - Índice de Valor de Cobertura.

\begin{tabular}{|c|c|c|c|c|c|c|}
\hline Espécie & $\begin{array}{l}\text { Dens. } \\
\text { Abs. }\end{array}$ & $\begin{array}{l}\text { Dens. } \\
\text { Rel. }\end{array}$ & $\begin{array}{l}\text { Dom. } \\
\text { Rel. }\end{array}$ & $\begin{array}{l}\text { Freq. } \\
\text { Rel. }\end{array}$ & IVI & IVC \\
\hline \multicolumn{7}{|l|}{ Rhamnidium } \\
\hline elaeocarpum. & 3,00 & 0,27 & 0,48 & 0,54 & 1,29 & 0,75 \\
\hline Pilocarpus pauciflorus & 4,00 & 0,36 & 0,20 & 0,72 & 1,28 & 0,56 \\
\hline \multicolumn{7}{|l|}{ Campomanesia } \\
\hline xanthocarpa & 4,00 & 0,36 & 0,19 & 0,72 & 1,27 & 0,55 \\
\hline $\begin{array}{l}\text { Eugenia blastantha } \\
\text { Actinostemon }\end{array}$ & 4,00 & 0,36 & 0,15 & 0,72 & 1,23 & 0,51 \\
\hline concepcionis & 4,00 & 0,36 & 0,06 & 0,72 & 1,14 & 0,42 \\
\hline Machaerium stipitatum & 3,00 & 0,27 & 0,30 & 0,54 & 1,11 & 0,57 \\
\hline Campomanesia rhombea & 3,00 & 0,27 & 0,26 & 0,54 & 1,07 & 0,53 \\
\hline Machaerium nictitans & 2,00 & 0,18 & 0,48 & 0,36 & 1,02 & 0,66 \\
\hline Cordia ecalyculata & 4,00 & 0,36 & 0,12 & 0,54 & 1,02 & 0,48 \\
\hline Chorisia speciosa & 1,00 & 0,09 & 0,70 & 0,18 & 0,97 & 0,79 \\
\hline Machaerium brasiliensis & 2,00 & 0,18 & 0,40 & 0,36 & 0,94 & 0,58 \\
\hline Myrciaria sp & 3,00 & 0,27 & 0,09 & 0,54 & 0,90 & 0,36 \\
\hline Cassia ferruginea & 1,00 & 0,09 & 0,59 & 0,18 & 0,86 & 0,68 \\
\hline Lonchocarpus cultratus & 1,00 & 0,09 & 0,59 & 0,18 & 0,86 & 0,68 \\
\hline Piptadenia gonoacantha & 1,00 & 0,09 & 0,56 & 0,18 & 0,83 & 0,65 \\
\hline Diatenopteryx sorbifolia & 1,00 & 0,09 & 0,50 & 0,18 & 0,77 & 0,59 \\
\hline Zeyhera tuberculosa & 2,00 & 0,18 & 0,19 & 0,36 & 0,73 & 0,37 \\
\hline Inga striata & 2,00 & 0,18 & 0,14 & 0,36 & 0,68 & 0,32 \\
\hline Solanum argenteum & 3,00 & 0,27 & 0,04 & 0,36 & 0,67 & 0,31 \\
\hline \multicolumn{7}{|l|}{ Nectandra } \\
\hline megapotamica & 2,00 & 0,18 & 0,06 & 0,36 & 0,60 & 0,24 \\
\hline Agonandra englerii & 2,00 & 0,18 & 0,05 & 0,36 & 0,59 & 0,23 \\
\hline Citronela paniculata & 2,00 & 0,18 & 0,04 & 0,36 & 0,58 & 0,22 \\
\hline Cupania zanthoxyloides & 2,00 & 0,18 & 0,01 & 0,36 & 0,56 & 0,19 \\
\hline Sciadodendron exce/sum & 1,00 & 0,09 & 0,26 & 0,18 & 0,53 & 0,35 \\
\hline Pisonia ambigua & 1,00 & 0,09 & 0,24 & 0,18 & 0,51 & 0,33 \\
\hline Albizia polycephala & 1,00 & 0,09 & 0,23 & 0,18 & 0,50 & 0,32 \\
\hline \multicolumn{7}{|l|}{ Enterolobium } \\
\hline contortissiliquum & 1,00 & 0,09 & 0,19 & 0,18 & 0,46 & 0,28 \\
\hline Bunchosia pallescens & 1,00 & 0,09 & 0,09 & 0,18 & 0,36 & 0,18 \\
\hline Solanum pseudoquina & 1,00 & 0,09 & 0,06 & 0,18 & 0,33 & 0,15 \\
\hline Myroxylon peruiferum & 1,00 & 0,09 & 0,05 & 0,18 & 0,32 & 0,14 \\
\hline
\end{tabular}


Tabela 4. Parâmetros fitossociológicos para as espécies amostradas em Floresta Estacional Semidecidual em Gália, SP. (área B). Dens. Abs. Densidade Absoluta, Dens.Rel.-Densidade Relativa(\%), Dom.Rel.- Dominância Relativa(\%), Freq.Rel.- Freqüência Relativa(\%), IVI - Índice de Valor de Importância e IVC - Índice de Valor de Cobertura.

\begin{tabular}{lcccccc}
\hline \multicolumn{1}{c}{ Dens. Abs. } & $\begin{array}{c}\text { Dens. } \\
\text { Rel. }\end{array}$ & $\begin{array}{c}\text { Dom. } \\
\text { Rel. }\end{array}$ & $\begin{array}{c}\text { Freq. } \\
\text { Rel. }\end{array}$ & IVI & IVC & \\
\hline Neomytranthes sp & 1,00 & 0,09 & 0,03 & 0,18 & 0,30 & 0,12 \\
Ficus insipida & 1,00 & 0,09 & 0,03 & 0,18 & 0,30 & 0,12 \\
Sorocea bonplandii & 1,00 & 0,09 & 0,02 & 0,18 & 0,29 & 0,11 \\
Caseania & & & & & & \\
gossypiosperma & 1,00 & 0,09 & 0,02 & 0,18 & 0,29 & 0,11 \\
Zanthoxyllum fagara & 1,00 & 0,09 & 0,02 & 0,18 & 0,29 & 0,11 \\
Picraminia warmigiana & 1,00 & 0,09 & 0,02 & 0,18 & 0,29 & 0,11 \\
Aspidosperma & & & & & & \\
cylindrocarpum & 1,00 & 0,09 & 0,01 & 0,18 & 0,28 & 0,10 \\
Piptocarpha sellowii & 1,00 & 0,09 & 0,01 & 0,18 & 0,28 & 0,10 \\
Piptocarpha axilaris & 1,00 & 0,09 & 0,01 & 0,18 & 0,28 & 0,10 \\
Piper arboreum & 1,00 & 0,09 & 0,01 & 0,18 & 0,28 & 0,10 \\
Inga marginata & 1,00 & 0,09 & 0,01 & 0,18 & 0,28 & 0,10 \\
Endlicheria paniculata & 1,00 & 0,09 & 0,01 & 0,18 & 0,28 & 0,10 \\
Campomanesia & & & & & & \\
guazumiaefolia & 1,00 & 0,09 & 0,01 & 0,18 & 0,28 & 0,10 \\
Calliandra foliolosa & 1,00 & 0,09 & 0,01 & 0,18 & 0,28 & 0,10 \\
lxora venulosa & 1,00 & 0,09 & 0,01 & 0,18 & 0,28 & 0,10 \\
Pilocarpus pennatifolius & 1,00 & 0,09 & 0,01 & 0,18 & 0,28 & 0,10 \\
\hline
\end{tabular}


Por ocasião das coletas de campo do levantamento florístico da reserva para elaboração da chave de identificação das espécies arbóreas, observau-se que havia diferenças marcantes na distribuição de algumas espécies entre os dois trechos de amostragem fitossociológica. Verificou-se, por exemplo, uma grande diferença na distribuição da espécie Metrodorea nigra entre ambientes, não ocorrendo essa diferença para Savia dyctiocarpa. Nas áreas dos baixios com altitude aproximada de $580 \mathrm{~m}$, observou-se uma alta densidade de Metrodorea nigra no subosque, ao passo que nos topos com altitude aproximada de $660 \mathrm{~m}$, não foi observado nenhum indivíduo de $M$. nigra. Este nicho foi ocupado por Actinostemon concepcionis (com alta densidade no planalto e baixa na planície) e $S$. dyctiocarpa (com alta densidade nas duas áreas). Estas observações foram confirmadas pele análise fitossociológica.

As 10 espécies de maior IVI para os trechos de floresta da Estação Ecológica dos Caetetus são:

Para (Área A) Savia dyctiocarpa (63,94); Actinostemon concepcionis (25,02); Astronium graveolens (17,39); Piptadenia gonoacantha (13,73); Croton floribundus (13,39); Aspidosperma polyneuron (10,71); Inga striata $(8,91)$; Ocotea indecora $(7,82)$; Myrcia fallax $(6,95)$ e Margaritaria nobilis $(6,53)$ (Figura 5).

Para(Área B) Metrodorea nigra (69,36); Savia dyctiocarpa $(57,10)$; Ocotea indecora (21,66); Aspidosperma polyneuron $(17,65)$; Trichilia catigua (12,00); Chrysopyllum gonocarpum (7,51); Syagrus rommanzoffiana $(6,64)$; Croton floribundus $(5,430)$, Gallesia integrifolia $(5,34)$ e Cabralea canjerana $(4,98)$ (Figura 6).

Destes dados destacam-se os seguintes: Savia dyctiocarpa possui alto IVI nas duas áreas, sendo a primeira classificada na (área A) e isto se deve à sua maior dominância relativa e expressivas densidade e freqüência relativas. Metrodorea nigra supera Savia dyctiocarpa na (área B), devido a sua maior densidade e freqüência relativa; por outro lado, Metrodorea nigra não está representada na (área A). Actinostemon concepcionis, segunda classificada na 
área A, ocupa a $36^{a}$ classificação na (área B), que é ocupada predominantemente neste nicho espacial por Metrodorea nigra.

$\mathrm{Na}$ (área A) ocorreram duas espécies pioneiras entre as 10 de maior IVI: Piptadenia gonoacantha e Croton floribundus, em $4^{\mathrm{a}}$ e $5^{\mathrm{a}}$ posições respectivamente. Na (área B), apenas Croton floribundus, como espécie pioneira, ocupa a $8^{\mathrm{a}}$ posição, denotando que na área $\mathrm{A}$ houve maior incidência de clareiras que hoje são ocupadas por indivíduos adultos de espécies pioneiras, dados os significativos valores de dominância relativa dessas espécies.

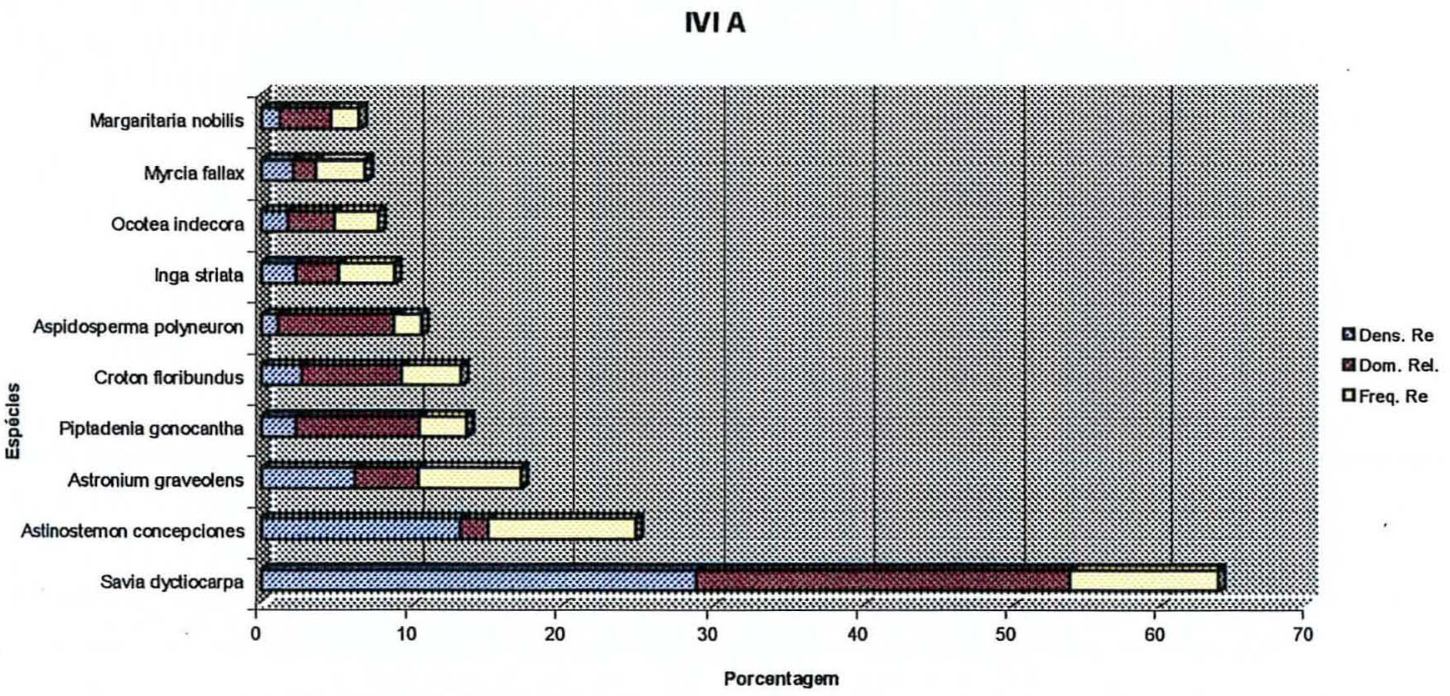

Figura 5 - Figura ilustrativa das 10 espécies de maior IVI na (área A) e suas respectivas densidade, dominância e freqüência relativas . 
IVI B

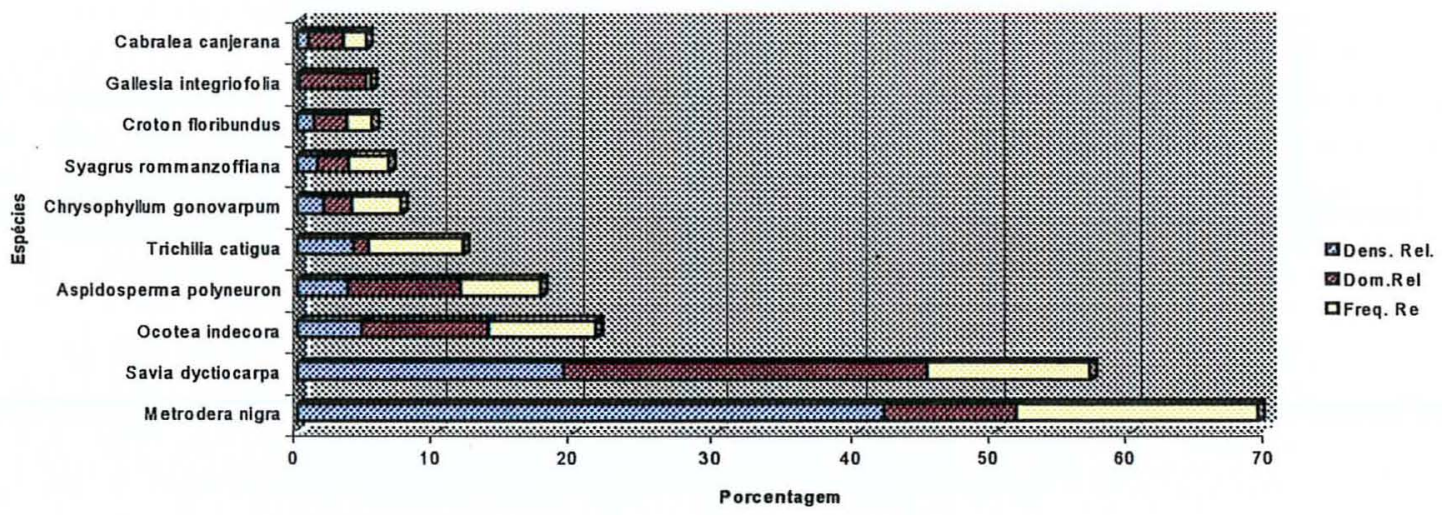

Figura 6 - Figura ilustrativa das 10 espécies de maior IVI na (área B) e suas respectivas densidade, dominância e freqüência relativas .

Distribuição diamétrica das espécies mais densas no levantamento fitossociológico dos dois trechos de floresta da E. E. dos Caetetus.

A amostragem fitossociológica de 1 ha tem como objetivo amostrar as espécies de maior densidade, sendo seus resultados impróprios para espécies de baixa densidade. Dessa forma, optamos por ilustrar graficamente para as áreas (A) e (B) apenas as espécies com número de indivíduos superior a trinta.

Nota-se na (área A) que, com exceção de Croton floribundus, espécie pioneira, todas as outras espécies tiveram distribuição diamétrica de $(\mathrm{J})$ (figuras $7,8,9$ e 11) invertido, semelhante àquela das comunidades, ao passo que Croton floribundus apresentou distribuição normal (fig. 10). Isto pode ser explicado pelo tipo de colonização em clareiras, não havendo muitos indivíduos jovens, como é o caso das espécies de interior da floresta que possuem um grande número de indivíduos jovens no subosque. Na (área B) todas as espécies mais densas apresentam o tipo de distribuição diamétrica de $(\mathrm{J})$ 
invertido. Este fato corrobora a idéia de que a (área B) esteja em melhor estado de conservação (figuras 12 a 16).

Distribuição diamétrica das espécies com mais de 30 indivíduos por hectare na (Área A)

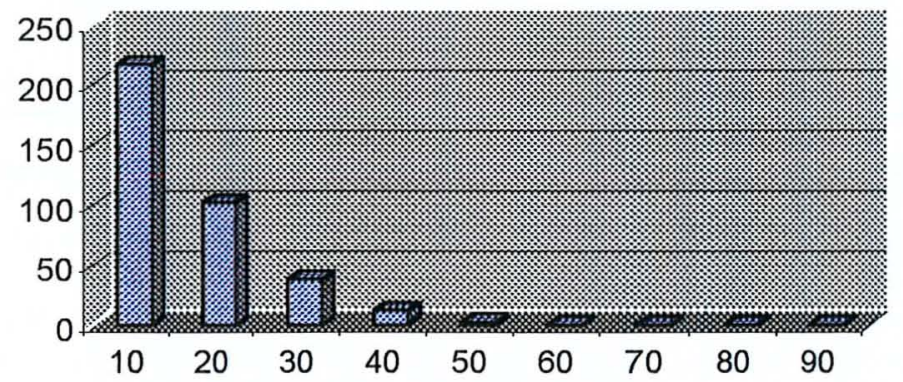

Figura 7 - Distribuição diamétrica de Savia dyctiocarpa (371 indivíduos por hectare). Eixo $Y=$ número de indivíduos e Eixo $X=$ classes de diâmetro $(\mathrm{cm})$.

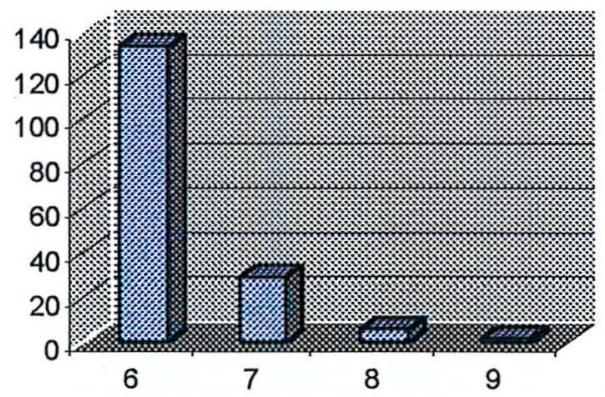

Figura 8 - Distribuição diamétrica de Actinostermon concepcionis (170 indivíduos por hectare). Eixo $\mathrm{Y}=$ número de indivíduos e Eixo $\mathrm{X}=$ classes de diâmetro $(\mathrm{cm})$. 


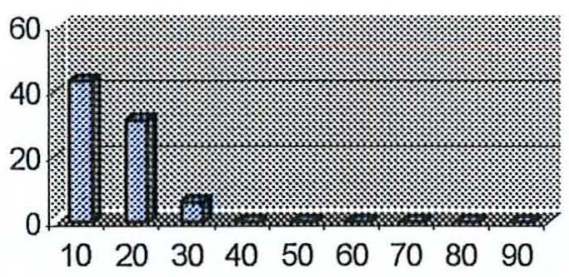

Figura 9 - Distribuição diamétrica de Asgronium graveolens (80 indivíduos por hectare). Eixo $\mathrm{Y}=$ número de indivíduos e Eixo $\mathrm{X}=$ classes de diâmetro $(\mathrm{cm})$.

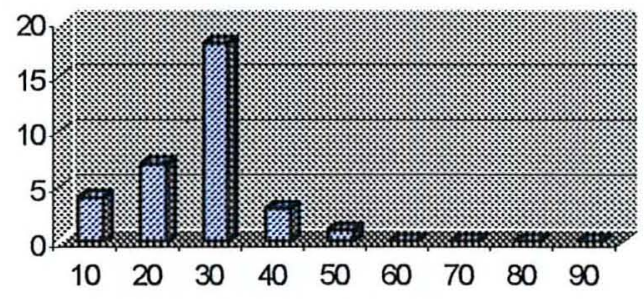

Figura 10 - Distribuição diamétrica de Croton floribundus (33 indivíduos por hectare). Eixo $\mathrm{Y}=$ número de indivíduos e Eixo $\mathrm{X}=$ classes de diâmetro $(\mathrm{cm})$.

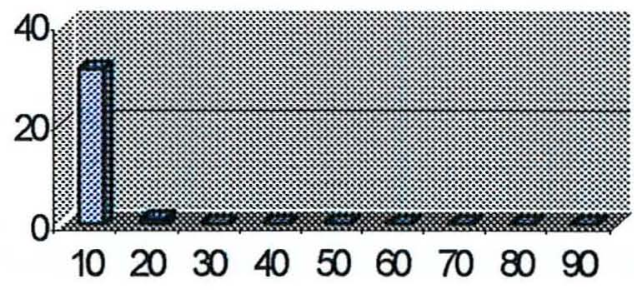

Figura 11 - Distribuição diamétrica de Pilocarpus pauciflorus (32 indivíduos por hectare). Eixo $Y=$ número de indivíduos e Eixo $X=$ classes de diâmetro $(\mathrm{cm})$. 
Distribuição diamétrica das espécies com mais de 30 indivíduos por hectare na (Área B).

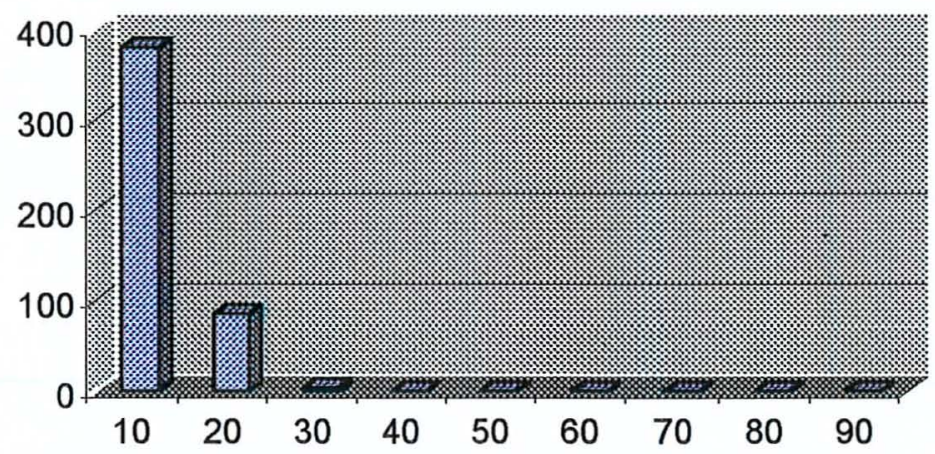

Figura 12 - Distribuição diamétrica de Metrodorea nigra (468 indivíduos por hectare). Eixo $Y=$ número de indivíduos e Eixo $X=$ classes de diâmetro $(\mathrm{cm})$.

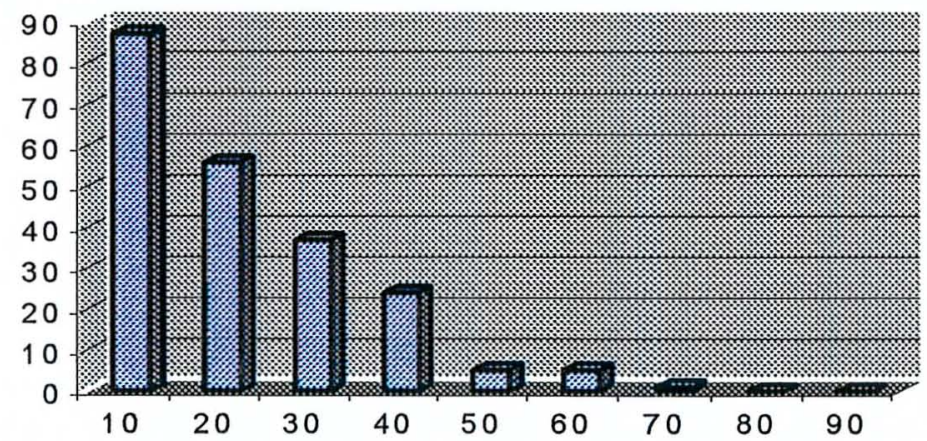

Figura 13 - Distribuição diamétrica de Savia dyctiocarpa (215 indivíduos pó hectare). Eixo $Y=$ número de indivíduos e Eixo $X=$ classes de diâmetro $(\mathrm{cm})$. 


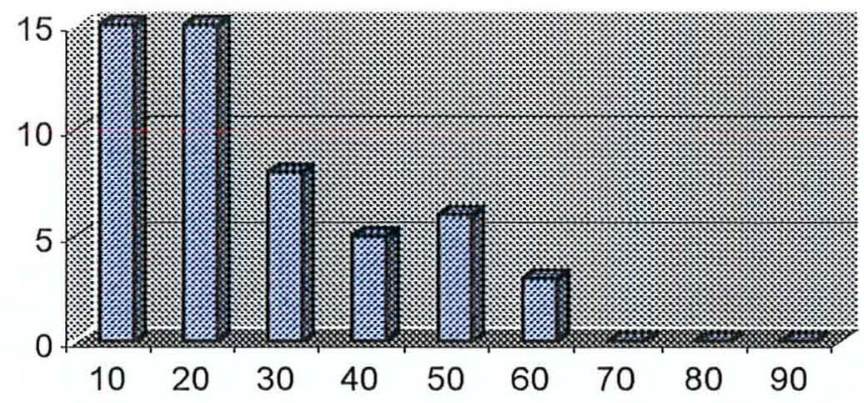

Figura 14 - Distribuição diamétrica de Ocotea indecora (52 indivíduos por hectare). Eixo $Y=$ número de indivíduos e Eixo $X=$ classes de diâmetro $(\mathrm{cm})$.

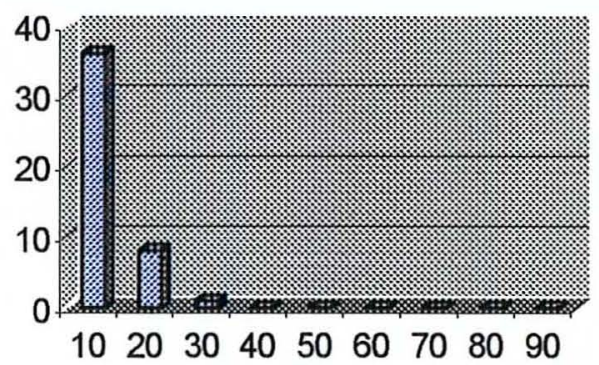

Figura 15 - Distribuição diamétrica de Trichilia catigua (45 indivíduos por hectare). Eixo $Y=$ número de indivíduos e Eixo $X=$ classes de diâmetro $(\mathrm{cm})$.

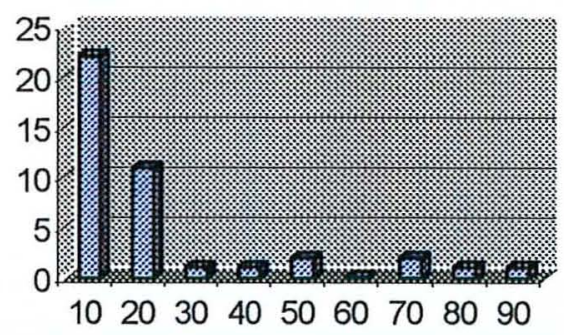

Figura 16 - Distribuição diamétrica de Aspidosperma polyneuron (41 indivíduos por hectare). Eixo $\mathrm{Y}=$ número de indivíduos e Eixo $\mathrm{X}=$ classes de diâmetro (cm). 
A amostragem de 2 hectares para o levantamento fitossociológico corresponde a $0,09 \%$ da área total da reserva, no entanto amostrou $52,17 \%$ das espécies da reserva, valor próximo ao encontrado por Rozza (1997), que, em sua análise fitossociológica de duas áreas no município de Matão, SP, encontrou $50 \%$ das espécies relacionadas no levantamento florístico. Excluindo-se as espécies heliófitas e higrófitas, que são pouco freqüentes no interior de mata, obtivemos cerca de $70 \%$ das espécies mais freqüentes no interior da mata, demonstrando, assim, a eficiência do método utilizado.

\subsection{Similaridade e estratificação entre os trechos de floresta}

A baixa similaridade existente entre florestas estacionais semideciduais decorre do número elevado de espécies com um ou poucos indivíduos no campo amostral (Pagano et al., 1995). Esta afirmação é válida quando se utilizam índices de similaridade que consideram apenas a presença $e$ ausência onde espécies de baixa densidade têm mesmo peso que as de alta densidade. A estrutura fitossociológica, a grande diversidade e riqueza florística podem ser a razão para que florestas contíguas ou muito próximas demonstrem alta heterogeneidade florística e estrutural (Bertoni1984). A análise de similaridade florística pode ser muito influenciada pelos métodos de amostragem, ou seja, número de unidades amostrais, critérios de inclusão, histórico de perturbação, gradientes ambientais e a dinâmica de clareiras naturais (César, 1988).

Procurou-se, neste estudo, restringir as variáveis ambientais às características físico-químicas do solo. Porém, fatores como umidade, topografia e luminosidade não foram medidos, mas certamente têm grande contribuição 
nessa heterogeneidade. Na discussão dos resultados apresentados procurouse, também, considerar essas variáveis.

O índice de similaridade de Jaccard foi de $33 \%$ entre as comunidades das áreas ( $A$ e B), ou seja, superior a $25 \%$ indicado na bibliografia para considerar duas comunidades como similares (Müller-Dombois \& Ellenberg, 1994).

Durante os trabalhos de campo notou-se que nas áreas $\mathrm{A}$ e $\mathrm{B}$ havia uma grande densidade de poucas espécies no subosque, que não eram as mesmas para as duas áreas, sugerindo que a diferença entre as áreas poderia estar restrita a um dos estratos e não à floresta como um todo.

No gráfico elaborado para verificar a distribuição do número de indivíduos por classes de altura, com intervalos de $2 \mathrm{~m}$ e amplitude de 2 a $36 \mathrm{~m}$, das áreas $A$ e $B$, verificou-se que havia uma grande diferença no número de indivíduos nas classes entre 10 e 14m (Figura 17).

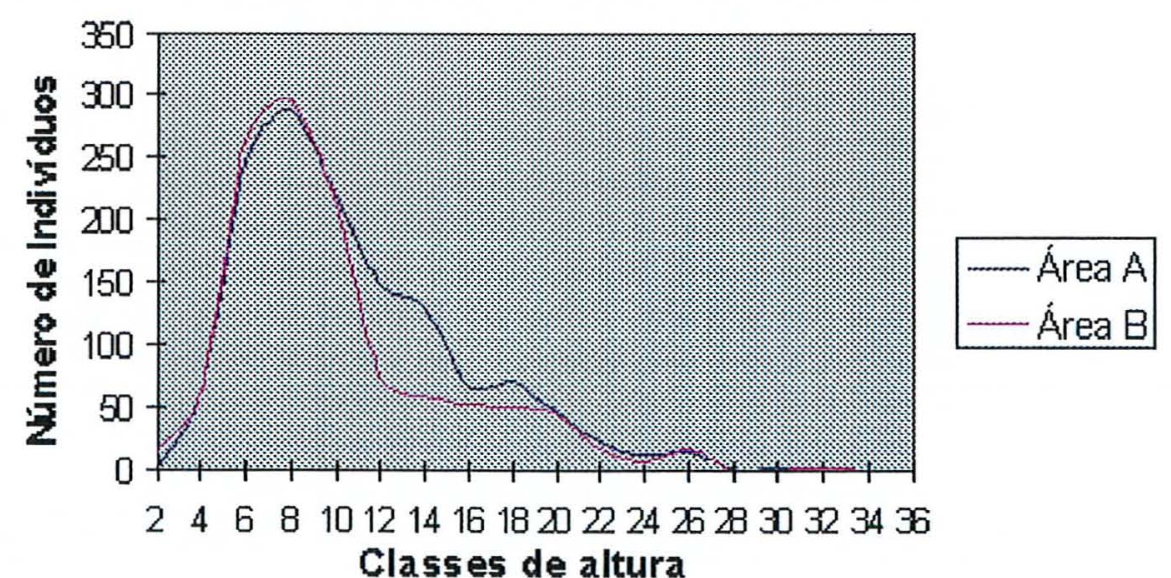

Classes de altura

Figura 17 - Distribuição do número de indivíduos dos dois trechos de floresta da E. E. dos Caetetus, por classes de altura, de dois em dois metros. 
Para as análises de similaridade florística de Jaccard entre os três intervalos de altura $\leq 10 \mathrm{~m} ;>10 \mathrm{~m}, \leq 14 \mathrm{~m}$ e $>14 \mathrm{~m}$. Os resultados encontrados foram: $27 \%, 23 \%$ e $30 \%$, respectivamente. Todos esses valores de similaridade (Jaccard) foram inferiores ao valor das comunidades como um todo, que foi de $33 \%$. Porém, os valores do primeiro e terceiro estratos podem ser considerados similares, conforme recomendação da literatura para valores $\geq$ a $25 \%$ (MuellerDombois \& Ellenberg, 1994). Estes valores, apesar de próximos, indicam uma tendência de maior similaridade entre as comunidade de dossel do que entre as comunidades de subosque. Consideramos, também, que as espécies do dossel poderiam estar aumentando a similaridade no subosque das áreas $\mathrm{A}$ e $\mathrm{B}$ devido aos indivíduos jovens, sendo que o mesmo não ocorre para o dossel porque as espécies de subosque nunca ocupam este estrato. Para isso, excluímos da análise as espécies do dossel que estavam presentes no subosque. Com isso, obtivemos apenas $18 \%$ de similaridade. Esta diferença confirma nossa hipótese de que há maior homogeneidade no dossel que no subosque quando comparadas as comunidades das áreas $(A)$ e $(B)$.

Além das análises de similaridade, considerando-se presença e ausência, como o Índice de Jaccard, optou-se também pelo de dissimilaridade considerando a densidade das espécies como, neste caso, o Índice de BrayCurtis. Estes índices foram aplicados para a comunidade como um todo, assim como para os três estratos separadamente. Para as comunidades analisadas, os índices de Jaccard e Bray-Curtis separam nitidamente A e B (Figuras 18 e 19), ou seja, são comunidades distintas. Esta separação pode ser explicada pelas altas densidades e freqüências de Metrodorea nigra na área $\mathrm{B}$, o mesmo ocorrendo com Actinostemon concepcionis na área $\mathrm{A}$.

Podemos observar que o dendrograma da comunidade geral (Figuras 18 e 19) é determinado pelos indivíduos do primeiro estrato, que totalizam 1598 indivíduos, o que corresponde a 66,78\% deste total. Deste total, 446 indivíduos são da espécie Metrodorea nigra, todos ocorrentes na área B; 170 indivíduos são da espécie Actinostemon concepcionis, dos quais 166 
ocorrentes na área $\mathrm{A}$ e os restantes na área $\mathrm{B} ; 303$ indivíduos são da espécie Savia dyctiocarpa, sendo 203 na área A e 100 na área B. Apenas estas três espécies totalizam, neste estrato, 839 indivíduos, o que corresponde a 52,50\% do total de individuos deste estrato (Figuras 20 e 21).

O estrato intermediário apresenta 380 indivíduos nas duas áreas, sendo que a área $A$ possui 265 indivíduos, correspondendo a $69,74 \%$ do total deste estrato e 115 estão na área B, o que corresponde a 30,26\%. Dos 265 indivíduos da área A, $88(33,20 \%)$ são da espécie Savia dyctiocarpa, ao passo que na área $B$ apenas $36(31,30 \%)$ são desta espécie. Os dendrogramas deste estrato não apresentam nitidez na separação de grupos (maior mistura entre parcelas das áreas $A$ e $B$ ) quando se utilizam os de Bray-Curtis e de Jaccard (Figuras 22 e 23).

O terceiro estrato apresenta 415 indivíduos, dos quais 159 (38,31\%) são da espécie Savia dyctiocarpa, sendo 80 ocorrentes na área A e 79 na área $B$. Neste estrato, que só contém espécies próprias de dossel, fica ainda mais nítida a maior semelhança das comunidades, tanto qualitativamente (Jaccard) quanto quantitativamente (Bray-Curtis) (Figuras 24 e 25). 


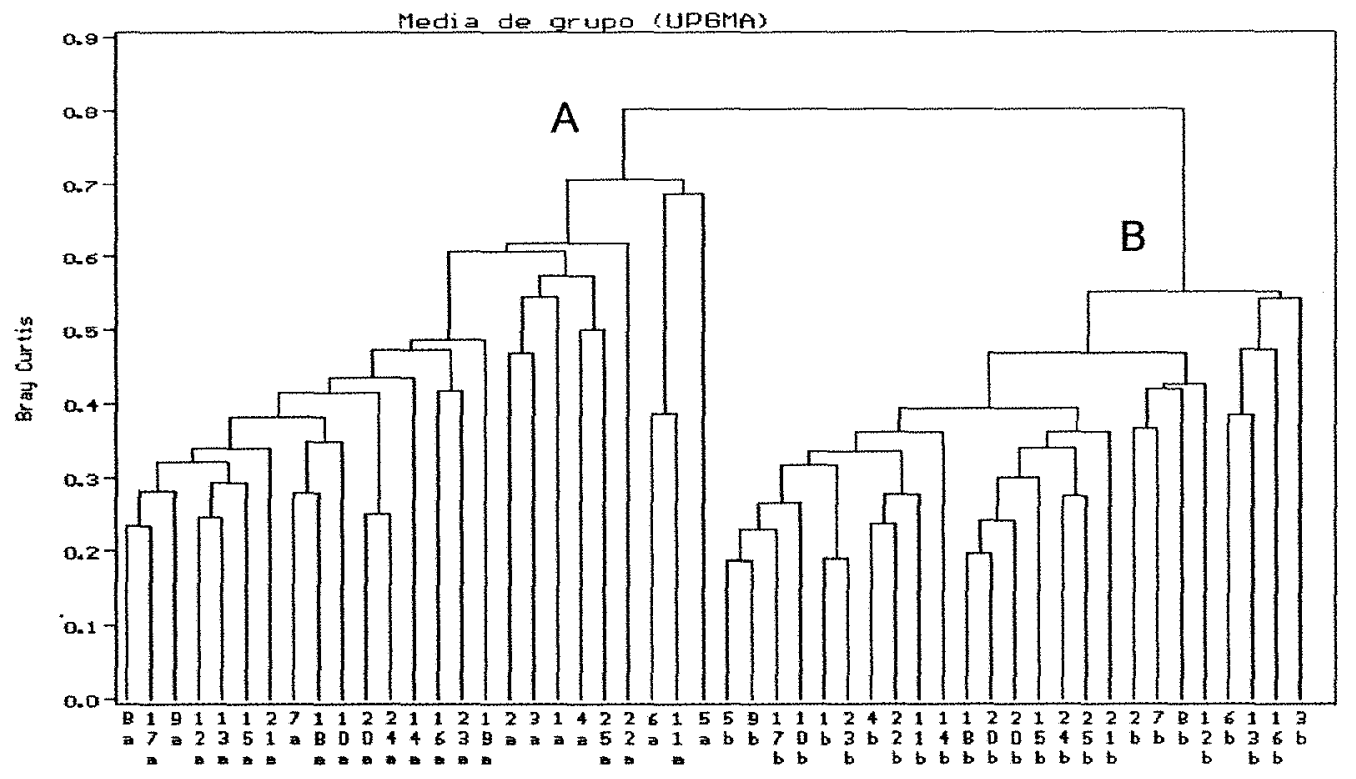

Figura 18 - Análise de dissimilaridade da comunidade geral (Bray Curtis), para as áreas A e B da Estação Ecológica dos Caetetus.

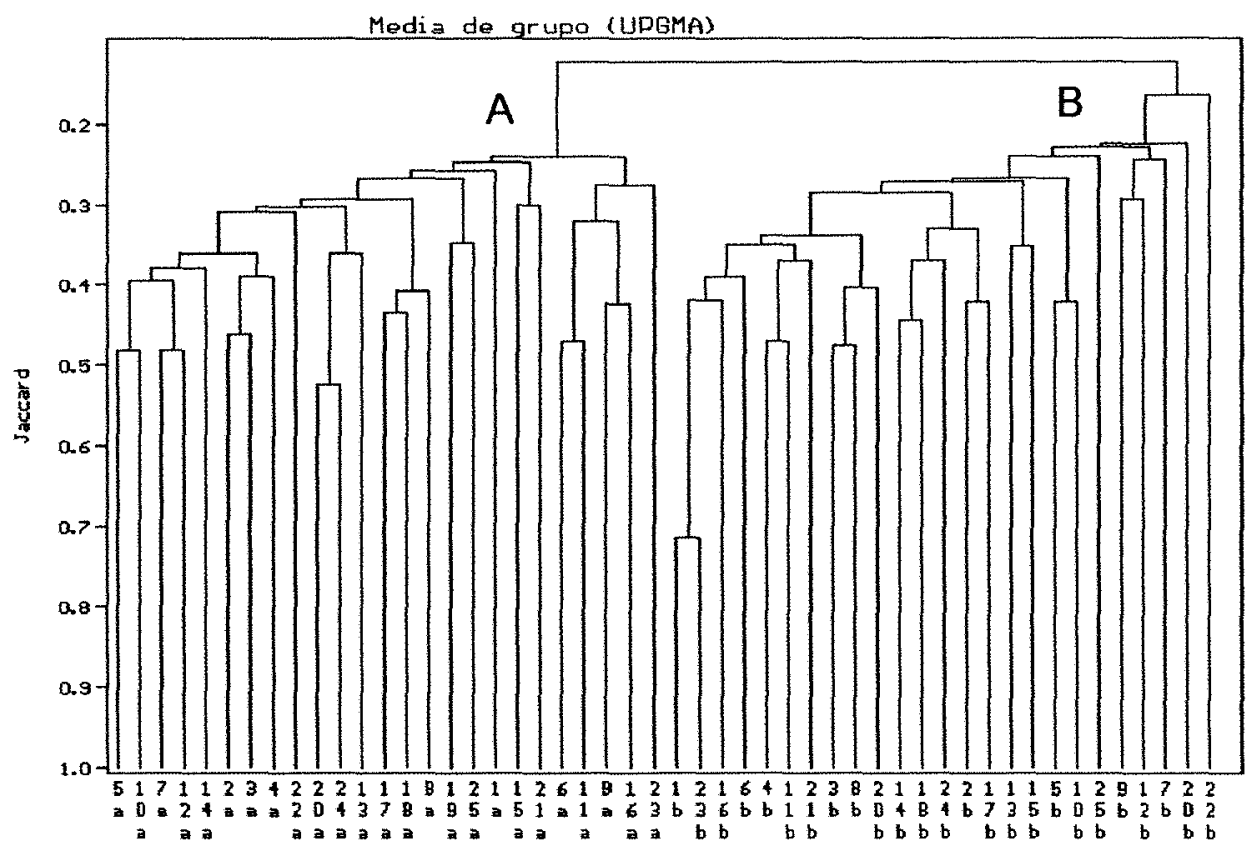

Figura 19 - Análise de similaridade da comunidade geral (Jaccard), para as áreas A e B da Estação Ecológica dos Caetetus. 


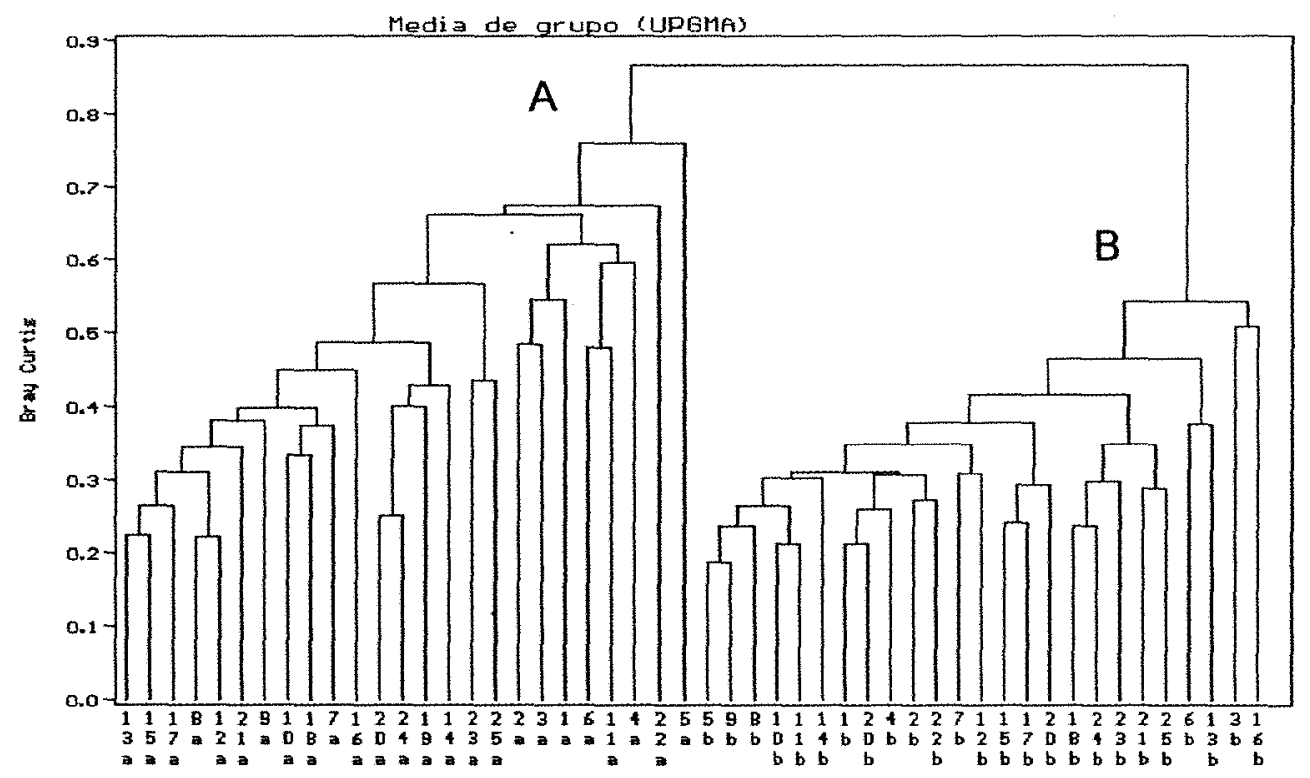

Figura 20 - Análise de dissimilaridade com altura $\leq 10 \mathrm{~m}$ (Bray Curtis), para as áreas A e B da Estação Ecológica dos Caetetus.

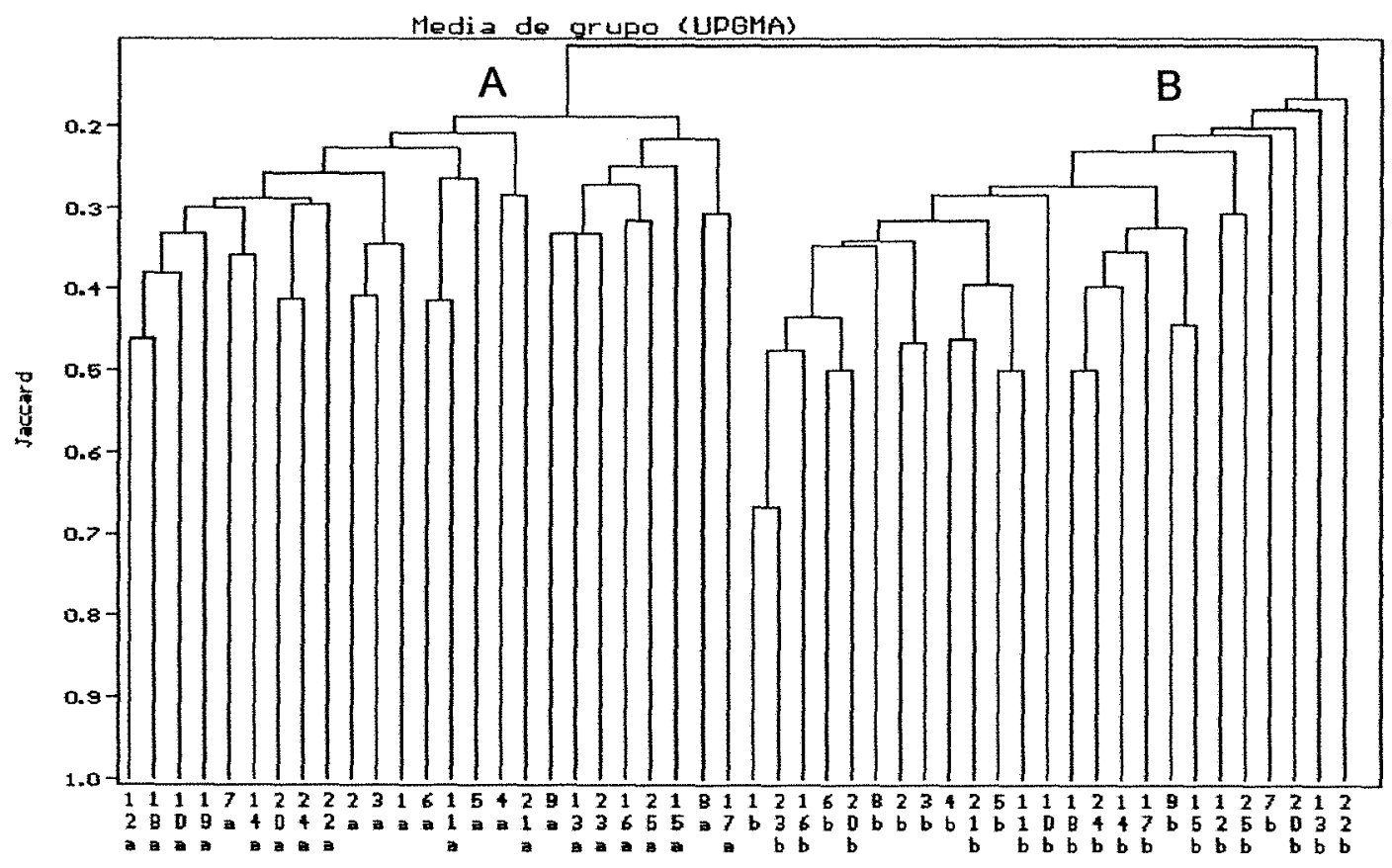

Figura 21 - Análise de dissimilaridade com altura $\leq 10 \mathrm{~m}$ (Jacard), para as áreas A e B da Estação Ecológica dos Caetetus. 


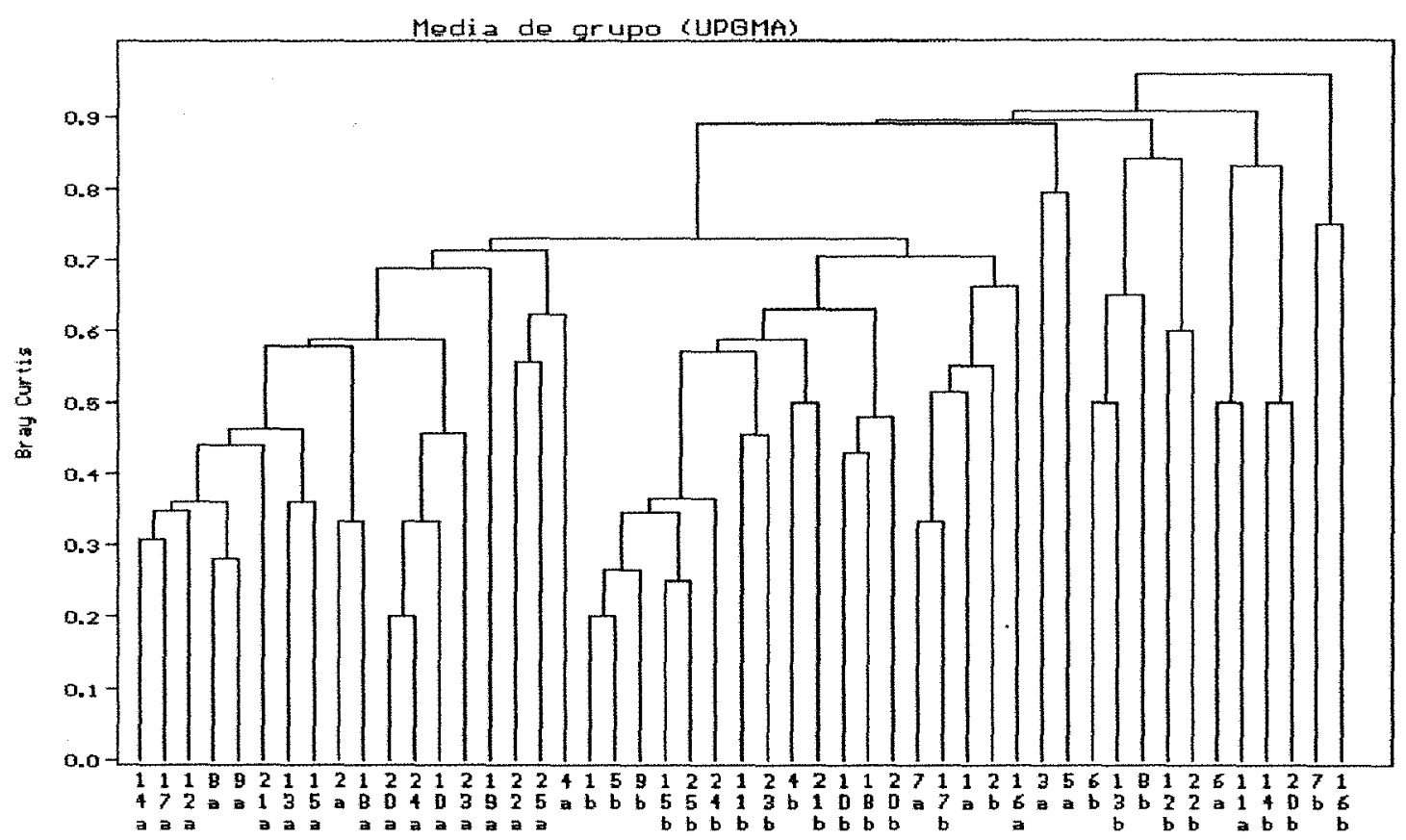

Figura 22 - Análise da dissimilaridade entre alturas $>10$ e $\leq 14 \mathrm{~m}$ (Bray Curtis), para as áreas A e B da Estação Ecológica dos Caetetus.

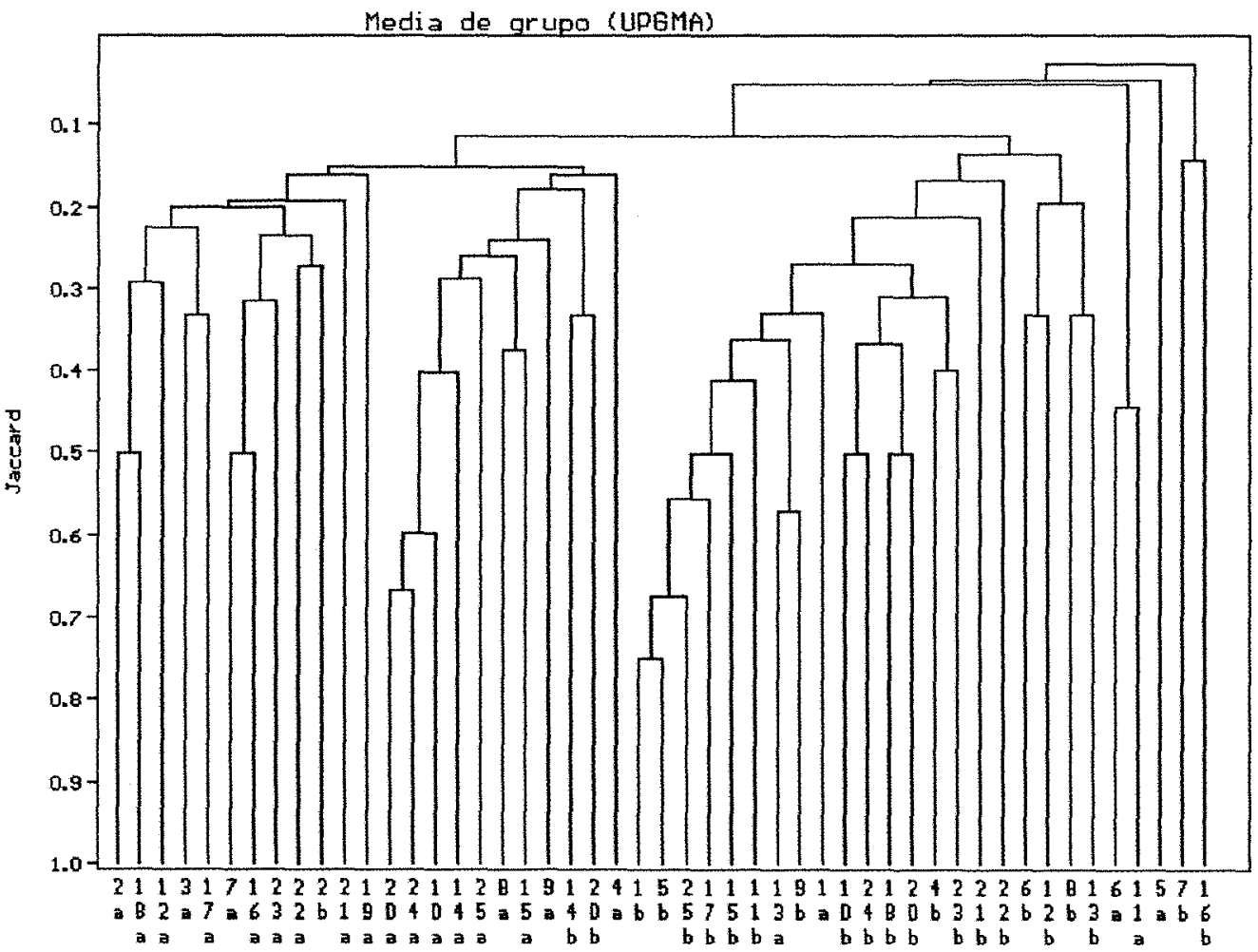

Figura 23 - Análise de similaridade entre alturas $>10$ e $\leq 14 \mathrm{~m}$ (Jaccard), para as áreas A e B da Estação Ecológica dos Caetetus. 


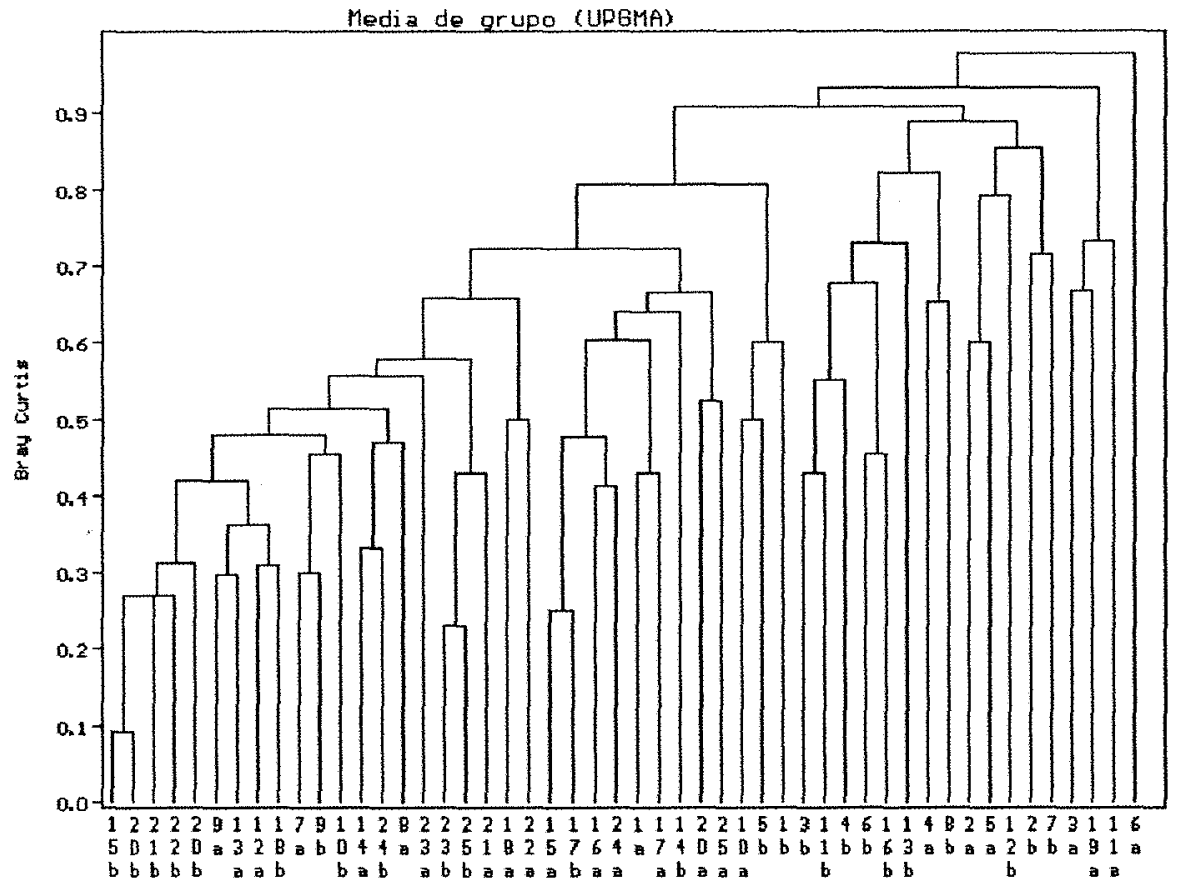

Figura 24 - Análise de dissimilaridade entre alturas >14 metros (Bray Curtis), para as áreas A e B da Estação Ecológica dos Caetetus.

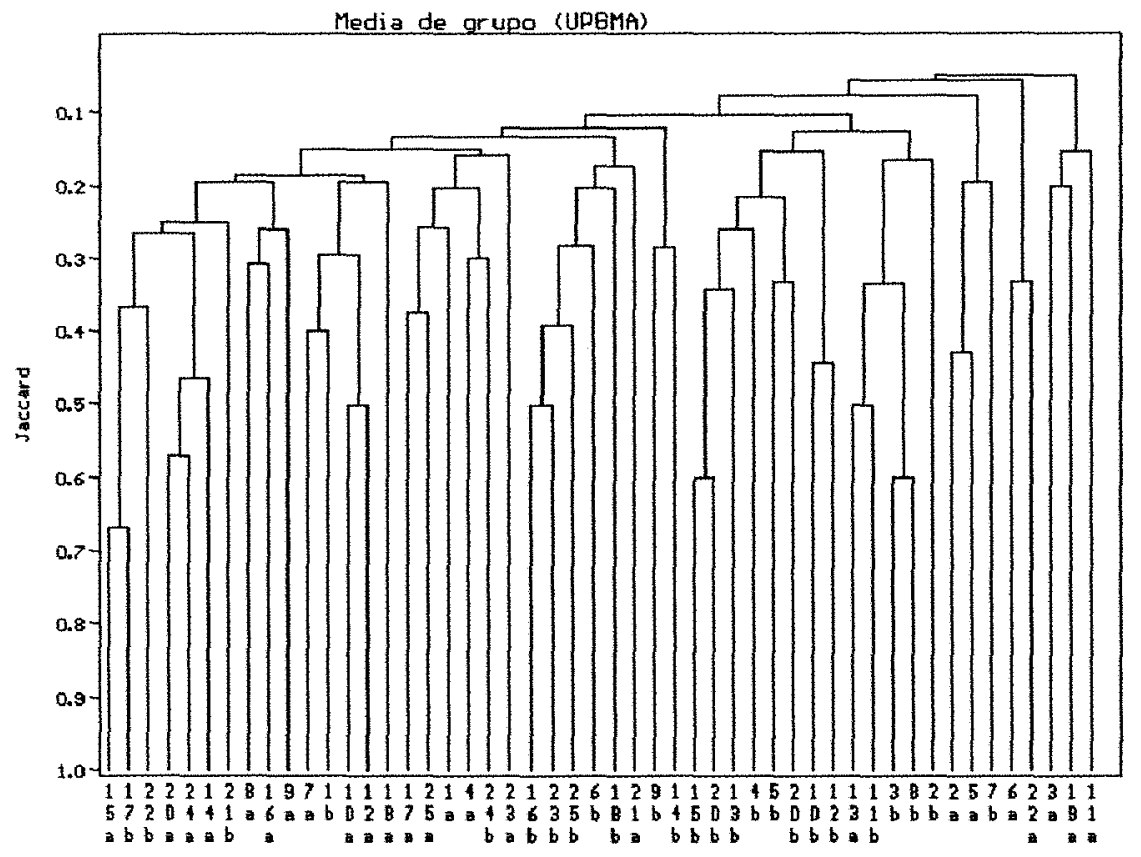

Figura 25 - Análise de similaridade entre altura > que 14 metros (Jaccard), para as áreas $A$ e $B$ da Estação Ecológica dos Caetetus. 
Para detectar as espécies de maior influência nos dendrogramas de Bray-Curtis, foi feito um corte arbitrário na comparação dos estratos das áreas $A$ e $B$. Este corte foi denominado de discrepância $\geq 5$, ou seja, foram apenas consideradas nas análises as espécies por estrato que em uma das áreas contivessem número de indivíduos $\geq$ em relação a outra área. Considerou-se, então, que as espécies com menor discrepância seriam coadjuvantes na formação dos dendrogramas e não foram utilizadas nas análises (Tabelas 5, 6 e 7).

Nas discrepâncias do estrato inferior (tabela 5), verificamos 29 espécies com somatória de igual a 1061. Nos estratos intermediários (tabela 6) verificamos 17 espécies com somatória igual a 189 . E no estratos superiores (tabela 7), 14 espécies com somatória de discrepância igual a 102. Estes valores mostram que há uma maior discrepância nos estratos inferiores e que reforça a hipótese de que este estrato é o maior diferenciador das comunidades e que Metrodorea nigra, Savia dyctiocarpa e Actenostemon concepcionis são as principais espécies nesta diferenciação. 
Tabela 5. Lista de espécies do estrato inferior com discrepância $>5$ para as áreas $\mathrm{A}$ e $\mathrm{B}$. NA = número de indivíduos por espécie da área $\mathrm{A}$ e $\mathrm{NB}=$ número de indivíduos por espécie da área $B$. Discrepância $=$ diferença $>5$ no número de indivíduos entre as espécies das áreas A e B.

\begin{tabular}{lccc}
\hline \multicolumn{1}{c}{ Espécie } & NA & NB & Discrepância \\
\hline Metrodorea nigra & & 446 & 446 \\
Actinostemon concepcionis & 170 & 4 & 166 \\
Savia dyctiocarpa & 203 & 100 & 103 \\
Astronium graveolens & 49 & 5 & 44 \\
Tapirira guianensis & & 40 & 40 \\
Pilocarpus pauciflorus & 31 & 3 & 28 \\
Zanthoxyllum pohlianum & 24 & & 24 \\
Aspidosperma polyneuron & 7 & 30 & 23 \\
Ocotea indecora & 9 & 26 & 17 \\
Aparisthmium cordatum & 15 & & 15 \\
Calyptranthes clusiaefolia & 13 & & 13 \\
Chrysophyllum gonocarpum & 1 & 14 & 13 \\
Zanthoxyllum juniperinum & 23 & 11 & 12 \\
Inga striata & 12 & & 12 \\
Myrcia fallax & 11 & & 11 \\
Esenbeckia grandiflora & 9 & & 9 \\
Xylopia brasiliensis & 9 & & 9 \\
Casearia gossypiosperma & 10 & 1 & 9 \\
Ocotea corymbosa & 8 & & 8 \\
Trichilia claussenii & & 8 & 8 \\
Zeyhera tuberculosa & 8 & 1 & 7 \\
Maprounea guianensis & 7 & & 7 \\
Pisonia ambígua & 6 & & 6 \\
Swetia fruticosa & 6 & 3 & 6 \\
Cordia ecalyculata & 8 & & 5 \\
Duguetia lanceolata & 5 & 9 & 5 \\
Piptadenia gonoacantha & 5 & & 5 \\
Mollinedia widgrenii & 4 & & 5 \\
Actinostemon concolor & 2 & & \\
\hline
\end{tabular}


Tabela 6 . Lista de espécies do estrato intermediário com discrepância $>5$ para as áreas $\mathrm{A}$ e B. NA = número de indivíduos por espécie da área $\mathrm{A}$ e $\mathrm{NB}=$ número de indivíduos por espécie da área $\mathrm{B}$. Discrepância $=$ diferença $>5$ no número de indivíduos entre as espécies das áreas $\mathrm{A}$ e $\mathrm{B}$.

\begin{tabular}{lccc}
\hline \multicolumn{1}{c}{ Espécie } & NA & NB & Discrepância \\
\hline Savia dyctiocarpa & 88 & 36 & 52 \\
Metrodorea nigra & & 21 & 21 \\
Astronium graveolens & 18 & 3 & 15 \\
Croton floribundus & 16 & 2 & 14 \\
Myrcia fallax & 12 & & 12 \\
Piptadenia gonoacantha & 10 & & 10 \\
Inga striata & 9 & 1 & 8 \\
Casearia gossypiosperma & 7 & & 7 \\
Xylopia brasiliensis & 6 & & 6 \\
Syagrus rommanzoffiana & 6 & & 6 \\
Margaritaria nobilis & 6 & & 6 \\
Calyptranthes clusiaefolia & 6 & & 6 \\
Alchornea triplinervia & 6 & & 6 \\
Trichilia claussenii & & 5 & 5 \\
Maprounea guianensis & 6 & 1 & 5 \\
Machaerium stipitatum & 5 & & 5 \\
Chrysophyllum gonocarpum & 1 & 6 & 5 \\
\hline
\end{tabular}


Tabela 7 . Lista de espécies do estrato superior com discrepância $>5$ para as áreas $\mathrm{A}$ e $\mathrm{B}$. $\mathrm{NA}=$ número de indivíduos por espécie da área $\mathrm{A}$ e $\mathrm{NB}=$ número de indivíduos por espécie da área $B$. Discrepância $=$ diferença $>5$ no número de indivíduos entre as espécies das áreas $\mathrm{A}$ e $\mathrm{B}$.

\begin{tabular}{lccc}
\hline \multicolumn{1}{c}{ Espécie } & NA & NB & Discrepância \\
\hline Piptadenia gonoacantha & 15 & 1 & 14 \\
Syagrus rommanzoffiana & 3 & 16 & 13 \\
Astronium graveolens & 13 & 3 & 10 \\
Mabea fistulifera & 9 & & 9 \\
Inga striata & 9 & 1 & 8 \\
Ocotea indecora & 4 & 11 & 7 \\
Marganitaria nobilis & 6 & & 6 \\
Casearia gossypiosperma & 5 & & 5 \\
Myrcia fallax & 5 & & 5 \\
Maprounea guianensis & 5 & & 5 \\
Didymopanax morototoni & 5 & & 5 \\
Colubrina glandulosa & 5 & & 5 \\
Parapiptadenia rigida & & 5 & 5 \\
Syagrus oleracea & & 5 & 5 \\
\hline
\end{tabular}




\section{CONCLUSÕES}

O método de caminhadas por trilhas, aliado a incursões ao interior da floresta por diferentes habitats do mosaico ambiental, amostrou 234 espécies arbóreas, maior número de espécies arbóreas relacionadas para o oeste do estado de São Paulo.

A amostragem de dois hectares para o levantamento fitossociológico corresponde a apenas $0,09 \%$ da área total da reserva. No entanto, foram amostradas $52,17 \%$ das espécies da Estação. Consideramos esta área de amostragem bastante eficiente para as espécies arbóreas de interior de floresta. Esta eficiência é ainda maior (chegando a cerca de 70\%) se excluirmos da análise as espécies heliófitas e higrófitas do levantamento florístico que ocorreram em situações muito específicas do ambiente, não sendo contempladas nos dois hectares de área amostral (áreas A e B). Podemos considerar, a partir destes resultados, que, implantando-se mais parcelas em novas situações do ambiente da Reserva, como bordas da mata, áreas com encharcamento e outras, que a eficiência deste método será ainda mais alta.

As espécies dominantes do dossel também estão presentes nos estratos inferiores, mascarando as diferenças florísticas entre os estratos. Para espécies de estratos inferiores existem limites nítidos. Por exemplo, Actinostemon concepcionis não ultrapassou $7 \mathrm{~m}$ de altura e Metrodorea nigra dificilmente ultrapassa $14 \mathrm{~m}$ de altura. $O$ mesmo não ocorre para as espécies de dossel que estão presentes no subosque, excluindo-se da análise as espécies de dossel, o Índice de Similaridade de Jaccard cai de $27 \%$ para $18 \%$, ao passo 
que, para o dossel, o mesmo índice foi de $30 \%$, confirmando que há maior homogeneidade no dossel do que no subosque quando comparadas comunidades em diferentes unidades do mosaico ambiental.

Savia dyctiocarpa é a espécie mais importante ao considerarmos as duas áreas, supera Actinostemon concepcionis no primeiro estrato da área $\mathrm{A}$ e só é superada por Metrodorea nigra no primeiro estrato da área B. Analisando-se conjuntamente as duas comunidades, Savia dyctiocarpa supera Metrodorea nigra no número total de indivíduos, uma vez que Metrodorea nigra só está presente na área $\mathrm{B}$.

Os métodos de amostragem utilizados em levantamentos fitossociológicos são normalmente aplicados para caracterizar a diversidade alfa. Quando seus resultados são utilizados para análise de similaridade entre áreas distantes, estes métodos subestimam a similaridade, sendo aconselhada a utilização de métodos de amostragem mais abrangentes que contemplem os vários ambientes do mosaico, ou seja, que amostrem a diversidade beta, ou seja, para cada objetivo deve-se escolher o método adequado com suficiência amostral que permita as comparações desejadas.

Através das análises de Bray-Curtis e Jaccard para o estrato superior, das áreas $\mathrm{A}$ e $\mathrm{B}$, confirmamos a hipótese de que o dossel é qualitativa e quantitativamente mais homogêneo que o subosque. Estas mesmas análises concluem que o subosque das áreas $\mathrm{A}$ e $\mathrm{B}$ são nitidamente diferentes, influenciado consideravelmente a análise geral, sendo isto suficiente para determinar que os dois trechos de floresta sejam considerados diferentes. 


\section{REFERÊNCIAS BIBLIOGRÁFICAS}

BAITELLO, J.B.; PASTORE, J.A.; AGUIAR, O.T.; SÉRIO, F.C.; SILVA, C.E.F. A vegetação arbórea do Parque Estadual do Morro do Diabo, município de Teodoro Sampaio, Estado de São Paulo. Acta Botanica Brasilica, v.1, n.2, p.221-230, 1988.

BERTANI, D.F.; RODRIGUES, R.R.; BATISTA, J.L.F.; SHEPHERD, G.J. Análise temporal da heterogeneidade hlorística e estrutural em uma floresta ribeirinha. Revista Brasileira de Botânica, v.4, n.1, p.11-23, 2001.

BERTONI, J.E.A. Composição florística e estrutura fitossociológica de uma floresta do interior do estado de São Paulo: Reserva Estadual de Porto Ferreira. Campinas, 1984. 196p. Dissertação (Mestrado) - Instituto de Biologia, Universidade Estadual de Campinas.

BERTONI, J.E.A.; STUBBLEBINE, W.H.; MARTINS, F.R.; LEITÃO FILHO, H.F. Nota prévia: comparação fitossociológica das principais espécies de florestas de terra firme e ciliar na Reserva Estadual de Porto Ferreira (SP). In: CONGRESSO NACIONAL SOBRE ESSÊNCIAS NATIVAS, Campos do Jordão, 1982. Anais. Silvicultura em São Paulo, v.16A, pt. 1, p. 563-571, 1982.

CASTANHO FILHO, E.P.; FEIJO, L.F.C. A politica setorial dos recursos naturais para o estado de São Paulo: contribuição à estratégia mundial para a conservação. São Paulo: Coordenadoria de Pesquisas de Recursos Naturais, Secretaria de Agricultura e Abastecimento do Estado de São Paulo, 1987. 131p. 
CAVASSAN, O.; CESAR, O.; MARTINS, F.R. Fitossociologia da vegetação arbórea da Reserva de Bauru. Revista Brasileira de Botânica, v.7, n.2, p.91-106, 1984.

CESAR, O. Composição florística, fitossociologia e ciclagem de nutrientes em Mata Mesófila Semidecídua (Fazenda Barreiro Rico, município de Anhembi, SP). Rio Claro, 1998. 223p. Tese (Livre-Docência) - Departamento de Botânica do Instituto de Biociências, Universidade Estadual Paulista "Júlio de Mesquita".

DE VUONO, Y.S. Fitossociologia do estrato arbóreo da mata do Instituto de Botânica, São Paulo, SP. São Paulo, 1985. 213p. Tese (Doutorado) Instituto de Biociências, Universidade de São Paulo.

DURIGAN, G; LEITÃO FILHO, H.F. Florística e fitossociologia de matas ciliares do oeste paulista. Revista do Instituto Florestal, v.7, n.2, p.197-239, 1995.

DURIGAN, G.; FRANCO, G.A.D.C.; SAITO, M.; BAITELLO, J.B. Fitossociologia de três estratos da vegetação arbórea em floresta primária na Estação Ecológica dos Caetetus, Gália, SP. Revista Brasileira de Botânica, v.23, n.4, p.369-381, 2000.

EITEN, G. Classificação da vegetação do Brasil. Brasília: CNPq., 1983. $305 p$.

FIDALGO, O.; BONONI, V.L.R. (Coord.) Técnicas de coleta, preservação e herborização de material botânico. São Paulo: Instituto de Botânica, 1989. $62 p$.

GANDOLFI, S. História natural de uma floresta estacional semidecidual no município de Campinas (São Paulo, Brasil). Campinas, 2000. 520p. Tese (Doutorado) - Instituto de Biologia, Universidade de Campinas.

GIBBS, P.E.; LEITÃO FILHO, H.F. Floristic composition of an area of gallery forest near Mogi-Guaçu. State of São Paulo. SP. Brazil. Revista Brasileira de Botânica, v.1, n.1, p.151-156, 1978.

HUECK, K. As florestas da América do Sul. São Paulo: Polígono, 1972. 185p. 
INSTITUTO BRASILEIRO DE GEOGRAFIA E ESTATISTIICA. Manual técnico da vegetação brasileira. Rio de Janeiro, 1992. 92p.

IVANAUSKAS, N.M. Caracterização florística e fisionômica da floresta atlântica sobre a Formação Pariquera-Açú, na Zona da Morraria Costeira do Estado de São Paulo. Campinas, 1997. 217p. Dissertação (Mestrado) - Instituto de Biologia, Universidade Estadual de Campinas.

JOLY, A.B. Conheça a vegetação brasileira. São Paulo: EDUSP, 1970. $181 \mathrm{p}$.

KLEIN, R.M. Ecologia da flora e vegetação do Vale do Itajaí. Sellowia, v.31, p.1-164, 1979.

KOEPPEN, W. Climatologia. México: Fondo de Cultura Económica, 1948. $253 p$.

KRONKA, F.; MATSUKUMA, C.K.; NALON, M.A.; DEL CALI, I.H.; ROSSI, M.; MATTOS, I.F.A.; SHIN-IKE, M.S.; PONTINHAS, A.A.S. Inventário florestal do Estado de São Paulo. São Paulo: Instituto Florestal; Secretaria do Meio Ambiente, 1993. 199p.

LEITÃO FILHO, H.F. Aspectos taxonômicos das florestas do Estado de São Paulo. In: CONGRESSO NACIONAL SOBRE ESSÊNCIAS NATIVAS, Campos do Jordão, 1982. Anais. Silvicultura em São Paulo, v.16A, pt. 1, p.197-206, 1982.

MARTINS, F.R. Estrutura de uma floresta mesófila. Campinas: UNICAMP, 1991. 246p.

MATTES, L.A.F. Composição florística de uma floresta do planalto paulista. Bosques dos Jequitibás. Campinas, 1980. 209p. Dissertação (Mestrado) Departamento de Zoologia, Universidade Estadual de Campinas.

MATTOS, I.F.A.; ROSSI, M.; SILVA, D.A.; PFEIFFER, R.M. Levantamento do meio biofísico e avaliação da fragilidade do ecossistema na Estação Ecológica dos Caetetus, SP. Sociedade e Natureza, v.15, p.388-393, 1996.

MUELLER-DOMBOIS, D.; ELLENBERGER, H. Aims and methods of vegetation ecology. New York: John Willey, 1974. 545p. 
NICOLINI-GABRIEL, E.M.; PAGANO, S.N. Composição florística do estrato arbóreo de floresta mesófila semidecídua no município de Jahu, SP. Arquivos de Biologia e Tecnologia, v.35, n.4, p.725-748, 1992.

NICOLINI-GABRIEL, E.M.; PAGANO, S.N. Estrutura fitossociológica do estrato arbóreo de floresta mesófila semidecídua no município de Jahu, SP. Arquivos de Biologia e Tecnologia, v.36, n.1. p.165-184, 1993.

OLIVEIRA, A. de. Diversidade, estrutura e dinâmica do componente arbóreo de uma floresta de terra firme de Manaus, Amazonas. São Paulo, 1997. 187p. Tese (Doutorado) - Departamento de Botânica, Instituto de Biociências, Universidade de São Paulo.

PAGANO, S.M.; LEITÃO FILHO, H.F. Composição florística do estrato arbóreo da mata mesófila semidecídua no município de Rio Claro (Estado de São Paulo). Revista Brasileira de Botânica, v.10, n.1, p.37-147, 1987.

PAGANO, S.N. Estudo florístico, fitossociólogico e de ciclagem de nutrientes em matas mesófila semidecídua no município de Rio Claro, SP. Rio Claro, 1985. 201p. Tese (Livre Docência) - Instituto de Biociências, Universidade de São Paulo.

RIZZINI, C.T. Nota prévia sobre a divisão fitogeográfica do Brasil. Revista Brasileira de Geografia, v.25, n. 1, p.3-64, 1963.

RIZZINI, C.T. Tratado de fitogeografia do Brasil. São Paulo: HUCITEC; EDUSP, 1979. v.2, 374p.

RODRIGUES, R.R. Levantamento florístico e fitossociológico das matas da Serra do Japi, Jundiaí. Campinas, 1986. 198p. Dissertação (Mestrado) Instituto de Biologia, Universidade Estadual de Campinas.

RODRIGUES, R.R. Análise de um remanescente de vegetação natural às margens de Rio Passa Cinco. Ipeúna, SP. Campinas, 1991. 325p. Tese (Doutorado) - Instituto de Biologia, Universidade Estadual de Campinas.

RODRIGUES, R.R.; NAVE, A.G. Heterogeneidade florística das matas ciliares. In: RODRIGUES. R.R.; LEITÃO FILHO, H.F. Matas ciliares: conservação e recuperação. São Paulo: EDUSP, 2000, p.45-71. 
ROZZA, A.F. Florística, fitossociologia e caracterização sucessional em uma floresta estacional semidecidual: Mata da Virgínia, Matão, SP. Campinas, 1997. 149p. Dissertação (Mestrado) - Instituto de Biologia, Universidade Estadual de Campinas.

SALLIS, S.M., SHEPHERD, G.J.; JOLY, C.A. Floristic comparison of mesophytic semideciduous forests of the interior of the state of São Paulo, Southeast Brazil. Vegetatio, v.119, p.155-164, 1995.

SCHLITTLER, F.H.M.; MARTINS, G.; CÉSAR, O. Estudos fitossociológicos na Floresta do Morro do Diabo (Pontal do Paranapanema, SP, Brasil). Arquivos de Biologia e Tecnologia, v.38, n.1, p.217-234, 1995.

SILVA, A.F. Composição florística e estrutura fitossociológica do estrato arbóreo da Reserva Florestal Professor Augusto Ruschi. São Jose dos Campos, SP. Campinas, 1989. 163p. Tese(Doutorado) - Instituto de Biologia, Universidade Estadual de Campinas.

SILVA, A.F.; LEITÃO FILHO, H.F. Composição florística e estrutura de um trecho de Mata Atlântica de encosta no Município de Ubatuba (São Paulo, Brasil). Revista Brasileira de Botânica, v.5, n.2/1, p.43-52, 1982.

SILVA-FILHO, S.R.; ENGEL, V.L. Estrutura de um fragmento de mata mesófila semidecídua secundária tardia e implicações para o manejo. In: CONGRESSO FLORESTAL PANAMERICANO, 1; CONGRESSO FLORESTAL BRASILEIRO, 7., Curitiba, 1993. Anais. São Paulo: SBS; SBEF, 1993. p.19-24.

STRANGUETTI, V.; TARODA-RANGA, N. Levantamento florístico das espécies vasculares da floresta estacional mesófila semidecídua da Estação Ecológica de Paulo de Faria - SP. Revista Brasileira de Botânica, v.21, n.3, p.289298, 1998.

TORRES, R.B. Estudos florísticos e mata secundária Estação Ecológica de Angatuba, SP. Campinas, 1989. 231p. Dissertação (Mestrado) - Instituto de Biologia, Universidade Estadual de Campinas. 
TORRES, R.B., MARTINS, F.R.; KINOSHITA, L.S. Climate, soil and tree flora relantionships in forests in the state of São Paulo, southeastern Brasil. Revista Brasileira de Botânica, v.20, n.1, p.41-49, 1997.

VELOSO, H.P. Os grandes clímaces do Brasil. Memórias do Instituto Oswado Cruz, v.60, n.2, p.175-194, 1962.

VELOSO, H.P.; KLEIN, R.M. As comunidades e associações vegetais da mata pluvial do Sul do Brasil. I. As comunidades do municipio de Brusque, Estado de Santa Catarina. Sellowia, v.9, p.81-235, 1957.

VELOSO, H.P.; KLEIN, R.M. As comunidades e associações vegetais da mata pluvial do Sul do Brasil. II. Dinamismo e fidelidade das espécies em associações do Município de Brusque, Estado de Santa Catarina. Sellowia, v.10, p.9-124, 1959.

VELOSO, H.P.; KLEIN, R.M. As comunidades e associações vegetais da mata pluvial no Sul do Brasil. III. As associações das planícies costeiras do quaternário, situadas entre o rio Ipojuca (Estado de Santa Catarina) e a Bacia de Paranaguá (Estado do Paraná). Sellowia, v.13, p.205-260, 1961.

VICTOR, M.A.M. A devastação florestal. São Paulo: Sociedade Brasileira de Silvicultura, 1975. 49p.

VIEIRA, M.G.L.; MORAES, J.L.; BERTONI, J.E.A.; MARTINS, F.R.; ZANDARIN, M.A. Composição florística e estrutura fitossociológica da vegetação arbórea do Parque Estadual de Vassununga, Santa Rita do Passa Quatro (SP). II Gleba Capetinga Oeste. Revista do Instituto Florestal, v.1, n.1, p.135-159, 1989. 